\title{
New findings of ancient Greek silver sources
}

Markos Vaxevanopoulos ${ }^{1 *}$, Janne Blichert-Toft ${ }^{1}$, Gillan Davis $^{2}$, Francis Albarède ${ }^{1}$

${ }^{1}$ Ecole Normale Supérieure de Lyon, CNRS, and Université de Lyon, France

${ }^{2}$ Australian Catholic University, Sydney, Australia

*Corresponding author: Markos Vaxevanopoulos (Markos.vaxevanopoulos@ens-lyon.fr)

10

\section{Introduction}

Understanding metal production and circulation in antiquity is directly related to our

\begin{abstract}
Over the last 60 years, much analytical research has sought to determine the ore sources of ancient Greek silver artefacts. Lead isotopic analysis has played a key role in this endeavor. While most studies so far have limited their search to places mentioned in historical sources, the present study takes a different approach by first identifying Ag-bearing ore sources in the Aegean world based on their geological characteristics and then using Pb isotopes to determine whether they were exploited in antiquity. To this end, we have geolocated, sampled, and measured high-precision Pb isotopic compositions of 17 Ag-bearing mineralizations in Greece for which we have evidence of ancient mining activity, and a further 10 exhibiting minor Ag occurrences that may also have been exploited in ancient times. We found that $\mathrm{Pb}$ model ages provide better discrimination of ore sources than the more conventional plots of raw $\mathrm{Pb}$ isotope data.
\end{abstract}

Our study establishes Lavrion, northeast Chalkidiki, Pangaeon, Thasos, Siphnos, Palaea Kavala, Angistron, and south Euboea as the most important ancient silver mining districts in Greece. Two previously undiscovered ancient mining areas in Pelion and in the Kroussia mountain range are also documented. The latter may be identified with ancient Mount Dysoron, from which King Alexander I of Macedon reportedly extracted the fabulous sum of a talent of silver per day. For the first time, we isotopically differentiate some of the mining districts in Thraco-Macedonia, and show that the mines of Thasos include geologically different silver-bearing ore sources. We further identify the hitherto unrealized importance of Euboean silver mines and demonstrate that they isotopically overlap those of Siphnos, with major implications for our understanding of ancient Greek history. knowledge of ore sources, but, for the most part, these are uncertain. The main reasons for these uncertainties directly related to the primary tool used to track ore sources, namely $\mathrm{Pb}$ isotopes. First and foremost, similar $\mathrm{Pb}$ isotopic compositions can be found in more than one locality, especially if provenance is determined exclusively with the help of two-dimensional $\mathrm{Pb}$ isotope plots. Coincidence in full-fledged three-dimensional space is required to robustly establish a source (Albarède et al., 2020). Other reasons are the analytical quality of the $\mathrm{Pb}$ isotope data, the mineralogy of the ore in question (e.g. galena, chalcopyrite), and the nature 
of the object (e.g. artefact, slag) used to represent a given locality. Lead isotopic analysis (LIA) has long been widely used for $\mathrm{Pb}-\mathrm{Cu}$-Ag-bearing ore deposits to assign provenances to copper/lead/silver artefacts as it has proved to be the most reliable analytical technique for providing coherent provenance signatures, especially in coin provenance studies (Gentner et al., 1978; Gale, 1979; Chamberlain and Gale, 1980; Gale et al., 1980; Wagner et al., 1980; Wagner and Weisgerber, 1985; Artioli et al., 2020; Killick et al., 2020). During the 1960s, sampling and $\mathrm{Pb}$ isotopic measurement established $\mathrm{Pb}$ isotopic signatures for some major ancient mining districts including Lavrion (in Attica, Greece), Asia Minor, southern Iberia (Spain), and Roman Britain (Brill and Wampler, 1965; 1967; Grögler et al., 1966). A major study of Greek ore deposits published by Gale et al. (1980) for Lavrion, the Cyclades, and northern Greece, as well as many silver coinages, using different $\mathrm{Pb}$ isotopic ratios has underpinned most subsequent historical understandings of silver extraction and usage in archaic Greek coin production.

55 The identification of ancient metal sources is based on the study of ancient mining territories and sampling of the related mineralizations combined with the study of the archeometallurgical remains and applied metallurgical processes. Provenance studies using LIA may encounter problems such as mixing during smelting, cupellation, or refining (though unlikely for small operations), as well as isotopic overlap between different ore deposits. Nevertheless, LIA is a powerful tool for excluding a given ore district as a raw silver-lead provider (Stos-Gale and Gale, 2009). To help avoid erroneous source assignments using LIA, complementary archeological evidence obtained from mining/metallurgical operations and artefacts should be taken into consideration as well. However, the exact periods of ancient exploitation may be difficult to establish as it is not always possible to find archeologically datable material in a mine. Additionally, long-lasting exploitation poses interpretative difficulties because subsequent mining activity has often superimposed and hence obliterated earlier mining phases - an acute problem especially for Lavrion and Siphnos.

In this study, we first geolocated the Ag occurrences in Greece and obtained samples from those areas where the archaeological and geological features indicate the existence or likelihood of ancient mining (Fig. 1). Our approach relies on understanding the geological processes that determine where silver ores could have formed, rather than reckoning with largely anecdotal information provided by ancient writers that has happened to survive. The geological context of Greece can be described as the subduction of the African (tectonic) plate under continental Europe over the last 200 million years. During this period, convergence, obduction, collision, and subduction of geotectonic units, nappe stacking, slab retreats, and tearing processes constituted the main compounds of the geotectonic processes in the Aegean (Pe-Piper and Piper, 2002; Schmid et al., 2008; Jolivet and Brun, 2010; Jolivet et al., 2013; Menant et al., 2016; Schmid et al., 2020). Numerous Ag-bearing mineralizations in Greece are associated with intrusion-related veins, skarns, carbonate replacements, and epithermal systems (Melfos and Voudouris, 2017; Voudouris et al., 2019, Ross et al., 2020). The different types of Ag occurrences located mainly in the Rhodope massif, the SerboMacedonian zone, the Circum-Rhodope Belt, and the Attic-Cycladic crystalline complex are listed in Table 1 and shown in Fig. 2. Further information on the geotectonic evolution of Greece and its relationship with mineralizations found in ancient mining areas, as well as detailed descriptions of the archaeological settings, are included in the supplementary material (Appendix I-II).

Following this first step which underpins our sample selection, we undertook a broad, highprecision, $\mathrm{Pb}$ isotopic survey of the ores found at ancient mining localities in Greece with the 
expectation that improved state-of-the-art analytical quality would help associate Ag-bearing ores with metal use. The acquired high-precision $\mathrm{Pb}$ isotope data were used to calculate $\mathrm{Pb}$ model ages' using the parameters of Albarède and Juteau (1984) and the equations of Albarède et al. (2012). The advantage of $\mathrm{Pb}$ model ages is that they define ore provenance better than conventional two-dimensional plots of unprocessed (raw) $\mathrm{Pb}$ isotopic ratios by supplying additional information and clarity. Lead model ages establish the geological age of initial $\mathrm{Pb}$ segregation from the crustal source to form the ore precursor. The $\mathrm{U} / \mathrm{Pb}(\mu)$ and $\mathrm{Th} / \mathrm{U}(\kappa)$ ratios, also deduced from the measured $\mathrm{Pb}$ isotopic abundances of the ores, constitute two additional sensitive parameters characteristic of their crustal source (Albarède et al., 2012; 2021). Lead model ages tend to be distributed in well-defined frequency peaks which represent a useful and strongly visual tool (Milot et al., in press). By contrast, plots of conventional raw $\mathrm{Pb}$ isotopic ratios normalized to ${ }^{204} \mathrm{~Pb}$ show strong correlations which obscure the true data relationships. This correlation is due to the much larger statistical noise on the small ${ }^{204} \mathrm{~Pb}$ peak with respect to the peaks of the other more abundant $\mathrm{Pb}$ isotopes. Correlation coefficients were calculated by Albarède et al. (2004) and are approximately 0.94 in ${ }^{207} \mathrm{~Pb} /{ }^{204} \mathrm{~Pb}$ versus ${ }^{206} \mathrm{~Pb} /{ }^{204} \mathrm{~Pb}$ plots and 0.96 in ${ }^{208} \mathrm{~Pb} /{ }^{204} \mathrm{~Pb}$ versus ${ }^{206} \mathrm{~Pb} /{ }^{204} \mathrm{~Pb}$ plots, which are statistically highly significant. Slanted, narrow elliptic error surfaces in two-dimensional space (such as those commonly used for U-Pb dating) and ellipsoidal volumes in threedimensional space therefore are more appropriate than the simple 'error boxes' often used in LIA. To give an example (e.g. Artioli et al., 2020; Wind et al., 2020), in a plot of ${ }^{207} \mathrm{~Pb} /{ }^{204} \mathrm{~Pb}$ versus ${ }^{206} \mathrm{~Pb} /{ }^{204} \mathrm{~Pb}$, or, as would be the case in another plot also widely used in archaeometry, ${ }^{208} \mathrm{~Pb} /{ }^{206} \mathrm{~Pb}$ versus ${ }^{207} \mathrm{~Pb} /{ }^{206} \mathrm{~Pb}$, different groups of points overlap to some extent. In addition to better error treatment as outlined above, improving the overall analytical quality of $\mathrm{Pb}$ isotopic data will be certain to enhance provenance resolution. Moreover, as will be shown in this paper, a one-dimensional $T_{\text {mod }}$ histogram based on the new high-precision $\mathrm{Pb}$ isotope data from this study shows several well-defined peaks, which, when compared to the broader peaks based on older, often less precise literature data, confirms the necessity of focusing on data collected with modern quality standards, in particular those acquired by MC-ICP-MS for which analytical mass bias is well controlled.

\section{Materials and Methods}

120 We have identified 44 Ag-rich mineralizations in Greece (Table 1). Of these, we obtained samples from 17 for which we could find evidence of ancient mining activity (Fig. 1). We sampled another 10 districts with minor Ag occurrences where no proven ancient mining activity, but for which, based on the local geology, it seems a reasonable possibility that future archeological research may uncover such evidence. These areas present sparse and unidentified mining traces, such as from chisel and pick, that might date to antiquity, but pottery or organic material that could provide reliable dating are absent. In some cases, modern exploitation has obliterated probable ancient mining phases. The remaining 17 minor $\mathrm{Ag}$ ore deposits with no evidence or geological likelihood of ancient mining were not sampled and are not described in the present study. The field investigations were conducted from March to July 2019, and from June to July 2020.

Silver and $\mathrm{Pb}$ concentrations and $\mathrm{Pb}$ isotopic compositions of 149 samples from the above mentioned mineralizations were analyzed by, respectively, quadrupole inductively-coupled plasma mass spectrometry (Q-ICP-MS) and multiple-collector inductively-coupled plasma mass spectrometry (MC-ICP-MS) at the Ecole Normale Supérieure in Lyon (ENS Lyon). 
Further information on sample preparation, analytical techniques, and accuracy and precision can be found in the supplementary material (Appendix III). The geological characteristics, latitude and longitude, $\mathrm{Ag}$ and $\mathrm{Pb}$ concentrations, $\mathrm{Pb}$ isotopic compositions, $\mathrm{Pb}$ model ages $T_{\text {mod, }}$, and apparent ${ }^{238} \mathrm{U} /{ }^{204} \mathrm{~Pb}(\mu)$ and ${ }^{232} \mathrm{Th} /{ }^{238} \mathrm{U}(\kappa)$ values are listed in Table 2.

Lead model ages $\left(T_{\mathrm{mod}}\right)$ (Table 2$)$ were calculated from the measured $\mathrm{Pb}$ isotopic 140 compositions according to Albarède and Juteau (1984) and would differ by $30 \mathrm{Ma}$ at most from those calculated from the parameters of Stacey and Kramer (1975) but have the advantage of eliminating most negative values. The values of $\mu\left({ }^{238} \mathrm{U} /{ }^{204} \mathrm{~Pb}\right)$ and $\kappa\left({ }^{232} \mathrm{Th} /{ }^{238} \mathrm{U}\right)$ also were computed (Table 2) from the measured $\mathrm{Pb}$ isotopic compositions. Table 3 lists $\mathrm{Pb}$ isotopic data from previous studies of Greek $\mathrm{Pb}-\mathrm{Zn}$ mineralizations, which have been used in this paper though they are, in general, less precise that the $\mathrm{Pb}$ isotopic data acquired in the present study. Data on slags, litharge, and copper mineralizations were not included.

\section{Results and discussion}

\subsection{On-site investigation and Ag grades of ancient Aegean mining districts}

150 Field observations of ancient mining territories allow (i) the documentation of the extent of mining activity, (ii) to distinguish between different exploitation phases, (iii) to record the extent of the metallurgical processes, and (iv) to evaluate the relative importance of each mining area (Table 4). In the following, the investigated mining districts are described according to their geological context and their archeological importance. Silver yields are also summarized in Table 2.

\subsubsection{Attic-Cycladic Core Complex (central Greece and southern Aegean)}

Lavrion. Mining galleries span kilometers of underground workings with $>2 \mathrm{~km}$ in the Esperanza mine in east Kamareza (Fig. 3a). The exploitation is extensive at the numerous mantos (horizontal) Ag occurrences mainly in the Kamaresa, Souresa, Botsari, and Ari areas. The Plaka area presents numerous modern exploitation adits, but only scarce remains of ancient mines are found at the surface. The ancient mining areas closest to the Plaka granodiorite are at Ari and Dimoliaki with numerous adits and shafts that explore the contact between the Lavrion schists and Pounta marble (Fig. 3b). The Sounion area has shafts and ancient mines at the south edge of the Lavreotiki. The consistently high Ag yields reveal the importance of Lavrion with Ag concentrations varying from 1673 ppm in Kamareza to 5872 ppm in the modern mines of Plaka. A galena sample (L-17) found at the metallurgical area of Poundazeza (southeast coast of Lavrion) has a Ag concentration of $4220 \mathrm{ppm}$, which is representative of the ores being processed at the metallurgical areas.

Mount Hymettus. Situated to the east of Athens, the mountain hosts argentiferous galena veins (Stouraiti et al., 2019) exploited by three modern adits and a shaft in Agios Ioannis Kynigos and two adits in the Kamini area. No ancient mining has been recorded in the underground exploitations. Concentrations of $\mathrm{Ag}$ are low (0 to $6.3 \mathrm{ppm}$ ), whereas Stouraiti et al. (2019) mentions Ag concentrations from 6 to $>1500 \mathrm{ppm}$.

South Euboea. There are three Ag-bearing ore districts: the Kallianou valley, the Schinodavli site escarpment in the Agios Dimitrios gorge, and the Gialpides gorge. Mining activity and prospecting are recorded at the Kallianou valley with 11 modern adits and two ancient workings. The Ag concentration in a galena sample from the ancient Moskies mine in Kallianoi is $730 \mathrm{ppm}$. The most significant mine of the Gialpides gorge is located near the 
shore with almost $500 \mathrm{~m}$ of underground galleries (Fig. 3c). Pottery from the Classical period is found in the inner part of the mine. An extensive, but poorly investigated, metallurgical area at the Archampolis settlement in south Euboea (Keller, 1984) suggests that south Euboea should be considered an important ancient mining area which has been largely, if not totally, ignored in discussions of ancient Greek silver sources.

Central Euboea. There is one minor Ag occurrence in the Almyropotamos mining district comprising three modern shafts and two horizontal galleries with scarce traces of ancient mining. Supergene alteration of the mineralization is major at its higher levels. The supergene mineralization contains 75-91 ppm Ag.

Siphnos. The central part of the island has five mining subdistricts with ancient galleries at Agios Sostis, Agios Sylvestros, Voreini, Kapsalos-Frase, and Xero-Xylo (Fig. 3d, e)

190 exploiting the Ag-rich mineralization pods from the carbonate replacement bodies in marbles. Other mines in the southern part of the island contain very low-grade $\mathrm{Ag}$ ore. Wagner and Weisgerber (1985) documented prehistoric ( $3^{\text {rd }}$ mil. BC), Archaic-Classical (5-4 ${ }^{\text {th }}$ cent. BC), and modern mining $\left(19-20^{\text {th }}\right.$ cent. $\left.\mathrm{AD}\right)$ in Siphnos. Roman and Byzantine pottery was found at the surface of the mining areas of Kapsalos-Frase and Xero-Xylo. Iron-manganese

195 exploitation during the $19^{\text {th }}$ and $20^{\text {th }}$ centuries has obliterated most ancient traces at Agios Sylvestros, Kapsalos, Frase, and Xero-Xylo, while Voreini has been converted to a landfill. The mineralization from the ancient district of Agios Sylvestros contains high concentrations of Ag up to 4983 ppm.

Seriphos. Nine modern adits with parts testifying to ancient exploitation exist in the Moutoula area in the northern part of the island (Fig. 3f). The mines explore the Ag-rich vein system in the schist-marble intercalations. The mineralization contains 161-470 ppm Ag.

Melos. Two ancient open works were discovered on the island in Triades and one ancient adit at Katsimouti beach. In Triades, Ag concentrations in the galena reach 2473 ppm.

Syros. Silver-rich sulphides are found as disseminations and massive sulfide bodies along the marbles and schists with the most representative ore district being Rozos, an ancient mine with prehistoric rock tools in its interior with high $\mathrm{Pb}-\mathrm{Zn}-\mathrm{Cu}-\mathrm{Ag}$ contents. The $\mathrm{Ag}$ concentrations in galena vary from 1 to $26 \mathrm{ppm}$. Ores with higher grades ( 25 to $>100 \mathrm{ppm}$ ) are documented in Azolimnos (Voudouris et al., 2014).

Kythnos. In Agios Dimitrios, at the southern edge of the island, $\mathrm{Pb}$ mineralization takes place mainly as galena. Ancient galleries of limited length in low-grade (0.2-16.2 ppm) Ag-bearing veins were discovered near the shore of Agios Dimitrios and near the acropolis of Kastellas (Fig. 3g).

Antiparos. Quartz veins in the gneisses and schists at the central and western parts of the island host Ag-bearing mineralizations (2-386 ppm). In the inner parts of modern mines in the Monastiria area, undatable older mining phases have been recorded.

Polyaigos. Modern mining activity was recorded in Ba-rich veins, but ancient traces are absent. The veins contain Ag up to 116 ppm.

Anaphi. Modern mining is located at the central-south part of Anaphi. The Ag concentration is $81 \mathrm{ppm}$. 
Pelion. Ancient mines with Ag-bearing mineralizations are documented here for the first time. Numerous mineralized veins occur at the Pelion tectonic window (Attic-Cycladic Massif) from Zagora to Ksourichti village. Two ancient mines were discovered in Tsagarada and Ksourichti villages, respectively (Fig. 3h). They exploited low-grade Ag veins (3-13 ppm).

\subsubsection{Rhodope Massif-Serbo-Macedonian Zone-Circum Rhodope Belt (northern Greece and} northern Aegean islands)

Northeast Chalkidiki. The Olympiada mining subdistrict of northeast Chalkidiki comprises several ancient mining shafts and horizontal mines which were used to exploit Ag-rich veins (14.2-2879.6 ppm) (Fig. 3i). At the Madem Lakkos, Mavres Petres, and Stratoni areas, modern mining activity may have obliterated older phases of exploitation.

Thasos. The Acropolis mine, next to the ancient fortification of Thasos, constitutes the island's most significant ancient exploitation of Ag-bearing veins (Fig. 3j) The mine has 1226 $\mathrm{m}$ of underground galleries. The mineralizations are rich in $\mathrm{Pb}, \mathrm{Zn}$, and $\mathrm{Cu}$ and contain $\mathrm{Ag}$ up to $945 \mathrm{ppm}$ and Au up to $60.9 \mathrm{ppm}$. Modern exploitation of Fe-Mn-Zn-rich mineralizations has presumably destroyed ancient mining traces at areas such as Vouves and Mavrolakas.

Kroussia. This ancient mining district was discovered during the present study. At Koulachli in the northeast, a number of ancient mines were investigated which exploited Ag ore hosted in veins that crosscut the schist (Fig. 3k). The Ag-bearing mineralization at the Agios Markos area contains up to $1364 \mathrm{ppm} \mathrm{Ag}$. Field observations such as the existence of several ancient mines together with the high Ag concentrations point to the importance of the Kroussia mining area. Its location plausibly allows it to be identified as ancient Dysoron, situated on the eastern borders of the kingdom of Macedon under Alexander I (Xydopoulos, 2016). It was mentioned by Herodotus (5.17) as providing the king with the huge sum of a talent of silver per day.

245 Angistron. Two extended mines in the Lechovo subdistrict were recorded. The exploitation followed the carbonate replacement voids and the veins in the marbles filled with oxidized mineralization. Pottery found in the inner parts of the ancient mines dates to the Hellenistic and Roman periods. The ore contains up to $182 \mathrm{ppm} \mathrm{Ag.}$

Pangaeon. Asimotrypes is the most extended mining system on Mount Pangaeon and comprises eight ancient galleries (Fig. 31). The concentration of Ag is higher than any other ancient Greek mining district (up to 9906 ppm).

Palaea Kavala. An extensive mining area with horizontal adits and vertical shafts (Fig. 3m) mentioned in the literature (Koukouli-Chrysanthaki, 1990; Vavelidis et al., 1996) as the ancient "Scapti Yli". Roman pottery is abundant at the surface of most galleries. The 255 analyzed samples from Palaea Kavala contain from 57 to $213 \mathrm{ppm} \mathrm{Ag.} \mathrm{The} \mathrm{extent} \mathrm{of} \mathrm{the}$ underground works suggests it was a very important mining area for gold and silver which has so far been underestimated.

Lesbos. Modern adits are found at the northern part of Lesbos in the Megala Therma area close to Argenos village. Ancient narrow galleries and shafts have been recorded in the inner part of the modern adits (Pernicka et al., 2003), but during the present study only modern mining activity was documented. The Ag concentration is $154 \mathrm{ppm}$. 
Rhodope mountain range. Thermes, Sappes, Neda, Aisymi, and Pefkos have low-grade concentrations of Ag except for the Kirki ore deposit. The epithermal deposits of Sappes, Neda, Aisymi, and Pefkos contain up to $66 \mathrm{ppm}$ Ag The carbonate replacement system in Thermes is characterized by similarly low Ag concentrations (4-52 ppm). Although the Kirki area has Ag-rich mineralizations (97-1044 ppm), no signs of ancient mining activity have been found there or in the neighboring areas. Modern mining has taken place in Kirki, and modern prospection trenches and adits exist in Aisymi, Sappes, and Neda. One sample from the epithermal vein system in south Samothrace island contains $471 \mathrm{ppm} \mathrm{Ag.} \mathrm{Modern}$ prospecting galleries are found in the island.

\subsection{Lead isotope analysis}

The $\mathrm{Pb}$ isotopic compositions of the 149 galena, cerussite, and anglesite samples from the 27 Ag-bearing mineralizations in Greece investigated here are listed in Table 2. Table 3 lists the relevant literature data (Barnes et al., 1975; Gale and Stos-Gale, 1981a; Wagner and Weisgerber, 1985; Wagner et al., 1986; Kalogeropoulos et al., 1989; Nebel et al., 1991; Frei, 1992; Stos-Gale et al., 1996; Gale, 1998; Asderaki et al., 2017; OXALID and IGME unpublished data). Comments on the existence of ancient mining activity for each Ag-bearing mineralization based on field investigations and literature also are provided.

We first focus on the results of the present work. Figure 4 shows the standard plots of ${ }^{207} \mathrm{~Pb} /{ }^{204} \mathrm{~Pb}$ (a) and ${ }^{208} \mathrm{~Pb} /{ }^{204} \mathrm{~Pb}$ (b) versus ${ }^{206} \mathrm{~Pb} /{ }^{204} \mathrm{~Pb}$, and ${ }^{208} \mathrm{~Pb} /{ }^{206} \mathrm{~Pb}$ versus ${ }^{207} \mathrm{~Pb} /{ }^{206} \mathrm{~Pb}$ (c). $\mathrm{T}_{\text {mod }}\left(\mathrm{Pb}\right.$ model age) is plotted versus $\mu\left({ }^{238} \mathrm{U} /{ }^{204} \mathrm{~Pb}\right)$ and $\kappa\left({ }^{232} \mathrm{Th} /{ }^{238} \mathrm{U}\right)$ in Fig. $4 \mathrm{~d}$ and $4 \mathrm{e}$, respectively. Figure 5 also displays the raw $\mathrm{Pb}$ isotope ratios but in map view: ${ }^{206} \mathrm{~Pb} /{ }^{204} \mathrm{~Pb}(\mathrm{a})$, ${ }^{207} \mathrm{~Pb} /{ }^{204} \mathrm{~Pb}(\mathrm{~b}),{ }^{208} \mathrm{~Pb} /{ }^{204} \mathrm{~Pb}(\mathrm{c}),{ }^{207} \mathrm{~Pb} /{ }^{206} \mathrm{~Pb}(\mathrm{~d})$, and ${ }^{208} \mathrm{~Pb} /{ }^{206} \mathrm{~Pb}$ (e). The data from the southern Aegean and northern Greece are better separated in Fig. 5a-c $\left({ }^{204} \mathrm{~Pb}\right.$-normalized) than in Fig. 285 5d-e $\left({ }^{206} \mathrm{~Pb}\right.$-normalized).

Figure 6 shows maps of $T_{\text {mod }}\left(\mathrm{Pb}\right.$ model age) (a), $\mu\left({ }^{238} \mathrm{U} / 204 \mathrm{~Pb}\right)(\mathrm{b})$, and $\kappa\left({ }^{232} \mathrm{Th} /{ }^{238} \mathrm{U}\right)$ (c) for the new data of the present study. Except for a few Upper Devonian ages, the $\mathrm{Pb}$ model ages calculated for Aegean localities cluster in groups from the Jurassic to the present as observed on the map of Fig. 6a. Although overall regional consistency is observed, the $\mathrm{Pb}$ model ages of some ores from the same island, such as Thasos, Kythnos, and Euboea show a broad range of values. The $\mathrm{Pb}$ model ages define different domains in the Aegean. The oldest $\mathrm{Pb}$ model ages are recorded in Hymettus (367-345 Ma), Samothrace (360 Ma), and MyriophytoKroussia (343 Ma), representing the oldest Ag-bearing mineralization group (Fig. 6a, Table 2). The most recent $\mathrm{Pb}$ model ages (15-3 Ma) are recorded at Agios Dimitrios on the island of 295 Kythnos. The $\mu$ values of the southern Aegean are higher than those of northern Greece (Fig. $6 b)$. The highest $\kappa$ values are more frequent in the eastern Cyclades and, in general, $\mu$ seems to have a strong potential to discriminate different mining districts (Fig. 6b, c). The crust systematically has high $\mathrm{U} / \mathrm{Pb}$ and $\mathrm{Th} / \mathrm{U}$ in the eastern relative to the western Cyclades and even more so relative to northern Greece. This difference clearly is due to subduction bringing together terranes with very different tectonic histories.

The isotopic field for Lavrion is compact (Fig. 4b, c) and easily distinguished from the fields of other ancient mining areas of Pangaeon, Thasos, Chalkidiki, Euboea, and Siphnos. Samples from the Lavrion mining subdistricts of Kamaresa, Soureza, Botsari, and Ari, and even the modern Plaka and Filoni-80 mines have similar isotopic signatures that fall within a welldefined field. Chalkidiki, Pangaeon, and Thasos overlap in most LIA plots not involving ${ }^{204} \mathrm{~Pb}$ (Fig. 4c, 5e). The geographical proximity and relative similarities in the geological setting of 
these mining districts (Rhodope Massif) lead to difficulties in distinguishing between ore clusters.

The partial overlapping of the Siphnos, Euboea, Pangaeon, Thasos, and Chalkidiki fields poses a problem for determination of provenance (Fig. 4c). The Palaea Kavala and Angistron mining districts, which here have been measured for their $\mathrm{Pb}$ isotopic compositions for the first time, overlap with Chalkidiki, Euboea, Thasos, Rhodope, and Pangaeon (Fig. 4). The $\mathrm{Pb}$ isotopic signature of the Acropolis mine in northeast Thasos is significantly different from that of the southwest Thasos Pb-Zn ores (Fig. 4). Analogous segmentation is observed for the fields of Kythnos and Euboea (Fig. 4). The present work also presents the $\mathrm{Pb}$ isotopic composition for the Kroussia mining area for the first time. Its isotopic field is close to those of Lavrion, Chalkidiki, and Thasos (Fig. 4). The ore sample D-10 was collected in the northwest part of Kroussia, deriving from a different mineralization where no mining traces have been found so far in the adjacent area. This difference is depicted in the diagrams as well as observed for the Hymettus and Samothrace samples (Fig. 4a-c). The Pb isotopic signatures of south Euboea mineralizations from Kallianoi, Gialpides, and Schinodavli are different from those of Almyropotamos situated in the center of the island (Fig. 4a-c), as a probable expression of the local tectonic complexity (Jolivet et al., 2013; Melfos and Voudouris, 2017).

\subsection{Lead model ages and other geologically informative parameters}

325 Although Fig. 5 shows regional differences in raw $\mathrm{Pb}$ isotope ratios (in particular for ${ }^{204} \mathrm{~Pb}$ normalized ratios), the differences are regionally more coherent in $T_{\bmod }-\mu-\kappa$ space, in which northern Greece and the eastern and western Cyclades form well-delineated provinces consistent with local tectonics. In most, if not all, cases, $\mathrm{Pb}$ model ages are significantly older than the corresponding emplacement ages (Tables 1 and 2) (see Milot et al., in press). Lead model ages, therefore, cannot be used to date ore deposits or their country rocks. The significance of the multiple but well-defined peaks present in the model age histogram of Fig. 7 thus must be clarified. If the peaks corresponded to different mixtures of $\mathrm{Pb}$ from the country rocks, the outcome would be much broader peaks than those observed or even no peaks at all. We will therefore adopt the straightforward model proposed by Milot et al. (in press) which states that, regardless of ore type, ore genesis involves two independent steps: (1) formation of the original $\mathrm{Pb}$ stock followed by (2) transport of this stock to its current location. Lead model ages correspond to the last $\mathrm{U} / \mathrm{Pb}$ fractionation event that formed the current $\mathrm{Pb}(-\mathrm{Zn}-\mathrm{Ag})$ stock. Whether the current deposit is magmatic, hydrothermal, epigenetic, or other is irrelevant to radiogenic $\mathrm{Pb}$ ingrowth. The petrogenesis of $\mathrm{Pb}$ ores is in many aspects reminiscent of the petrogenesis of oil fields, which has been pointed out a number of times in the literature.

We calculated Gaussian Mixture Models using the fitgmdist function of Matlab ${ }^{\mathrm{TM}}$. This function implements the iterative technique called 'Expectation Maximization' which assumes that each cluster has an independent Gaussian distribution, each with its own mean and covariance matrix. We found that a Gaussian mixture of five components provides an adequate description of the present data set. Table 5 shows the results in the $T_{\bmod }, \mu$, and $\kappa$ space for the galena samples analyzed in this work with and without literature data included. Comparison with the groups identified by Milot et al. (in press) for the Iberian Peninsula shows that the very strong Cenozoic peak ( $35 \pm 9 \mathrm{Ma})$ is absent from Iberia, where late

350 Devonian (395 $\pm 40 \mathrm{Ma}$ ) prevails. The $T_{\bmod }, \mu$, and $\kappa$ space therefore offers a potential provenance tool allowing a distinction to be made between the Aegean and the Iberian provinces on the condition that three rather than two, not even pair by pair, isotopic variables 
are used. The Early to Mid-Cretaceous $\mathrm{Pb}$ model age peak is present in both the Aegean realm

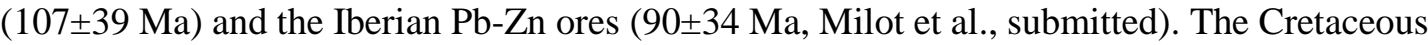
peaks are strong in both provinces, whereas the Early to Mid-Jurassic peak (190 $\pm 13 \mathrm{Ma}$ ) is subdued in both provinces.

It has long been known that $\mathrm{Pb}$ must be derived from the upper crust, such as the Cycladic basement and Cycladic Blueschist in the southern Aegean, and not from the mantle (Doe and Delevaux, 1972; Heyl et al., 1974; Leach et al., 2005; Wilkinson, 2013; Arribas and Tosdal, 1994; Wind et al., 2020). Explaining the existence of well-defined peaks of $\mathrm{Pb}$ model ages under such conditions remains a challenge. Milot et al. (in press) suggested that $\mathrm{Pb}$ was originally concentrated in marine sediments during anoxic events, whether global or more local, with sulfur being derived from volcanic activity. Because hydrothermal sulfides are quickly oxidized as sulfate in seawater, the concentration step of massive deposits is unlikely to be possible under normal oxic conditions. As for the second step, hydrothermal activity associated with magmatism or convection of basinal fluids constitute the most probable mechanisms leading to the transportation of $\mathrm{Pb}(-\mathrm{Zn}-\mathrm{Ag})$ to their current position in the crust.

The arguments presented by Milot et al. (in press) for the Iberian Peninsula to support the initial segregation of large amounts of $\mathrm{Pb}$ in sediments during anoxic events are also valid for the Cretaceous $\mathrm{Pb}$ model ages in the Aegean. The prominent peak of Cenozoic $\mathrm{Pb}$ model ages ( $35 \pm 9$ Ma; Fig. 7) is consistent with the ubiquitous accumulation of carbon-rich sediments in the Paratethys during the Oligocene in a broadly east-west trending zone extending from the Panonian Basin to the Carpathian, all the way to Azerbaidjan to a rock formation locally known as the Maikopian group (Pawlewicz, 2007; Hudson et al., 2008; Sachsenhofer et al., 2018; Shnyukov and Yanko-Hombach, 2020). The abundant Cretaceous $\mathrm{Pb}$ model ages are reflected by some geological evidence from northwestern Greece (Tsikos et al., 2004). In

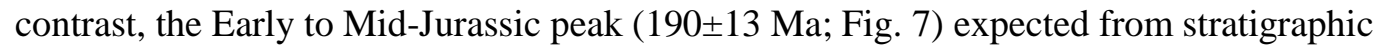
studies (e.g. Kafousia et al., 2018) is subdued.

\subsection{A remark on overlapping fields}

380 Possible ambiguities created by fields overlapping in two-dimensional plots, such as ${ }^{207} \mathrm{~Pb} /{ }^{204} \mathrm{~Pb}$ versus ${ }^{206} \mathrm{~Pb} /{ }^{204} \mathrm{~Pb}$, and sometimes in two of such paired plots at the same time, should not be overemphasized. Cases for which groups of data plotted in the threedimensional ${ }^{206} \mathrm{~Pb} /{ }^{204} \mathrm{~Pb}-{ }^{207} \mathrm{~Pb} /{ }^{204} \mathrm{~Pb}-{ }^{208} \mathrm{~Pb} /{ }^{204} \mathrm{~Pb}$ space overlap on their projections onto two 'faces' of the coordinate system, while defining separate volumes in three dimensions, are easy to conceive and visualize. The same situation is also conceivable in the threedimensional $\mathrm{T}_{\bmod }-\mu-\kappa$ space. Use of three-dimensional plots to represent $\mathrm{Pb}$ isotope data is unfortunately uncommon in archeometry (Albarède et al., 2020). In practice, such ambiguities rarely arise in three dimensions as three-dimensional fields, or volumes, rarely overlap. An efficient 'convex hull' technique to assess provenance issues in threedimensional $\mathrm{Pb}$ isotope space is described by Gentelli et al. (submitted).

\section{Conclusions}

Field observations made during this study have led to the conclusion that the most significant ancient Ag mining territories in the Aegean were Lavrion, northeast Chalkidiki, Pangaeon mountain, the islands of Siphnos, Thasos and Euboea, Palaea Kavala, Kroussia, and the Angistron district. This significantly broadens the mining areas from which ancient peoples 
extracted silver beyond those specifically attested to in ancient sources and deduced from numismatic considerations. High Ag concentrations in samples from Lavrion (5872 ppm), Chalkidiki (2880 ppm), Pangaeon (9906 ppm) and Siphnos (4983 ppm) are indicative of the importance of these deposits, while the galena sample found at the Poundazeza metallurgical area in Lavrion with $4220 \mathrm{ppm} \mathrm{Ag}$ provides information about what was considered to be profitable yields, though mines with lower yields were also exploited possibly as extraction techniques improved in Hellenistic and Roman times.

We have provided new high-precision $\mathrm{Pb}$ isotopic data from samples obtained from the known ancient mining territories in Greece with the intention of providing a useful tool for silver artefact provenance studies. A clear distinction in $\mathrm{Pb}$ isotopic composition is observed between the major silver mining territories in the Aegean, such as Lavrion and SiphnosPangaeon-Thasos-Chalkidiki. Samples originating from proximate and geologically relevant areas, such as Pangaeon, Thasos, and Chalkidiki, overlap to some extent in lead isotopic plots. We further demonstrate that combining plots of raw $\mathrm{Pb}$ isotope ratios with calculated $\mathrm{Pb}$ model ages provides more reliable provenance assessment.

An important finding is that the measured $\mathrm{Pb}$ isotopic variations and calculated $\mathrm{Pb}$ model ages from some closely neighboring mining areas, especially on islands such as Thasos, Kythnos, and Euboea, may sometimes reveal different $\mathrm{Pb}$ sources. Thus, northeast Thasos differs from southwest Thasos, north-central Kythnos differs from southwest Kythnos, and south Euboea differs from Almyropotamos (central Euboea).

In contrast to the older, generally more noisy literature data, the $\mathrm{Pb}$ model age histogram of the new high-precision $\mathrm{Pb}$ isotope data of this study shows well-defined peaks which further enhance the resolution of provenance assignment. This observation is consistent with that of

420 Milot et al. (in press) for Iberian ores. Lead model ages do not date the formation of the present ore deposits as the two sets of ages are distinctly different, with $\mathrm{Pb}$ model ages being systematically older than ore emplacement ages. Regardless of ore type, the isotopic data can be accounted for by a two-stage evolution model, much reminiscent of that of oil-field formation. The first stage accounts for $\mathrm{Pb}$ accumulation in sediments during global or local 425 anoxic events, while the second stage corresponds to the remobilization of the original $\mathrm{Pb}$ stocks by basinal and metamorphic fluids.

Another important finding is that, until now, ores from Euboea have been neglected in provenance studies but may have contributed more substantially to coinage production than currently realized, especially in the late Archaic period for the island of Aegina, considered to be the earliest Greek minter outside of Asia Minor (Stos-Gale and Davis, 2020).

Likewise, evidence of extensive ancient exploitation from Palea Kavala and exceptionally high Ag yields from Pangaeon (Asimotrypes) in northern Greece suggest that these districts have been underestimated as mining sources, while low yields from the Rhodope mountain range suggest it has been overestimated.

435 Finally, field investigations combined with $\mathrm{Pb}$ isotopic data have revealed two so-far undiscovered ancient mining areas in the Mounts Pelion and Kroussia. The geographic location of the mining district in Kroussia and the characteristics of the Ag-bearing mineralization allow it to be plausibly identified with Mount Dysoron described as a silverrich area during Alexander's I reign (Hdt. 5.17). 


\section{Acknowledgements}

This work was funded by the European Research Council H2020 Advanced Grant 741454SILVER-ERC-2016-ADG 'Silver isotopes and the rise of Money' awarded to Francis Albarède. The Archaeological Ephorates of the East Attica Cyclades, Euboea, Magnesia, Chalkidiki, Kilkis, Serres, Kavala, and Thasos (Greek Ministry of Culture) kindly gave permission to conduct the fieldwork and ore sampling carried out during this study. Pavlos Tsitsanis, exploration manager of Eldorado Gold Corporation, is gratefully acknowledged for providing galena samples. We thank Philippe Télouk, Jean Milot, and Chloé Malod-Dognin for help with the mass spectrometers and Vasilis Melfos, Panagiotis Voudouris, and James

450 Ross for facilitating sampling by sharing their knowledge and experience. Fieldwork assistance by Zacharoula Papadopoulou, Anna Aslanoglou, Kyriaki Fellachidou, and numerous local people in the ancient mining areas of Greece is also gratefully acknowledged.

\section{References}

Albarède, F., Juteau, M., 1984. Unscrambling the lead model ages. Geochim. Cosmochim. Acta 48,207-212. https://doi.org/10.1016/0016-7037(84)90364-8

Albarède, F., Telouk, P., Blichert-Toft, J., Boyet, M., Agranier, A., Nelson, B., 2004. Precise and accurate isotopic measurements using multiple-collector ICPMS, Geochim. Cosmochim. Acta 68, 2725-2744.

Albarede, F., Desaulty, A.M., Blichert-Toft, J., 2012. A geological perspective on the use of $\mathrm{Pb}$ isotopes in Archaeometry, Archaeometry 54, 853-867.

Albarède, F., Blichert-Toft, J., Gentelli, L., Milot, J., Vaxevanopoulos, M., Klein, S., Westner, K., Birch, T., Davis, G., de Callataÿ, F., 2020. A miner's perspective on $\mathrm{Pb}$ isotope provenances in the Western and Central Mediterranean, Journal of Archaeological Science 121, 105194.

Albarède, F., Blichert-Toft, J., de Callatä̈, F., Davis, G., Debernardi, P., Gentelli, L., Kemmers, F., Klein, S., Malod-Dognin, C., Milot, J., Telouk, P., Vaxevanopoulos, M., Westner, K. 2021. From commodity to money: The rise of silver coinage around the Ancient Mediterranean (sixth-first centuries bce). Archaeometry, 63(1), 142-155. https://doi.org/10.1111/arcm.12615

Alfieris, D., Voudouris, P., Spry, P. G. 2013. Shallow submarine epithermal $\mathrm{Pb}-\mathrm{Zn}-\mathrm{Cu}-\mathrm{Au}-$ Ag-Te mineralization on western Milos Island, Aegean Volcanic Arc, Greece:

Mineralogical, geological and geochemical constraints. Ore Geology Reviews, 53, 159180.

475 Arribas, A., Tosdal, R.M. 1994. Isotopic composition of $\mathrm{Pb}$ in ore-deposits of the Betic Cordillera, Spain - Origin and relationship to other European deposits. Economic Geology 89, 1074-1093.

Artioli, G., Canovaro, C., Nimis, P., Angelini, I. 2020. LIA of prehistoric metals in the central mediterranean area: A review. Archaeometry, 62, 53-85. 
bronze metalwork. STAR: Science \& Technology of Archaeological Research, 3(2), pp.179-193.

Barnes, I. L., Shields, W. R., Murphy, T. J., Brill, R. H. 1975. Isotopic analysis of Laurion lead ores.

Bassiakos, Y., Philaniotou, O. 2007. Early copper production on Kythnos: archaeological evidence and analytical approaches to the reconstruction of metallurgical process. Metallurgy in the early bronze age Aegean, 7, 19.

Brill, R.H., Wampler, J.M. 1965. September. Isotope ratios in archaeological objects of lead. In Application of science in examination of works of art. Proceedings of the seminar: September 7-16, 1965 (pp. 155-166).

Brill, R.H., Wampler, J.M. 1967. Isotope studies of ancient lead. American Journal of Archaeology, 71(1), pp.63-77.

Bonsall, T.A., Spry, P.G., Voudouris, P.C., Tombros, S., Seymour, K.S., Melfos, V. 2011. The geochemistry of carbonate-replacement $\mathrm{Pb}-\mathrm{Zn}-\mathrm{Ag}$ mineralization in the Lavrion district, Attica, Greece: Fluid inclusion, stable isotope, and rare earth element studies. Economic Geology, 106(4), pp.619-651.

Chamberlain, V, Gale N. H. 1980. The isotopic composition of lead in Greek coins and in galena from Greece and Turkey. In: Slater EA, Tate JO (eds) Proceedings of the 16th International Symposium on Archaeometry and Archaeological Prosepection, Edinburgh 1976. The National Museum of Antiquities of Scotland, pp 139-155.

Chiotis, E., Koukouzas, C., Papadimitriou, G. 1996. Old mining and metallurgical activities in Angistron-Serres-Macedonia. In Proceedings of the 2nd Symposium of the Hellenic Archaeometric Society (pp. 77-89). Hellenic Archaeometric Society Thessaloniki.

Conophagos, C.E. 1980. Le Laurium antique: et la technique Grecque de la production de l'argent (Athens).

Doe, B.R., Delevaux, M.I.-I. 1972. Source of Lead in Southeast Missouri Galena Ores'. Econ. Geol. 67, 409-425.

Ducoux, M., Branquet, Y., Jolivet, L., Arbaret, L., Grasemann, B., Rabillard, A., Gumiaux, C., Drufin, S. 2017. Synkinematic skarns and fluid drainage along detachments: The West Cycladic Detachment System on Serifos Island (Cyclades, Greece) and its related mineralization. Tectonophysics, 695, pp.1-26.

Fornadel, A. P., Spry, P. G., Melfos, V., Vavelidis, M., Voudouris, P. C. 2011. Is the Palea Kavala $\mathrm{Bi}-\mathrm{Te}-\mathrm{Pb}-\mathrm{Sb} \pm \mathrm{Au}$ district, northeastern Greece, an intrusion-related system?. Ore Geology Reviews, 39(3), 119-133.

Frei, R. 1992. Isotope ( $\mathrm{Pb}, \mathrm{Rb}-\mathrm{Sr}, \mathrm{S}, \mathrm{O}, \mathrm{C}, \mathrm{U}-\mathrm{Pb})$ geochemical investigations on Tertiary intrusives and related mineralizations in the Serbomacedonian $\mathrm{Pb}-\mathrm{Zn}, \mathrm{Sb}+\mathrm{Cu}-\mathrm{Mo}$ metallogenetic province in Northern Greece. Unpublished Doctoral dissertation, ETH Zurich. 
Fytikas, M., Vougioukalakis, G. 1992. Volcanic Structure and evolution of Kimolos and Polyaigos Isl.,(Milos Island Complex). In 6th Congress of the Greek Geologic Society (pp. 221-237).

Gale, N. H. 1979. Lead isotopes and Archaic Greek silver coins. Archaeophysica 10. Rheinisches Landesmuseum Bonn, pp 194-208.

525 Gale, N. H. 1998. The role of Kea in metal production and trade in the Late Bronze Age. KeaKythnos: History and Archaeology, 737-58.

Gale, N. H, Stos-Gale, Z. A. 1981a. Lead and silver in the ancient Aegean. Scientific American 244(6):176-192.

Gale, N. H, Stos-Gale, Z. A. 1981b. Cycladic lead and silver metallurgy. Annual of the British School at Athens 76:169-224.

Gale, N. H., Gentner, W., Wagner, G. A. 1980. Mineralogical and geographical silver sources of archaic Greek coinage. Metallurgy in numismatics, 1, 3-49.

Gialoglou, G., Drymniotis, D. 1983. Northeastern Greece: mining activities, mineral exploration and future developments. Trans. Inst. Min. Metall., Sect. A 92, A180-183.

Gentelli, L. Blichert-Toft, J., Davis, G., Gitler, H., and Albarède, F. (submitted) Metal provenance of Iron Age Hacksilber hoards in the southern Levant. Journal of Archaelogical Sciences.

Gentner, W., Müller, O., Wagner, G. A., Gale, N. H., 1978. Silver sources of archaic Greek coinage. Naturwissenschaften, 65(6), 273-284.

540 Grögler N, Geiss J, Grünenfelder, M, Houtermans, FG. 1966. Isotopenuntersuchungen zur Bestimmung der Herkunft römischer Bleirohre und Bleibarren.

ZeitschriftfürNaturforschung 21a:1167-72.

Grossou-Valta, M., Adam, K., Constantinides, D.C., Prevosteau, J.M., Dimou, E. 1990. Mineralogy of and potential beneficiation process for the Molai complex sulphide orebody, Greece. In Sulphide deposits - their origin and processing (pp. 119-133). Springer, Dordrecht.

Heyl, A.V., Landis, G.P., Zartman, R.E. 1974. Isotopic evidence for the origin of Mississippi valley-type mineral deposits: a review. Economic Geology 69, 992-1006.

Hudson, S.M., Johnson, C.L., Efendiyeva, M.A., Rowe, H.D., Feyzullayev, A.A., Aliyev, C.S. 2008. Stratigraphy and geochemical characterization of the Oligocene-Miocene Maikop series: implications for the paleogeography of Eastern Azerbaijan.

Tectonophysics 451, 40-55.

Institute of Geological and Mineral Exploration (IGME) 1965 Metallogenetic Map of Greece. Athens.

Jolivet, L., Brun, J. P., 2010. Cenozoic geodynamic evolution of the Aegean. International Journal of Earth Sciences, 99(1), 109-138.

Jolivet, L., Faccenna, C., Huet, B., Labrousse, L., Le Pourhiet, L., Lacombe, O., Lecomte, E., Burov, E., Denèle, Y., Brun, J.-P., Philippon, M., Paul, A., Salaün, G., Karabulut, H., 
Piromallo, C., Monié, P., Gueydan, F., Okay, A.I., Oberhänsli, R., Pourteau, A., Augier, R., Gadenne, L., Driussi, O., 2013. Aegean tectonics: strain localization, slab tearing and trench retreat. Tectonophysics 597, 1-33.

Kafousia, N., Karakitsios, V., Jenkyns, H., Mattioli, E. 2011. A global event with a regional character: the Early Toarcian Oceanic Anoxic Event in the Pindos Ocean (northern Peloponnese, Greece). Geological Magazine 148, 619-631.

565 Kalogeropoulos, S.I., Kilias, S.P., Bitzios, D.C., Nicolaou, M., Both, R.A. 1989. Genesis of the Olympias carbonate-hosted $\mathrm{Pb}-\mathrm{Zn}(\mathrm{Au}, \mathrm{Ag})$ sulfide ore deposit, easternChalkidiki Peninsula, northern Greece. Econ. Geol. 84, 1210-1234.

Kanellopoulos, C., Voudouris, P., Moritz, R. 2014. Detachment-related Sb-Pb-Zn-Ag-Au-Te mineralization in Kallintiri area, northeastern Greece: mineralogical and geochemical constraints. In Proc. 20th CBGA Congress, Tirana (pp. 162-165).

Keller, D. R. 1984. Archampolis, an early iron-age settlement and sanctuary in Southern Euboea. In American Journal of Archaeology (vol. 88, no. 2, pp. 249-249). 135 William St, New York, NY 10038-3805: Archaeological inst.

Killick, D., Stephens, J., Fenn, T., 2020. Geological constraints on the use of lead isotopes for provenance in archaeometallurgy, Archaeometry 62, 86-105.

Kontis, E., Kelepertsis, A. E., Skounakis, S. 1994. Geochemistry and alteration facies associated with epithermal precious metal mineralization in an active geothermal system, northern Lesbos, Greece. Mineralium Deposita, 29(5), 430-433.

Koukouli-Chrysanthaki, C. 1990. The mines of the Thasians' coast, Mélanges D. Lazaridis: cité et territoireenMacédoine et Thrace antiques, Recherches Franco-Helléniques, 1, Greek Ministry of Culture, École francaise d'Athénes, Athens (in Greek).

Leach, D.L., Sangster, D.F., Kelley, K.D., Large, R.R., Garven, G., Allen, C.R., Gutzmer, J., Walters, S. 2005. Sediment-hosted lead-zinc deposits: A global perspective, in: Hedenquist, J.W., Thompson, J.F.H., Goldfarb, R.J., Richards, J.P. (Eds.), Economic Geology 100th Annversary Volume. Society of Economic Geologists, Littleton, pp. 561-607.

Maratos, G. 1956. Brief report on the Taygetos mineralogical research. IGEY. Unpublished internal report. Athens. (in Greek).

Marinos, G., Petrascheck, W.E. 1956. Lavrion: geological and geophysical research. Institute for Geology and Subsurface Research 4, 1-246.

Melfos, V., Voudouris, P. 2016. Fluid evolution in Tertiary magmatic-hydrothermal ore systems at the Rhodope metallogenic province, NE Greece. A review. Geologia Croatica, 69(1), 157-167.

Melfos, V., Voudouris, P. 2017. Cenozoic metallogeny of Greece and potential for precious, critical and rare metals exploration. Ore Geology Reviews, 89, 1030-1057.

Melidonis, N., Constantinides, D. 1983. The stratabound sulphide Mineralisation of Syros (Cyclades, Greece). Z. dt. geol. Ges. 134, 555-575. 
Menant, A., Jolivet, L., Vrielynck, B. 2016. Kinematic reconstructions and magmatic evolution illuminating crustal and mantle dynamics of the eastern Mediterranean region since the late Cretaceous. Tectonophysics, 675, 103-140.

Milot, J., Blichert-Toft, J., Ayarzagüena Sanz, M., Fetter, N., Télouk, P., Albarède, F. (in press). The significance of galena $\mathrm{Pb}$ model ages and the formation of large $\mathrm{Pb}-\mathrm{Zn}$ sedimentary deposits. Chemical Geology.

Nebel, M.L., Hutchinson, R.W., Zartman, R.E. 1991. Metamorphism and polygenesis of the Madem Lakkos polymetallic sulfide deposit, Chalkidiki, Greece. Economic Geology, 86(1), pp.81-105.

Nesbitt, R. W., Billett, M. F., Ashworth, K. L., Deniel, C., Constantinides, D., Demetriades, A., Katirtzoglou, C., Michael, C., Mposkos, E., Zachos, S., Sanderson, D. 1988. The geological setting of base metal mineralisation in the Rhodope Region, northern Greece. In Mineral deposits within the European Community (pp. 499-514). Springer, Berlin, Heidelberg.

Pawlewicz, M. 2007. Total petroleum systems of the Carpathian-Balkanian basin province of Romania and Bulgaria. US Geological Survey.

Pe-Piper, G., Piper, D.J.W, 2002. The igneous rocks of Greece. The anatomyof an orogen, Beiträge der regionalen Geologie der Erde 30. Berlin-Stuttgart. 573 p.

Perlikos, P. 1989. Some new aspects on the geology and metallogeny of southern Euboea. Bull Geol Soc Greece 23:327-344 (in Greek).

Pernicka, E., Eibner, C., Öztunalı, O., Wagner, G. A. 2003. Early Bronze Age metallurgy in the north-east Aegean. In Troia and the Troad (pp. 143-172). Springer, Berlin, 620 Heidelberg.

Ross, J. R., Voudouris, P., Melfos, V., Vaxevanopoulos, M. 2020. Mines, Metals and Money in Attica and the Ancient World: The Geological Context. In: Sheedy, K. A., Davis, G. 2020. Metallurgy in Numismatics 6: Mines, Metals and Money: Ancient World Studies in Science, Archaeology and History.

625 Sachsenhofer, R., Popov, S., Coric, S., Mayer, J., Misch, D., Morton, M., Pupp, M., Rauball, J., Tari, G. 2018 Paratethyan petroleum source rocks: an overview. Journal of Petroleum Geology 41, 219-245.

Salemink, J. 1985. Skarn and ore formation at Seriphos, Greece as a consequence ofgranodiorite intrusion. GeologicaUntrajectina 40, $231 \mathrm{p}$.

Schmid, S. M., Fügenschuh, B., Kounov, A., Maţenco, L., Nievergelt, P., Oberhänsli, R., Pleuger, J., Schefer, S., Schuster, R. Tomljenovic, B., Ustaszewski, K., van Hinsbergen, D. J. 2020. Tectonic units of the Alpine collision zone between Eastern Alps and western Turkey. Gondwana Research, 78, 308-374.

Schmid, S.M., Bernoulli, D., Fügenschuh, B., Matenco, L., Schefer, S., Schuster, R., Tischler, M., Ustaszewski, K. 2008. The Alpine-Carpathian-Dinaridic orogenic system: correlation and evolution of tectonic units. Swiss J. Geosci. 101, 139-183. 
Shnyukov, E., Yanko-Hombach, V. 2020. Mud Volcanoes of the Black Sea Region and Their Environmental Significance. Springer Nature.

Siron, C.R. 2018. Magmatic, structural, and metallogenic framework of the Kassandra mining district, Chalkidiki peninsula, Northern Greece. Unpublished PhD Thesis.

Skarpelis, N. S. 1999. Epithermal type ores in the Aegean. The hot spring mineralization of northern Chios island, Greece. BGSG, 33, 61-68.

Skarpelis, N. 2020. Setting, sulfur isotope variations, and metamorphism of Jurassic massive $\mathrm{Zn}-\mathrm{Pb}-\mathrm{Ag}$ sulfide mineralization associated with arc- type volcanism (Skra, Vardar zone, Northern Greece). Resource Geology, 70(4), 311-335.

Stacey, J. S. \& Kramer, J. D. 1975. Approximation of terrestrial lead isotope evolution by a two-stage model. Earth Planet. Sci. Lett. 26, 207-221.

Stergiou, C., Melfos, V., Voudouris, P., Michailidis, K., Spry, P., Chatzipetros A. 2016. Hydrothermal alteration and structural control of the Vathi porphyry $\mathrm{Cu}-\mathrm{Au}-\mathrm{Mo}-\mathrm{U}$ ore system, Kilkis district, N. Greece. Scientific Annals of the School of Geology, Aristotle University of Thessaloniki (Honorary Publication in Memory of Professor A. KasoliFournaraki) 105, 69-74.

Stos-Gale, Z.A. 1998. The role of Kythnos and other Cycladic islands in the origins of Early Minoan metallurgy. Meletimata, 27, pp.717-736.

655 Stos-Gale, Z. A., Davis, G. 2020. The minting/mining nexus: new understandings of Archaic Greek silver coinage from lead isotope analysis. In Sheedy, K.A., Davis, G. (eds) Metallurgy in Numismatics 6: Mines, Metals and Money: Ancient World Studies in Science, Archaeology and History, Royal Numismatic Society Special Publications vol. 56, London, 87-100.

Stos-Gale, Z. A., Gale, N. H. 2009. Metal provenancing using isotopes and the Oxford archaeological lead isotope database (OXALID). Archaeological and Anthropological Sciences, 1(3), 195-213.

Stos- Gale, Z. A., Gale, N. H., Annetts, N. 1996. Lead isotope data from the Isotrace Laboratory, Oxford: archaeometry data base 3, ores from the Aegean, part 1. Archaeometry, 38(2), 381-390.

Stouraiti, C., Soukis, K., Voudouris, P., Mavrogonatos, C., Lozios, S., Lekkas, S., Beard, A., Strauss, H., Palles, D., Baziotis, I. Soulamidis, G. 2019. Silver-rich sulfide mineralization in the northwestern termination of the Western Cycladic Detachment System, at Agios Ioannis Kynigos, Hymettus Mt. (Attica, Greece): A mineralogical, geochemical and stable isotope study. Ore Geology Reviews, 111, 102992.

Tataris, A. 1960. Ai flevikai ekrixigeneis emfaniseis kai imetallogenesieis to Anat. Pilion. [In Greek] I.G.E.Y. Athens, VI, 4, 207-303.

Tombros, S., St. Seymour, K., Spry, P.G., Williams-Jones, A. 2007. The genesis of epithermal Au-Ag-Te mineralization, Panormos Bay, Tinos Island, Cyclades, Greece. Econ. Geol. 102, 1269-1294. 
Tsikos, H., Karakitsios, V., van Breugel, Y., Walsworth-Bell, B., Bombardiere, L., Petrizzo, M.R., Damsté, J.S.S., Schouten, S., Erba, E. Silva, I.P. 2004. Organic-carbon deposition in the Cretaceous of the Ionian Basin, NW Greece: the Paquier Event (OAE 1b) revisited. Geological Magazine 141, 401-416.

680 Vavelidis, M. 1988. Geochemistry of trace elements in galenas from Ag-containing lead-zinc ore deposits in Sifnos (Greece). Bull. Geol. Soc., 329-341.

Vavelidis, M., Amstutz, G.C. 1983. New genetic investigations on the Pb-Zn deposits of Thasos (Greece). In Mineral Deposits of the Alps and of the Alpine Epoch in Europe (pp. 359-365). Springer, Berlin, Heidelberg.

Vavelidis, M., Gialoglou, G., Melfos, V., Wagner, G.A. 1996. 'Goldgrube in Palaea Kavala Griechenland: Entdeckung von Skaptehyle', Erzmetall 49, 547-54.

Vaxevanopoulos, M. 2017. Recording and study of ancient mining activity on Mount Pangaeon, E. Macedonia, Greece. Unpublished Doctoral dissertation, Thessaloniki, Greece, Aristotle University of Thessaloniki. 337 (in Greek).

Vaxevanopoulos, M., Vavelidis, M., Melfos, V., Malamidou, D., Pavlides, S. 2018. Ancient Mining in Gold-Silver-Copper Deposits and Metallurgical Activity in Mavrokofi Area, Pangaeon Mount (NE Greece). In: Ben-Yosef, E. (ed.), Mining for Ancient Copper: Essays in Memory of Beno Rothenberg. Tel Aviv: The Institute of Archaeology of Tel Aviv University.

Veranis, N., Tsamantouridis, P., 1991. Using panning method to the exploration of auriferous mineralizations of Krousia metallogenic province. Institute of Geology and Mineral Exploration Internal Report (in Greek).

Voudouris, P. 2006. Comparative mineralogical study of Tertiary Te-rich epithermal and porphyry systems in northeastern Greece. Mineral. Petrol. 87, 241-275.

Voudouris, P., Alfieris, D. 2005. New porphyry- $\mathrm{Cu} \pm$ Mo occurrences in the north-eastern Aegean, Greece: Ore mineralogy and epithermal relationships. In Mineral deposit research: Meeting the global challenge (pp. 473-476). Springer, Berlin, Heidelberg.

Voudouris, P., Manoukian, E., Veligrakis, Th., Sakellaris, G.A., Koutsovitis, P., Falalakis, G., 2014. Carbonate-replacement and vein-type $\mathrm{Pb}-\mathrm{Zn}-\mathrm{Ag}$ - $\mathrm{Au}$ mineralization at Syros Island, Cyclades: Mineralogical and geochemical constraints. In: Proceedings 20th CBGA Congress, Tirana, Albania, Buletinii Shkencave Gjeologjike Special Issue 1, $183-186$.

Voudouris, P., Mavrogonatos, C., Spry, P. G., Baker, T., Melfos, V., Klemd, R., Haase, K., Repstock, A., Djiba, A., Bismayer, U., Tarantola, A., Scheffer, C., Moritz, R., Kouzmanov, K., Alfieris, D., Papavassiliou, K., Schaarschmidt, A., Galanopoulos, E., Galanos, E., Kolodziejczyk, J., Stergiou, C., Melfou, M. 2019. Porphyry and epithermal deposits in Greece: An overview, new discoveries, and mineralogical constraints on their genesis. Ore Geology Reviews, 107, 654-691.

Voudouris, P., Melfos, V., Mavrogonatos, C., Photiades, A., Moraiti, E., Rieck, B., Kolitsch, U., Tarantola, A., Scheffer, C., Morin, D.,Vanderhaeghe, O., Spry, P., Ross, J., Soukis, K., Vaxevanopoulos, M., Pekov, I., Chykanov, N., Magganas, A., Kati, M., 
Katerinopoulos, A., Zaimis, S. 2021. The Lavrion Mines: A Unique Site of Geological and Mineralogical Heritage. Minerals, 11(1), p.76.

Voudouris, P., Melfos, V., Spry, P.G., Bonsall, T., Tarkian, M., Economou-Eliopoulos, M., 2008a. Mineralogical and fluid inclusion constraints on the evolution of the Plaka intrusion-related ore system, Lavrion, Greece. Mineralogy and Petrology, 93(1-2), pp.79-110.

Voudouris, P., Melfos, V., Spry, P.G., Bonsall, T.A., Tarkian, M. and Solomos, C., 2008b. Carbonate-replacement $\mathrm{Pb}-\mathrm{Zn}-\mathrm{Ag} \pm$ Aumineralization in the Kamariza area, Lavrion, Greece: Mineralogy and thermochemical conditions of formation. Mineralogy and Petrology, 94(1-2), p.85.

Voudouris, P., Spry, P.G., Sakellaris, G.A., Mavrogonatos, C. 2011. A cervelleite-like mineral and other Ag-Cu-Te-S minerals $[\mathrm{Ag} 2 \mathrm{CuTeS}$ and $(\mathrm{Ag}, \mathrm{Cu}) 2 \mathrm{TeS}]$ in gold bearing veins in metamorphic rocks of the Cycladic Blueschist Unit, Kallianou, Evia Island, Greece. Mineral. Petrol. 101, 169-183.

Voudouris P, Skarpelis N. 1998. Epithermal gold-silver mineralization at Perama (Thrace) and Lemnos Island. Geol Soc Greece Bull 32:125-135.

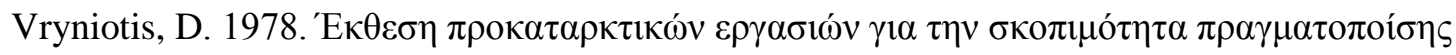

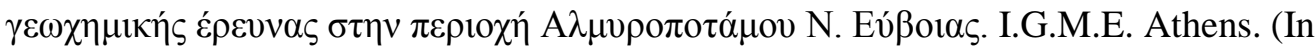
Greek).

Wagner, G. A, Gentner, W., Gropengiesser H., Gale, N. H. 1980. Early bronze age lead-silver mining and metallurgy in the Aegean. In: Craddock PT (ed) Scientific studies in early mining and extractive metallurgy. British Museum Occasional Paper 20:63-86.

Wagner, G. A, Weisgerber, G., 1985. Silber, Blei und Gold auf Sifnos, prähistorische und antike Metallproduktion, Der Anschnitt, Beiheft 3. Deutsches Bergbau-Museum, Bochum.

Wagner, G. A., Weisgerber, G., (eds). 1988. "Antike Edel- und Buntmetallgewinnung auf Thasos." Der Anschnitt: Beiheft 6 (Veröffentlichung aus dem Deutschen BergbauMuseum Nr. 42). Bochum 1988.

Wagner, G.A., Pernicka, E., Vavelidis, M., Baranyi, I., Bassiakos, I. 1986. Archaeometallurgische Untersuchungen auf Chalkidiki. Anschnitt, 38, H5-6, 166-186.

Wilkinson, J. 2013. Sediment-Hosted Zinc-Lead Mineralization: Processes and Perspectives: Processes and Perspectives, Treatise on Geochemistry. Elsevier Ltd.

Wind, S. C., Schneider, D. A., Hannington, M. D., McFarlane, C. R. 2020. Regional similarities in lead isotopes and trace elements in galena of the Cyclades Mineral District, Greece with implications for the underlying basement. Lithos, 366, 105559.

Xydopoulos, I. 2016. The Eastern Macedonian border in Alexander I's reign. In: HXA $\Delta \mathrm{IN}$.

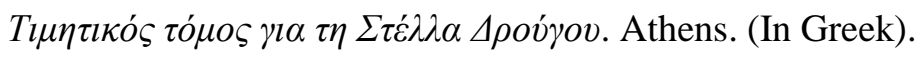


Figure 1. Geographic map depicting the Ag-bearing mineralizations of Greece (base map modified after SRTM worldwide elevation data 3-arc-second resolution).

Figure 2. Simplified geotectonic map of the Aegean region showing the main tectonic zones within the Hellenide orogen (modified after Schmid et al., 2008; 2020). Silver-bearing mineralizations are shown (Tables 1 and 3 and references therein). The North Cycladic Detachment System (NCDS) and the West Cycladic Detachment System (WCDS) are also depicted.

Figure 3. Selected representative photos from the mining areas where samples were obtained. (a) Esperanza-1 horizontal mine in Lavrion. (b) Dimoliaki mine supergene alteration close to the Plaka granodiorite intrusion. (c) Gialpides-1 mine in the Euboea mining district. (d) Ancient adits in the modern trench of Agios Silvestros mining area in Siphnos. (e) Agios Sostis-1 ancient mine in Siphnos. (f) Modern mine intersected by ancient gallery in Moutoula mining area in Seriphos. $(g)$ Ancient mine entrance at the shore of Kastellas area in Kythnos island. (h) Ksourichti mine in Pelion mining area. (i) Horizontal mine OLY-12 in Olympiada Chalkidiki mining district. (j) Acropolis mine in the northeast part of Thasos island. ( $k$ ) Koulachli-1 ancient mine in Kroussia mountain. (l) Koryfis-1 mine in Pangaeon mountain. (m) Lazaros ancient mine in Palaea Kavala.

Figure 4. Measured Pb isotopic compositions of galena, cerussite, and anglesite from ancient Greek mining territories and selected Ag-bearing occurrences in Greece. (a) ${ }^{207} \mathrm{~Pb} /{ }^{204} \mathrm{~Pb}$ versus ${ }^{206} \mathrm{~Pb} /{ }^{204} \mathrm{~Pb},(b){ }^{208} \mathrm{~Pb} /{ }^{204} \mathrm{~Pb}$ versus ${ }^{206} \mathrm{~Pb} /{ }^{204} \mathrm{~Pb},(c){ }^{208} \mathrm{~Pb} /{ }^{206} \mathrm{~Pb}$ versus ${ }^{207} \mathrm{~Pb} /{ }^{206} \mathrm{~Pb},(d)$ $T_{\text {mod }}\left(\mathrm{Pb}\right.$ model age) versus $\mu\left({ }^{238} \mathrm{U}{ }^{204} \mathrm{~Pb}\right)$, (e) $T_{\text {mod }}\left(\mathrm{Pb}\right.$ model age) versus $\kappa\left({ }^{232} \mathrm{Th}{ }^{238} \mathrm{U}\right)$. Literature data (Barnes et al., 1975; Gale and Stos-Gale, 1981a; Wagner and Weisgerber, 1985; Wagner et al., 1986; Kalogeropoulos et al., 1989; Nebel et al., 1991; Frei, 1992; StosGale et al., 1996; Gale, 1998; Asderaki et al., 2017; OXALID and IGME unpublished data) provided in Table 3 is depicted with crosses. Lead model ages calculated according to Albarède and Juteau (1984).

Figure 5. Maps of $(a){ }^{206} \mathrm{~Pb}{ }^{204} \mathrm{~Pb},(b){ }^{207} \mathrm{~Pb} /{ }^{204} \mathrm{~Pb},(c){ }^{208} \mathrm{~Pb}{ }^{204} \mathrm{~Pb},(d){ }^{207} \mathrm{~Pb}{ }^{206} \mathrm{~Pb}$, and $(e)$ ${ }^{208} \mathrm{~Pb}{ }^{206} \mathrm{~Pb}$. Data from this study only.

Figure 6. Maps of (a) $T_{\text {mod }}\left(\mathrm{Pb}\right.$ model age ), (b) $\mu\left({ }^{238} U{ }^{204} \mathrm{~Pb}\right)$, and (c) $\kappa\left({ }^{232} \mathrm{Th} \mathrm{f}^{238} \mathrm{U}\right)$. Data from this study and literature data (Tables 2 and 3).

Figure 7. One-dimensional histogram of $\mathrm{Pb}$ model ages from Greek Ag-bearing mineralizations (data from this study and literature data; Tables 2 and 3). Lead model ages were calculated with the assumption of a mixture of five normal populations.

\section{TABLE CAPTIONS}

Table 1. Characteristics of Ag-bearing mineralizations in Greece.

Table 2. High-precision Pb isotopic compositions of Ag-bearing localities in Greece.

Table 3. Lead isotope data from the literature (Barnes et al., 1975; Gale and Stos-Gale, 1981a; Wagner and Weisgerber, 1985; Wagner et al., 1986; Kalogeropoulos et al., 1989;

795 Nebel et al., 1991; Frei, 1992; Stos-Gale et al., 1996; Gale, 1998; Asderaki et al., 2017; OXALID and IGME unpublished data). 
Table 4. Characteristics of the recorded mining and metallurgical activity based on field observations. Extended mining areas are separated in subdistricts.

Table 5. Mean and standard-deviation of $T_{m o d}, \mu$, and $\kappa$ inferred from a 5-group mixing model found in the galena samples analyzed in this work. $N$ stands for the number of samples in each group and sfor standard deviation. Note the differences between the results when literature data are included, which reflects the smaller number and much broader peaks observed in the histogram of Fig. 7. The present groups are compared with the groups identified by Milot et al. (in press) for the Iberian Peninsula. Groups 1 (N=42), 2 (79), and 3 $805(N=22)$ are the most populated. Note that the very strong Cenozoic peak $(35 \pm 9 \mathrm{Ma})$ is absent from Iberia, where late Devonian (395 $\pm 40 \mathrm{Ma}$ ) prevails. The Cretaceous peaks are strong in

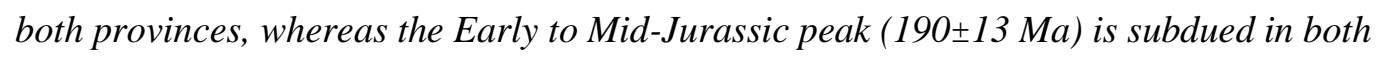
provinces. 


\begin{tabular}{|c|c|c|c|c|c|c|c|}
\hline & Ore District & Geotectonic Unit & $\begin{array}{l}\text { Other Major Met. } \\
\text { Compounds }\end{array}$ & Host Geology & Deposit Type/Style & Mineralization Age & Indicative References \\
\hline 1 & Lavrion & Attic-Cycladic Massif & $\mathrm{Pb}, \mathrm{Zn}, \mathrm{Fe}, \mathrm{Cu}, \mathrm{As}, \mathrm{Sn}, \mathrm{Au}$ & Marble, schist, granodiorite & $\begin{array}{l}\text { Carbonate } \\
\text { replacement, veins, } \\
\text { intrusion related }\end{array}$ & Upper Miocene & $\begin{array}{l}\text { Marinos and Petracheck, 1956; } \\
\text { Conophagos, 1980; Voudouris et al, } \\
\text { 2008a; b; Bonsall et al, 2011; Voudouris } \\
\text { et al, } 2021\end{array}$ \\
\hline 2 & South Euboea & Attic-Cycladic Massif & $\mathrm{Pb}, \mathrm{Zn}, \mathrm{Cu}, \mathrm{Fe}, \mathrm{As}, \mathrm{Au}$ & Schist, gneiss, marble & Detachment fault & Miocene & Perlikos, 1989; Voudouris et al, 2011 \\
\hline 3 & $\begin{array}{c}\text { Central Euboea } \\
\text { (Almyropotamos) }\end{array}$ & Attic-Cycladic Massif & $\mathrm{Fe}, \mathrm{Pb}, \mathrm{Zn}, \mathrm{As}$ & Marble, schist & Fault controled, veins & & Vryniotis, 1978; this study \\
\hline 4 & Siphnos & Attic-Cycladic Massif & $\mathrm{Fe}, \mathrm{Mn}, \mathrm{Cu}, \mathrm{Pb}, \mathrm{Zn}, \mathrm{Au}$ & Marble, gneiss, schist & $\begin{array}{c}\text { Detachment fault/ } \\
\text { Carbonate replacement }\end{array}$ & Miocene & $\begin{array}{l}\text { Wagner and Weisgerber, 1985; Vavelidis, } \\
\text { 1988; this study }\end{array}$ \\
\hline 5 & Seriphos & Attic-Cycladic Massif & $\mathrm{Fe}, \mathrm{Pb}, \mathrm{Zn}, \mathrm{As}, \mathrm{Cu}$ & Schist, marble & $\mid \begin{array}{c}\text { Detachment fault/ } \\
\text { Carbonate replacement }\end{array}$ & Upper Miocene & $\begin{array}{l}\text { Gale and Stos-Gale, 1981b; Ducoux et al, } \\
2017\end{array}$ \\
\hline 6 & Melos & Attic-Cycladic Massif & $\mathrm{Pb}, \mathrm{Zn}, \mathrm{Cu}, \mathrm{Au}$ & $\begin{array}{c}\text { Rhyolite, dacite, andesites, pyroclastic } \\
\text { rocks }\end{array}$ & Epithermal & $\begin{array}{l}\text { Pliocene to } \\
\text { Pleistocene }\end{array}$ & Alfieris et al, 2013 \\
\hline 7 & Syros & Attic-Cycladic Massif & $\mathrm{Fe}, \mathrm{Pb}, \mathrm{Zn}, \mathrm{Cu}, \mathrm{Sn}, \mathrm{Au}$ & Marble, schist & $\begin{array}{l}\text { Detachment fault/ } \\
\text { Carbonate } \\
\text { replacement, veins }\end{array}$ & Upper Miocene & $\begin{array}{l}\text { Melidonis and Konstantinidis, 1983; } \\
\text { Voudouris et al, } 2014\end{array}$ \\
\hline 8 & Kythnos & Attic-Cycladic Massif & $\mathrm{Fe}, \mathrm{Pb}, \mathrm{Zn}, \mathrm{Cu}, \mathrm{Au}$ & Marble, schist & $\begin{array}{c}\text { Detachment } \\
\text { fault/Carbonate } \\
\text { replacement }\end{array}$ & & $\begin{array}{l}\text { Stos-Gale, 1998; Bassiakos and } \\
\text { Philaniotou, 2007; this study }\end{array}$ \\
\hline 9 & Antiparos & Attic-Cycladic Massif & $\mathrm{Pb}, \mathrm{Zn}, \mathrm{Fe}, \mathrm{Cu}$ & Marble, schist & Epithermal & Miocene & $\begin{array}{l}\text { Gale and Stos-Gale, 1981b; Voudouris et } \\
\text { al, } 2019\end{array}$ \\
\hline 10 & Polyaigos & Attic-Cycladic Massif & $\mathrm{Pb}, \mathrm{Zn}$ & Ignimbrite, andesite & Epithermal & & $\begin{array}{l}\text { Fytikas and Vougioukalakis, 1992; this } \\
\text { study }\end{array}$ \\
\hline 11 & Thera & Attic-Cycladic Massif & $\mathrm{Pb}, \mathrm{Fe}, \mathrm{Cu}, \mathrm{Zn}$ & Phyllitic schist & Epithermal & & Gale, 1998 \\
\hline 12 & Anaphi & Attic-Cycladic Massif & $\mathrm{Pb}, \mathrm{Zn}$ & Marble, granodiorite & Epithermal & & Voudouris et al, 2019; this study \\
\hline 13 & Kos & Pelagonic zone & $\mathrm{Pb}, \mathrm{Zn}$ & Marble breccia & Veins & & IGME, 1965 \\
\hline 14 & Samos & Attic-Cycladic Massif & $\mathrm{Pb}, \mathrm{Fe}, \mathrm{Au}$ & $\begin{array}{l}\text { Pyroclastics, conglomerates and } \\
\text { carbonates }\end{array}$ & Epithermal & Miocene & IGME, 1965; Voudouris et al, 2019 \\
\hline 15 & Mykonos & Attic-Cycladic Massif & $\mathrm{Fe}, \mathrm{Pb}, \mathrm{Zn}, \mathrm{Cu}, \mathrm{Au}$ & Monzogranite, schist & Veins & Miocene & IGME, 1965; Voudouris et al, 2019 \\
\hline 16 & Tinos & Attic-Cycladic Massif & $\mathrm{Pb}, \mathrm{Zn}, \mathrm{Au}$ & Marble, schist & Epithermal & Miocene & $\begin{array}{l}\text { Tombros et al, 2007; Voudouris et al, } \\
2019\end{array}$ \\
\hline 17 & Kea & Attic-Cycladic Massif & $\mathrm{Pb}, \mathrm{Fe}$ & Marble & Veins & & Gale, 1998 \\
\hline 18 & Tyros & Gavrovo Unit & $\mathrm{Pb}, \mathrm{Zn}$ & Marble & VMS & Triassic & IGME, 1965; Skarpelis, 2020 \\
\hline 19 & Molaoi & Gavrovo Unit & $\mathrm{Pb}, \mathrm{Zn}$ & Tuffs, tuffites lavas and pyroclastics & VMS & Triassic & Grossou-Valta et al, 1990 \\
\hline 20 & Taygetus & Ionian Zone & $\mathrm{Pb}, \mathrm{Zn}, \mathrm{Fe}, \mathrm{Cu}, \mathrm{Au}$ & Schist & Veins/VMS? & & Maratos, 1956 \\
\hline 21 & Hymettus & Attic-Cycladic Massif & $\mathrm{Fe}, \mathrm{Pb}, \mathrm{As}, \mathrm{Cu}$ & Schist, marble & $\begin{array}{c}\text { Carbonate } \\
\text { Replacement }\end{array}$ & Upper Miocene & |IGME; 1965; Stouraiti et al, 2019 \\
\hline 22 & Chios & Sakarya Block & $\mathrm{Pb}, \mathrm{Zn}, \mathrm{Au}$ & Clastic sediments & Epithermal & Mid-Miocene & Skarpelis, 1999 \\
\hline 23 & Pelion & Pelagonic zone & $\mathrm{Fe}, \mathrm{Pb}, \mathrm{Zn}, \mathrm{Cu}$ & Schist, Marble & $\begin{array}{l}\text { Veins / Carbonate } \\
\text { replacement }\end{array}$ & & Tataris, 1960; this study \\
\hline 24 & Lesbos (Argenos) & Rhodope Massif-Sakarya & $\mathrm{Fe}, \mathrm{Pb}, \mathrm{Zn}, \mathrm{Cu}, \mathrm{Au}$ & Dacite, trachyandesite & Epithermal & Upper Miocene & $\begin{array}{l}\text { Kontis et al, 1994; Pernicka et al, 2003; } \\
\text { Voudouris et al, } 2019\end{array}$ \\
\hline 25 & Limnos (Fakos) & Rhodope Massif & $\mathrm{Pb}, \mathrm{Zn}, \mathrm{Cu}, \mathrm{As}, \mathrm{Au}$ & Sandstone, monzodiorite & Epithermal & Lower Miocene & $\begin{array}{l}\text { Voudouris and Skarpelis, 1998; Voudouris } \\
\text { and Alfieris, 2005; Voudouris et al, } 2019\end{array}$ \\
\hline
\end{tabular}




\begin{tabular}{|c|c|c|c|c|c|c|c|}
\hline 26 & Samothrace & Circum Rhodope Belt & $\mathrm{Pb}, \mathrm{Fe}, \mathrm{Cu}$ & Granite & Epithermal & Miocene & Voudouris et al, 2019 \\
\hline 27 & Sykia Chalkidiki & Circum Rhodope Belt & $\mathrm{Pb}, \mathrm{Cu}, \mathrm{Zn}, \mathrm{Fe}$ & Granodiorite & Veins & & IGME, 1965; Wagner et al, 1986 \\
\hline 28 & $\begin{array}{c}\text { NE Chalkidiki (Olympiada, } \\
\text { Madem Lakkos, Mavres } \\
\text { Petres) }\end{array}$ & Rhodope Massif & $\mathrm{Pb}, \mathrm{Zn}, \mathrm{Cu}, \mathrm{As}, \mathrm{Au}$ & Marble, gneiss, amphibolite & $\begin{array}{c}\text { Carbonate } \\
\text { replacement, intrusion } \\
\text { related }\end{array}$ & Oligocene & $\begin{array}{l}\text { Wagner et al, 1986; Kalogeropoulos et al, } \\
\text { 1989; Siron et al, } 2016\end{array}$ \\
\hline 29 & Thasos & Rhodope Massif & $\mathrm{Fe}, \mathrm{Mn}, \mathrm{Pb}, \mathrm{Zn}, \mathrm{Cu}, \mathrm{As}, \mathrm{Au}$ & Marble, gneiss, schist & $\begin{array}{c}\text { Carbonate } \\
\begin{array}{c}\text { replacement, intrusion } \\
\text { related }\end{array} \\
\end{array}$ & Miocene & $\begin{array}{l}\text { Vavelidis and Amstutz, 1983; Wagner and } \\
\text { Weisgerber, } 1988\end{array}$ \\
\hline 30 & $\begin{array}{l}\text { Kilkis (Drakontio, } \\
\text { Stefania, Koronouda) }\end{array}$ & Vertiskos Unit & $\mathrm{Pb}, \mathrm{Zn}, \mathrm{Cu} . \mathrm{Au}$ & Gneiss, schist, amphibolite & Intrusion related & Oligocene-Miocene & Melfos and Voudouris, 2017 \\
\hline 31 & Kroussia & Vertiskos Unit & $\mathrm{Pb}, \mathrm{Zn}, \mathrm{Cu} . \mathrm{Au}$ & Schist, gneiss, marble & $\begin{array}{c}\text { Carbonate replacement } \\
\text { / Porphyry }\end{array}$ & & $\begin{array}{l}\text { IGME, 1965; Veranis and Tsamantouridis, } \\
\text { 1991; Stergiou et al, } 2016\end{array}$ \\
\hline 32 & Skra & Circum Rhodope Belt & $\mathrm{Pb}, \mathrm{Zn}$ & $\begin{array}{l}\text { Rhyodacitic lavas, pyroclastics, porphyries } \\
\text { and cherty tuffs }\end{array}$ & VMS & Upper Jurassic & Skarpelis, 2020 \\
\hline 33 & Angistron & Rhodope Massif & $\mathrm{Fe}, \mathrm{Mn}, \mathrm{Pb}, \mathrm{Zn}, \mathrm{Cu}, \mathrm{Au}$ & Marble & $\begin{array}{l}\text { Veins/ Carbonate } \\
\text { replacement }\end{array}$ & & Chiotis et al, 1996; this study \\
\hline \multirow{2}{*}{34} & \multirow{2}{*}{ Pangaeon } & Rhodope Massif & \multirow{2}{*}{$\mathrm{Pb}, \mathrm{Zn}, \mathrm{Cu}, \mathrm{Fe}, \mathrm{Mn}, \mathrm{Au}$} & \multirow{2}{*}{ Marble, schist, gneiss, amphibolite } & \multirow{2}{*}{$\begin{array}{c}\text { Intrusion related/ } \\
\text { Carbonate replacement }\end{array}$} & \multirow{2}{*}{ Miocene } & \multirow{2}{*}{ Vaxevanopoulos, 2017; 2018} \\
\hline & & Serbomacedonian Zone & & & & & \\
\hline 35 & Palaea Kavala & Rhodope Massif & $\mathrm{Fe}, \mathrm{Mn}, \mathrm{Pb}, \mathrm{Zn}, \mathrm{Cu}, \mathrm{Au}$ & Marble, gneiss, schist, granodiorite & $\begin{array}{c}\text { Intrusion related/ } \\
\text { Carbonate replacement }\end{array}$ & Miocene & Vavelidis et al, 1996; Fornadel et al, 2011 \\
\hline 36 & Thermes & Rhodope Massif & $\mathrm{Fe}, \mathrm{Pb}, \mathrm{Zn}, \mathrm{Cu}, \mathrm{Au}$ & Marble, gneiss, amphibolite & $\begin{array}{l}\text { Carbonate } \\
\text { replacemement }\end{array}$ & Oligocene & $\begin{array}{l}\text { Gialoglou and Drymniotis, 1983; } \\
\text { Kalogeropoulos et al, 1996; Nesbitt et al, } \\
1998\end{array}$ \\
\hline 37 & Perama Hill & Circum Rhodope Belt & $\mathrm{Cu}, \mathrm{Pb}, \mathrm{Au}$ & Andesite, breccia, sandstone & Epithermal & Oligocene & Voudouris and Skarpelis, 1998 \\
\hline 38 & Kallintiri & Circum Rhodope Belt & $\mathrm{Pb}, \mathrm{Zn}, \mathrm{Au}$ & Marble, schist & Pollymetalic & Oligocene & $\begin{array}{l}\text { Kanellopoulos, 2014; Melfos and } \\
\text { Voudouris, } 2017\end{array}$ \\
\hline 39 & Sappes & Circum Rhodope Belt & $\mathrm{Fe}, \mathrm{Cu}, \mathrm{Pb}, \mathrm{Zn}, \mathrm{Au}$ & Monzodiorite & Epithermal & Oligocene & Voudouris et al, 2006 \\
\hline 40 & Kirki & Circum Rhodope Belt & $\mathrm{Fe}, \mathrm{Cu}, \mathrm{Pb}, \mathrm{Zn}, \mathrm{As}, \mathrm{Sn}, \mathrm{Au}$ & Andesite & Epithermal & Oligocene & $\begin{array}{l}\text { Nesbitt et al, 1988; Melfos and } \\
\text { Voudouris, } 2017\end{array}$ \\
\hline 41 & Aisymi & Circum Rhodope Belt & $\mathrm{Fe}, \mathrm{Pb}, \mathrm{Zn}, \mathrm{Cu}$, & Granodiorite & Epithermal & Oligocene & Voudouris et al, 2006 \\
\hline 42 & Neda (King Arthour) & Rhodope Massif & $\mathrm{Fe}, \mathrm{Pb}, \mathrm{Cu}, \mathrm{Zn}$ & Andesite-Gneiss & Epithermal & Oligocene & Nesbitt et al, 1988; Voudouris et al, 2019 \\
\hline 43 & Pefka & Circum Rhodope Belt & $\mathrm{Pb}, \mathrm{Cu}, \mathrm{Zn}, \mathrm{As}, \mathrm{Bi}, \mathrm{Sn}, \mathrm{Au}$ & Rhyodacitic lavas and pyroclastics & Epithermal & Oligocene & $\begin{array}{l}\text { Voudouris, 2006; Melfos and Voudouris, } \\
2017\end{array}$ \\
\hline 44 & Loutros & Circum Rhodope Belt & $\mathrm{Fe}, \mathrm{Pb}, \mathrm{As}$ & Rhyolite & Epithermal & Miocene & Melfos and Voudouris, 2016; 2017 \\
\hline
\end{tabular}




\begin{tabular}{|c|c|c|c|c|c|c|c|c|}
\hline Sample & Region & District / Mine & Mining Phase & Mineralization & Host Rock & $\mathrm{Ag}$ (ppm) & $\mathrm{Pb}(w \mathrm{t} \%)$ & ${ }^{206} \mathrm{~Pb} /{ }^{204} \mathrm{~Pb}$ \\
\hline L-01 & Lavrion & Hilarion & Ancient & Gal, Conich, Goeth & Marble & 320.844 & 19.599 & 18.8401 \\
\hline $\mathrm{L}-02 \mathrm{~A}$ & Lavrion & Porto-09 & Modern-Ancient & Gal & Schist & 124.200 & 18.090 & 18.8591 \\
\hline L-02B & Lavrion & Porto-09 & Modern-Ancient & Gal & Schist & 107.184 & 12.862 & 18.8593 \\
\hline L-03 & Lavrion & Ari & Ancient & Gal & Marble & 294.591 & 15.730 & 18.8635 \\
\hline L-04 & Lavrion & Esperanza & Ancient & Cer, Angl & Marble & 182.346 & 1.142 & 18.8688 \\
\hline L-05 & Lavrion & Dimoliaki & Ancient & Goeth, Gal & Marble & 20.856 & 3.491 & 18.8744 \\
\hline L-06 & Lavrion & Jean Vaptiste & Modern-Ancient & Gal, Cer, Mal, Con & Marble & 1673.407 & 70.729 & 18.8599 \\
\hline L-07 & Lavrion & Esperanza & Modern-Ancient & Gal, Cer & Marble & 1977.548 & 67.949 & 18.8607 \\
\hline L-08 & Lavrion & Plaka-80 & Modern & Gal, Spha & Marble & 1656.376 & 51.957 & 18.8906 \\
\hline L-09 & Lavrion & Plaka-80 & Modern & Gal, Spha & Marble & 3029.485 & 65.682 & 18.8845 \\
\hline L-10 & Lavrion & Dimoliaki & Ancient & Cer, Gal, Goeth & Marble & 1181.700 & 32.512 & 18.8741 \\
\hline L-11 & Lavrion & Plaka-145 & Modern & Gal & Marble & 5872.432 & 65.728 & 18.8762 \\
\hline L-12 & Lavrion & Esperanza & Ancient & Gal, Spha & Marble & 1959.088 & 79.339 & 18.8649 \\
\hline L-13 & Lavrion & Esperanza & Ancient & Gal, Spha & Marble & 2005.232 & 69.751 & 18.8670 \\
\hline L-14 & Lavrion & Esperanza & Ancient & Spha, Gal & Marble & 329.663 & 0.972 & 18.8594 \\
\hline L-15 & Lavrion & Esperanza & Ancient & Spha, Gal & Marble & 332.786 & 0.982 & 18.8625 \\
\hline L-16 & Lavrion & HIL-24 & Ancient & Gal, Cer & Marble & 17.637 & 0.023 & 18.8220 \\
\hline L-17 & Lavrion & Poundazeza & Ancient & Gal & Marble & 4219.914 & 55.620 & 18.8764 \\
\hline L-26 & Lavrion & Sounio-06 & Modern-Ancient & Cer & Marble & 2.407 & 0.289 & 18.8238 \\
\hline L-32 & Lavrion & Elafos & Modern-Ancient & Goeth, Cer & Marble & 0.000 & 0.717 & 18.8515 \\
\hline L-34 & Lavrion & Dimoliaki & Ancient & Cer, Gal, Goeth, Smith & Marble & 2463.710 & 22.195 & 18.8637 \\
\hline L-40 & Lavrion & Sykia & Ancient & Gal, Cer & Marble & 1036.609 & 42.923 & 18.8602 \\
\hline L-41 & Lavrion & Mpotsari & Ancient & Gal, Cer & Marble & 3669.772 & 70.541 & 18.8504 \\
\hline L-42 & Lavrion & Christiana & Modern-Ancient & Gal, Cer & Marble & 3951.002 & 70.371 & 18.8642 \\
\hline L-43 & Lavrion & MAN-HOR-1 & Ancient & Cer, Goeth & Marble & 40.223 & 10.804 & 18.8792 \\
\hline L-47 & Lavrion & Thorikos Mine & Ancient & Goeth, Cer & Marble & 0.000 & 3.643 & 18.8727 \\
\hline $\mathrm{E}-01$ & Euboea & Kordelas & Modern & Gal & Marble & 19.897 & 2.243 & 18.6864 \\
\hline $\mathrm{E}-02$ & Euboea & St Barbara & Modern & Gal & Marble & 583.086 & 1.620 & 18.6935 \\
\hline $\mathrm{E}-03$ & Euboea & St Barbara & Modern & Gal & Marble & 86.947 & 0.879 & 18.7024 \\
\hline $\mathrm{E}-05$ & Euboea & Moskies & Ancient & Gal & Marble & 730.871 & 40.775 & 18.6893 \\
\hline E-06 & Euboea & Moskies & Ancient & Gal, Py, & Marble & 509.115 & 29.896 & 18.6869 \\
\hline GIA-02A & Euboea & Gialpides & Ancient & Cpy, Cer & Marble & 10.946 & 0.020 & 18.7279 \\
\hline GIA-02B & Euboea & Gialpides & Ancient & Cpy, Cer & Marble & 48.824 & 0.023 & 18.6715 \\
\hline SCHI-01A & Euboea & Schinodavli Mine & Ancient & Goeth, Cer & Schist & 0.000 & 0.041 & 18.6742 \\
\hline SCHI-01B & Euboea & Schinodavli Mine & Ancient & Goeth, Cer & Schist & 0.919 & 0.042 & 18.7249 \\
\hline AL-01 & Euboea & Almyropotamos Mine-01 & Modern-Ancient & Cer, Goeth & Marble & 91.447 & 6.968 & 18.7987 \\
\hline AL-02 & Euboea & Almyropotamos Mine-02 & Modern-Ancient & Cer, Goeth & Marble & 65.291 & 14.076 & 18.7802 \\
\hline AL-03 & Euboea & Almyropotamos Mine-07 & Modern-Ancient & Cer, Goeth & Marble & 74.679 & 10.301 & 18.7929 \\
\hline SI-02 & Siphnos & Ai Sostis & Ancient & Goeth, Cer, Hem, Pyrol & Marble & 13.244 & 6.438 & 18.7367 \\
\hline SI-03 & Siphnos & Ai Sostis & Ancient & Goeth, Hem, Pyrol, Cer & Marble & 1.710 & 2.660 & 18.7291 \\
\hline SI-10 & Siphnos & Agios Silvestros & Ancient & Goeth, Hem, Pyrol, Gal, Cer & Marble & 4983.329 & 7.107 & 18.7361 \\
\hline SI-11 & Siphnos & Xero Xylo & Ancient & Cer, Goet, Hem & Marble & 126.393 & 0.430 & 18.7298 \\
\hline $\mathrm{SI}-13$ & Siphnos & Kapsalos-Frase & Ancient-Modern & Cer, Goet, Hem & Marble & 20.985 & 2.287 & 18.7273 \\
\hline SI-14 & Siphnos & Ai Sostis & Ancient & Cer, Goet, Hem & Marble & 3.199 & 0.761 & 18.7344 \\
\hline SI-15 & Siphnos & Xero Xylo & Ancient-Modern & Cer, Goet, Hem & Marble & 40.233 & 0.478 & 18.7265 \\
\hline SE-02 & Seriphos & Moutoula-07 & Ancient & Gal & Marble & 161.506 & 69.965 & 18.9000 \\
\hline SE-03 & Seriphos & Moutoula-08 & Ancient & Gal & Marble & 470.289 & 85.248 & 18.9024 \\
\hline M-01A & Melos & Agios Nikolaos & Modern-Ancient & Gal & Tuff & 2388.673 & 66.390 & 18.8601 \\
\hline$M-01 B$ & Melos & Agios Nikolaos & Modern-Ancient & Gal & Tuff & 2473.074 & 28.166 & 18.8619 \\
\hline M-03A & Melos & Triades & Modern-Ancient & Goeth, Cer & Tuff & 1.475 & 0.014 & 18.8205 \\
\hline M-03B & Melos & Triades & Modern-Ancient & Goeth, Cer & Tuff & 6.018 & 0.003 & 18.8200 \\
\hline SYR-04 & Syros & Azolimnos & Modern & Gal, Cer & Marble & 0.971 & 0.171 & 18.8401 \\
\hline SYR-06 & Syros & Rozos & Ancient & Gal, Cer & Marble & 1.181 & 0.001 & 18.8178 \\
\hline SYR-07 & Syros & Rozos & Ancient & Gal, Cer & Marble & 26.091 & 0.821 & 18.8296 \\
\hline SYR-08 & Syros & Rozos & Ancient & Gal, Cer & Marble & 0.781 & 0.128 & 18.8208 \\
\hline SYR-09 & Syros & Rozos & Ancient & Gal, Cer & Marble & 23.202 & 0.418 & 18.8202 \\
\hline SYR10 & Syros & Rozos & Modern & Gal, Cer & Marble & 1.343 & 0.366 & 18.8376 \\
\hline KY-01 & Kythnos & Agios Dimitrios Mine & Ancient & Goeth, cer & Marble & 0.000 & 0.187 & 18.9374 \\
\hline KY-02 & Kythnos & Agios Dimitrios & Modern & Goeth, cer & Marble & 12.986 & 0.595 & 18.9225 \\
\hline KY-05 & Kythnos & Katafyki Mine & Modern & Goeth, cer & Marble & 0.772 & 0.003 & 18.8357 \\
\hline KY-08 & Kythnos & Kastellas & Ancient & Goeth, cer & Marble & 0.231 & 0.956 & 18.9053 \\
\hline KY-10 & Kythnos & Tourkala & Modern & Goeth, cer & Marble & 16.189 & 0.035 & 18.8271 \\
\hline AN-02 & Antiparos & Monastiria Mine 1 & Modern-Ancient & Cer, Gal & Gneiss & 339.640 & 55.828 & 18.8392 \\
\hline AN-03 & Antiparos & Chatzovounia Mine 1 & Modern & Cer, Goeth & Marble & 2.300 & 0.126 & 18.8412 \\
\hline AN-04A & Antiparos & Agios Georgios Mine 3 & Modern & Gal & Marble & 386.406 & 66.982 & 18.8238 \\
\hline AN-04B & Antiparos & Agios Georgios Mine 4 & Modern & Gal & Marble & 237.798 & 61.638 & 18.8229 \\
\hline PO-01A & Polyaigos & Modern Mine & Modern & Gal, Bar & Marble & 80.570 & 33.227 & 18.8771 \\
\hline PO-01B & Polyaigos & Modern Mine & Modern & Gal, Bar & Marble & 67.629 & 54.612 & 18.8726 \\
\hline PO-01C & Polyaigos & Modern Mine & Modern & Gal, Bar & Marble & 116.004 & 89.208 & 18.8779 \\
\hline ANA-01 & Anaphi & Ntoumparia & Modern & Gal, Spha & Marble & 81.189 & 36.854 & 18.8946 \\
\hline HYM-01 & Hymettus & Kynigos-1 Mine & Modern & Goeth, Cer & Marble & 1.855 & 1.162 & 18.4301 \\
\hline HYM-02 & Hymettus & Hymittos-2 (kamini) & Modern & Goeth, Cer & Marble & 0.000 & 0.191 & 18.4053 \\
\hline HYM-03 & Hymettus & Kynigos-1 Mine & Modern & Goeth, Cer & Marble & 6.301 & 1.024 & 18.4321 \\
\hline
\end{tabular}

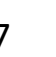
.

.

.

.

.

.
. . . . ,

.
. . . . . . . . . .

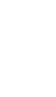

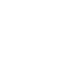

.
. .

$$
\text { . }
$$

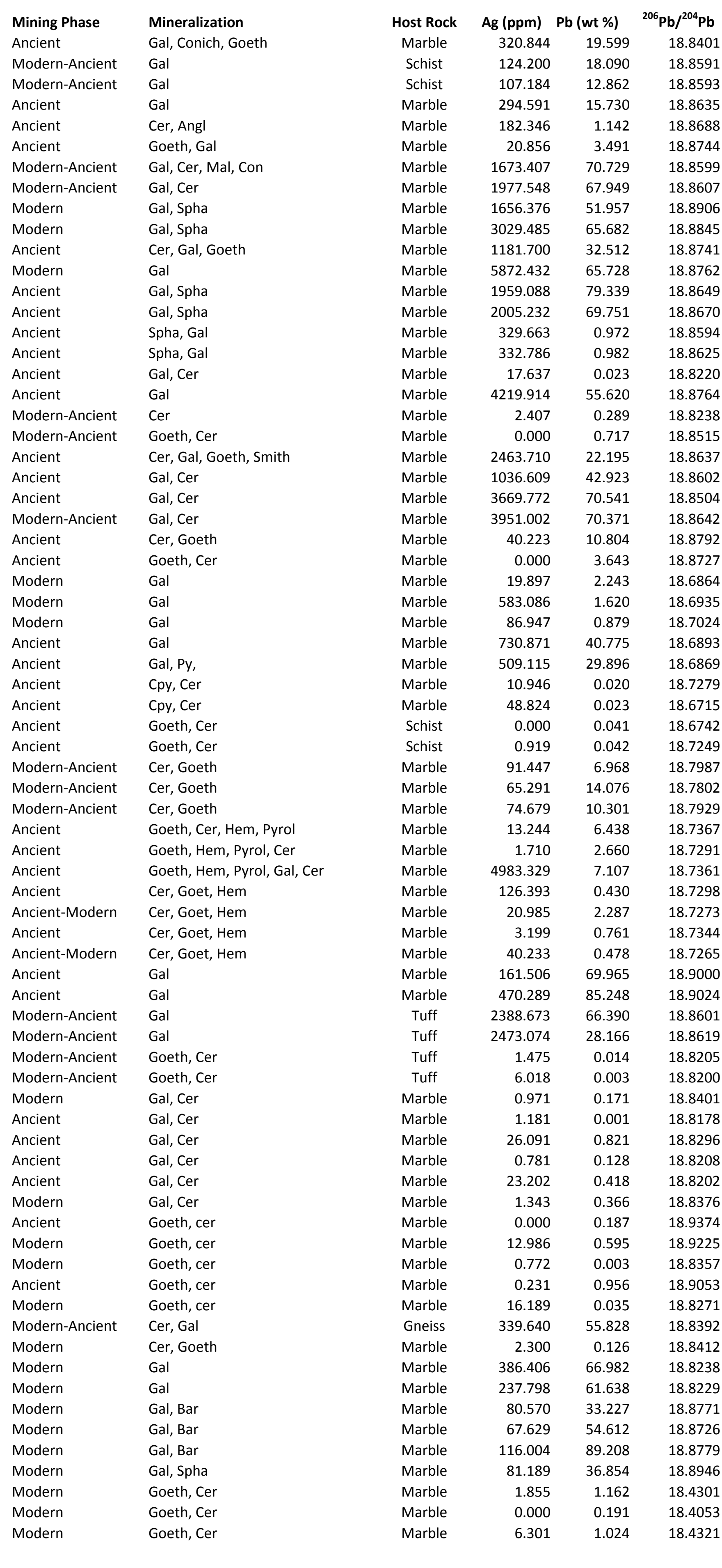




\begin{tabular}{|c|c|c|c|c|c|c|c|c|}
\hline HYM-04 & Hymettus & Hymittos-2 (kamini) & Modern & Goeth, Cer & Marble & 0.715 & 0.259 & 18.4040 \\
\hline PE-01 & Pelion & Gourounotrypa & Ancient & Goeth, cer & Marble & 8.193 & 0.369 & 18.8707 \\
\hline PE-02 & Pelion & Gourounotrypa & Ancient & Goeth, cer & Marble & 13.018 & 1.397 & 18.8701 \\
\hline PE-03A & Pelion & Souvria & Ancient & Goeth, cer & Marble & 2.947 & 0.061 & 18.8796 \\
\hline PE-03B & Pelion & Souvria & Ancient & Goeth, cer & Marble & 11.004 & 0.059 & 18.8785 \\
\hline PE-04 & Pelion & Souvria & Ancient & Goeth, cer & Marble & 10.871 & 0.342 & 18.8696 \\
\hline LES-01 & Lesbos & Argenos & Modern & Gal & Andesite & 154.536 & 37.982 & 18.6284 \\
\hline SAM-01 & Samothrace & Pachia Ammos & Modern & Gal & Granite & 471.108 & 58.564 & 18.3785 \\
\hline MP-01A & Chalkidiki & Mavres Petres & Modern & Gal & Marble & 2825.600 & 82.768 & 18.7966 \\
\hline MP-01B & Chalkidiki & Mavres Petres & Modern & Gal & Marble & 2879.577 & 82.366 & 18.8045 \\
\hline MP-01C & Chalkidiki & Mavres Petres & Modern & Gal & Marble & 2708.115 & 72.417 & 18.8076 \\
\hline OL-01A & Chalkidiki & Olympiada & Modern & Gal & Marble & 1536.102 & 55.023 & 18.7805 \\
\hline OL-01B & Chalkidiki & Olympiada & Modern & Gal & Marble & 1574.803 & 52.449 & 18.7801 \\
\hline OL-02A & Chalkidiki & Olympiada & Ancient & Cer, Fe-Mn & Marble & 291.414 & 0.025 & 18.7878 \\
\hline OL-02B & Chalkidiki & Olympiada & Ancient & Goeth, Cer, Pyrol & Marble & 674.232 & 0.032 & 18.7928 \\
\hline C-01A & Chalkidiki & Stratoni & Modern & Gal, Cer & Marble & 14.247 & 0.195 & 18.8121 \\
\hline$C-01 B$ & Chalkidiki & Stratoni & Modern & Gal, Cer & Marble & 18.475 & 0.190 & 18.8147 \\
\hline C-02 & Chalkidiki & Fterouda & Ancient & Goeth, Cer & Marble & 39.459 & 3.217 & 18.7061 \\
\hline $\mathrm{T}-01$ & Thasos & Acropolis Mine & Ancient & Gal, Cer & Marble & 50.818 & 0.097 & 18.6928 \\
\hline $\mathrm{T}-02$ & Thasos & Rachoni Mine & Ancient & Goeth, Cer & Marble & 44.933 & 2.798 & 18.8502 \\
\hline$T-03$ & Thasos & Sotiros Mine & Ancient & Goeth, Cer & Marble & 8.485 & 1.711 & 18.7992 \\
\hline$T-04$ & Thasos & Koumaria & Ancient & Goeth, Cer & Marble & 2.788 & 0.002 & 18.8010 \\
\hline T-06 & Thasos & Rachoni Mine & Ancient & Goeth, Cer & Marble & 5.967 & 1.779 & 18.8468 \\
\hline T-07 & Thasos & Vouves & Modern & Smith, Cer & Marble & 13.848 & 0.008 & 18.7902 \\
\hline $\mathrm{T}-08$ & Thasos & Vouves & Modern & Goeth, Cer & Marble & 0.233 & 0.164 & 18.7820 \\
\hline $\mathrm{T}-10$ & Thasos & Acropolis Mine & Ancient & Goeth, Cer & Marble & 101.642 & 0.048 & 18.6901 \\
\hline $\mathrm{T}-11$ & Thasos & Acropolis Mine & Ancient & Goeth, Cer & Marble & 2.243 & 0.061 & 18.6886 \\
\hline $\mathrm{T}-12$ & Thasos & Acropolis Mine & Ancient & Goeth, Cer & Marble & 945.059 & 0.040 & 18.6921 \\
\hline D-01 & Kroussia & Kerkini & Ancient & Cer & Marble & 23.655 & 0.912 & 18.7909 \\
\hline D-02 & Kroussia & Agios Markos & Modern & Gal & Gneiss & 1364.079 & 13.735 & 18.8251 \\
\hline D-03 & Kroussia & Agios Markos & Modern & Gal & Gneiss & 214.609 & 13.558 & 18.8260 \\
\hline D-04 & Kroussia & Koulachli Mine & Ancient & Cer & Gneiss & 8.930 & 0.752 & 18.8077 \\
\hline D-05 & Kroussia & Koulachli Mine & Ancient & Cer & Gneiss & 4.733 & 0.095 & 18.8133 \\
\hline D-06 & Kroussia & Koulachli Mine & Ancient & Cer & Gneiss & 18.802 & 0.160 & 18.8224 \\
\hline D-07 & Kroussia & Vathi Ancient Mine & Ancient & Cer & Rhyolite & 0.000 & 0.082 & 18.8632 \\
\hline D-10 & Kroussia & Myriophyto outcrop & Modern Quarry & Goeth, Cer & Marble & 0.700 & 0.021 & 18.3296 \\
\hline LE-01 & Angistron & Lechovo & Ancient-Modern & Cer & Marble & 11.350 & 4.490 & 18.7211 \\
\hline LE-02 & Angistron & Lechovo & Ancient-Modern & Cer & Marble & 182.462 & 8.018 & 18.7250 \\
\hline LE-03 & Angistron & Lechovo & Ancient-Modern & Cer & Marble & 11.793 & 3.839 & 18.7299 \\
\hline LE-04 & Angistron & Lechovo & Ancient-Modern & Cer & Marble & 176.214 & 8.466 & 18.7283 \\
\hline PA-01 & Pangaeon & Nerostria & Modern-Ancient & Goeth, Cer & Granodiorite & 1.324 & 0.008 & 18.7317 \\
\hline PA-02 & Pangaeon & Asimotrypes & Ancient-Modern & Pyr, Apy, Gal. Spha, Cpy & Marble & 9697.459 & 22.400 & 18.7013 \\
\hline PA-02B & Pangaeon & Asimotrypes & Ancient-Modern & Pyr, Apy, Gal. Spha, Cpy & Marble & 9906.324 & 20.114 & 18.7044 \\
\hline PA-03 & Pangaeon & Agia Triada-1 & Ancient & Goeth, Mal, Cer & Marble & 124.429 & 0.302 & 18.7075 \\
\hline PA-04A & Pangaeon & Asimotrypes & Ancient-Modern & Pyr, Apy, Gal. Spha, Cpy & Marble & 5439.100 & 11.364 & 18.7012 \\
\hline PA-04B & Pangaeon & Asimotrypes & Ancient-Modern & Pyr, Apy, Gal. Spha, Cpy & Marble & 5042.224 & 10.575 & 18.6974 \\
\hline PA-05 & Pangaeon & Avgo peak & Ancient-Modern & Goeth, Cer & Marble & 86.924 & 1.851 & 18.7013 \\
\hline PA-06 & Pangaeon & Avgo peak & Ancient-Modern & Goeth, Cer & Marble & 145.377 & 5.704 & 18.6948 \\
\hline PA-07A & Pangaeon & Ofrynio-2 & Ancient & Goeth, Cer & Marble & 20.220 & 1.253 & 18.7919 \\
\hline PA-07B & Pangaeon & Ofrynio-2 & Ancient & Goeth, Cer & Marble & 23.808 & 1.089 & 18.7906 \\
\hline PA-11 & Pangaeon & Asimotrypes & Ancient-Modern & Cer, Goeth & Marble & 31.146 & 0.082 & 18.7051 \\
\hline PA-15 & Pangaeon & Asimotrypes & Ancient-Modern & Gal & Marble & 7726.971 & 20.137 & 18.6936 \\
\hline SY-04 & Pangaeon & Kokkinochoma-1 Symvolon & Ancient & Goeth, Cer & Marble & 10.061 & 0.007 & 18.7062 \\
\hline PK-01 & Palaea Kavala & Agia Eleni Mine & Ancient & Cer, Goeth, Hem & Marble & 114.442 & 4.582 & 18.7606 \\
\hline PK-02 & Palaea Kavala & Agia Eleni Mine & Ancient & Cer, Goeth, Hem & Marble & 147.384 & 3.908 & 18.7666 \\
\hline PK-03 & Palaea Kavala & Agia Eleni Mine & Ancient & Cer, Goeth, Hem & Marble & 140.134 & 5.517 & 18.7675 \\
\hline PK-04 & Palaea Kavala & Agia Eleni Mine & Ancient & Cer, Goeth, Hem & Marble & 57.137 & 5.250 & 18.7680 \\
\hline PK-06 & Palaea Kavala & Mavri Trypa Mine & Ancient & Cer & Marble & 95.320 & 0.910 & 18.7565 \\
\hline PK-07 & Palaea Kavala & Lazaros-1 Mine & Ancient & Cer & Marble & 213.268 & 4.684 & 18.7643 \\
\hline PK-08 & Palaea Kavala & Lazaros-1 Mine & Ancient & Cer & Marble & 147.120 & 0.177 & 18.7570 \\
\hline PK-09 & Palaea Kavala & Peristerionas Mine & Ancient & Cer & Marble & 80.467 & 13.026 & 18.7652 \\
\hline PK-11 & Palaea Kavala & Kel-Tepe & Ancient & Goeth, Cer & Marble & 58.591 & 9.665 & 18.7595 \\
\hline THE-01 & Thermes & Loutra & Modern & Gal & Marble & 13.933 & 0.010 & 18.6328 \\
\hline THE-02 & Thermes & Razul & Modern & Gal & Marble & 52.245 & 19.075 & 18.7138 \\
\hline THE-03 & Thermes & Razul & Modern & Gal & Marble & 3.735 & 0.004 & 18.7146 \\
\hline KIR-01 & Kirki & Saint-Philippos & Modern & Gal & Andesite & 949.152 & 1.998 & 18.7177 \\
\hline KIR-02 & Kirki & Saint-Philippos & Modern & Gal-Cpy & Andesite & 97.448 & 0.538 & 18.7155 \\
\hline KIR-03 & Kirki & Saint-Philippos & Modern & Gal-Cpy & Andesite & 1044.842 & 0.328 & 18.7170 \\
\hline KIR-04 & Kirki & Saint-Philippos & Modern & Gal-Cpy & Andesite & 371.873 & 19.810 & 18.7146 \\
\hline SAP-01 & Sappes & Sappes & Modern & Gal & Diorite & 0.396 & 0.040 & 18.7549 \\
\hline SAP-02 & Sappes & Sappes & Modern & Gal & Diorite & 0.000 & 0.009 & 18.8143 \\
\hline AIS-01 & Aisymi & Aisymi & Modern & Gal & Marble & 66.164 & 2.040 & 18.7430 \\
\hline NED-01 & Neda & Neda & Modern & Gal & Marble & 38.667 & 19.581 & 18.7527 \\
\hline NED-02 & Neda & Neda & Modern & Gal & Marble & 45.473 & 29.177 & 18.74 \\
\hline
\end{tabular}


NED-03 Neda

PEF-02 Pefkos
Neda

Pefkos
Modern

Modern
Gal

Gal
Marble

Rhyolite
17.677

1.300

7.502

0.112

18.7443

18.7472 


\begin{tabular}{|c|c|c|c|c|c|c|c|c|c|c|c|c|}
\hline 2SD & ${ }^{207} \mathrm{~Pb} /{ }^{204} \mathrm{~Pb}$ & 2SD & ${ }^{208} \mathrm{~Pb} /{ }^{204} \mathrm{~Pb}$ & 2SD & ${ }^{204} \mathrm{~Pb} /{ }^{206} \mathrm{~Pb}$ & 2SD & ${ }^{207} \mathrm{~Pb} /{ }^{206} \mathrm{~Pb}$ & 2SD & ${ }^{208} \mathrm{~Pb} /{ }^{206} \mathrm{~Pb}$ & 2SD & $\mathbf{x}$ & y \\
\hline 0.0007 & 15.6852 & 0.0006 & 38.820 & 0.002 & 0.0531 & 0.0007 & 0.83254 & 0.00001 & 2.06048 & 0.00003 & $37^{\circ} 42^{\prime} 57.7866^{\prime \prime N}$ & $24^{\circ} 00^{\prime} 49.5334^{\prime \prime} \mathrm{E}$ \\
\hline 0.0010 & 15.6938 & 0.0011 & 38.939 & 0.003 & 0.0530 & 0.0010 & 0.83216 & 0.00001 & 2.06471 & 0.00008 & $37^{\circ} 47^{\prime} 27.5781^{\prime \prime N}$ & $24^{\circ} 04^{\prime} 55.6097^{\prime \prime} \mathrm{E}$ \\
\hline 0.0008 & 15.6939 & 0.0008 & 38.938 & 0.003 & 0.0530 & 0.0008 & 0.83216 & 0.00001 & 2.06471 & 0.00005 & $37^{\circ} 47^{\prime} 27.5781^{\prime \prime N}$ & $24^{\circ} 04^{\prime} 55.6097^{\prime \prime} \mathrm{E}$ \\
\hline 0.0011 & 15.6936 & 0.0008 & 38.884 & 0.002 & 0.0530 & 0.0011 & 0.83194 & 0.00003 & 2.06127 & 0.00008 & $37^{\circ} 45^{\prime} 42.8612^{\prime \prime} \mathrm{N}$ & $23^{\circ} 59^{\prime} 28.2221^{\prime \prime} \mathrm{E}$ \\
\hline 0.0008 & 15.6925 & 0.0009 & 38.865 & 0.003 & 0.0530 & 0.0008 & 0.83165 & 0.00001 & 2.05975 & 0.00009 & $37^{\circ} 43^{\prime} 34.3682^{\prime \prime} \mathrm{N}$ & $24^{\circ} 01^{\prime} 58.0272^{\prime \prime} \mathrm{E}$ \\
\hline 0.0009 & 15.6916 & 0.0011 & 38.884 & 0.004 & 0.0530 & 0.0009 & 0.83136 & 0.00002 & 2.06013 & 0.00010 & $37^{\circ} 45^{\prime} 11.1933^{\prime \prime} \mathrm{N}$ & $24^{\circ} 00^{\prime} 06.0348^{\prime \prime} \mathrm{E}$ \\
\hline 0.0008 & 15.6837 & 0.0009 & 38.825 & 0.003 & 0.0530 & 0.0008 & 0.83158 & 0.00001 & 2.05856 & 0.00007 & $37^{\circ} 43^{\prime} 42.7689^{\prime \prime} \mathrm{N}$ & $24^{\circ} 00^{\prime} 38.2815^{\prime \prime} \mathrm{E}$ \\
\hline 0.0007 & 15.6872 & 0.0007 & 38.824 & 0.002 & 0.0530 & 0.0007 & 0.83175 & 0.00001 & 2.05845 & 0.00005 & $37^{\circ} 43^{\prime} 34.3682^{\prime \prime N}$ & $24^{\circ} 01^{\prime} 58.0272^{\prime \prime} \mathrm{E}$ \\
\hline 0.0032 & 15.7093 & 0.0026 & 38.938 & 0.006 & 0.0529 & 0.0032 & 0.83160 & 0.00001 & 2.06122 & 0.00006 & $37^{\circ} 45^{\prime} 36.1342^{\prime \prime} \mathrm{N}$ & $24^{\circ} 01^{\prime} 59.6156^{\prime \prime} \mathrm{E}$ \\
\hline 0.0019 & 15.7034 & 0.0016 & 38.923 & 0.003 & 0.0530 & 0.0019 & 0.83155 & 0.00001 & 2.06112 & 0.00005 & $37^{\circ} 45^{\prime} 35.8797^{\prime \prime} \mathrm{N}$ & $24^{\circ} 01^{\prime} 57.0971^{\prime \prime} \mathrm{E}$ \\
\hline 0.0007 & 15.6921 & 0.0006 & 38.878 & 0.002 & 0.0530 & 0.0007 & 0.83141 & 0.00001 & 2.05984 & 0.00008 & $37^{\circ} 45^{\prime} 11.1933 " \mathrm{~N}$ & $24^{\circ} 00^{\prime} 06.0347^{\prime \prime} \mathrm{E}$ \\
\hline 0.0008 & 15.6918 & 0.0007 & 38.893 & 0.002 & 0.0530 & 0.0008 & 0.83131 & 0.00001 & 2.06040 & 0.00005 & $37^{\circ} 45^{\prime} 35.5808^{\prime \prime} \mathrm{N}$ & $24^{\circ} 02^{\prime} 01.0620^{\prime \prime} \mathrm{E}$ \\
\hline 0.0007 & 15.6901 & 0.0006 & 38.838 & 0.002 & 0.0530 & 0.0007 & 0.83171 & 0.00001 & 2.05874 & 0.00004 & $37^{\circ} 43^{\prime} 34.1947 " \mathrm{~N}$ & $24^{\circ} 02^{\prime} 01.7645^{\prime \prime} \mathrm{E}$ \\
\hline 0.0012 & 15.6905 & 0.0011 & 38.837 & 0.003 & 0.0530 & 0.0012 & 0.83164 & 0.00001 & 2.05850 & 0.00006 & $37^{\circ} 43^{\prime} 34.1947^{\prime \prime N}$ & $24^{\circ} 02^{\prime} 01.7645^{\prime \prime} \mathrm{E}$ \\
\hline 0.0010 & 15.6845 & 0.0010 & 38.857 & 0.003 & 0.0530 & 0.0010 & 0.83166 & 0.00001 & 2.06033 & 0.00009 & $37^{\circ} 43^{\prime} 34.4729^{\prime \prime} \mathrm{N}$ & $24^{\circ} 02^{\prime} 01.3349^{\prime \prime}$ \\
\hline 0.0006 & 15.6865 & 0.0005 & 38.860 & 0.001 & 0.0530 & 0.0006 & 0.83163 & 0.00001 & 2.06021 & 0.00002 & $37^{\circ} 43^{\prime} 34.4729^{\prime \prime} \mathrm{N}$ & $24^{\circ} 02^{\prime} 01.3349^{\prime \prime} \mathrm{E}$ \\
\hline 0.0007 & 15.6795 & 0.0007 & 38.858 & 0.002 & 0.0531 & 0.0007 & 0.83305 & 0.00001 & 2.06450 & 0.00006 & $37^{\circ} 43^{\prime} 13.2700^{\prime \prime N}$ & $24^{\circ} 00^{\prime} 41.5551^{\prime \prime} \mathrm{E}$ \\
\hline 0.0009 & 15.6941 & 0.0010 & 38.913 & 0.003 & 0.0530 & 0.0009 & 0.83142 & 0.00002 & 2.06148 & 0.00010 & $37^{\circ} 40^{\prime} 51.8589^{\prime \prime} \mathrm{N}$ & $24^{\circ} 04^{\prime} 03.8284^{\prime \prime} \mathrm{E}$ \\
\hline 0.0005 & 15.6925 & 0.0004 & 38.882 & 0.001 & 0.0531 & 0.0005 & 0.83367 & 0.00001 & 2.06561 & 0.00003 & $37^{\circ} 40^{\prime} 51.6458^{\prime \prime} \mathrm{N}$ & $24^{\circ} 01^{\prime} 02.4408^{\prime \prime} \mathrm{E}$ \\
\hline 0.0007 & 15.6850 & 0.0006 & 38.874 & 0.002 & 0.0530 & 0.0007 & 0.83202 & 0.00001 & 2.06207 & 0.00002 & $37^{\circ} 42^{\prime} 41.4758^{\prime \prime} \mathrm{N}$ & $24^{\circ} 01^{\prime} 27.2640^{\prime \prime} \mathrm{E}$ \\
\hline 0.0025 & 15.6861 & 0.0031 & 38.860 & 0.010 & 0.0530 & 0.0025 & 0.83154 & 0.00005 & 2.06003 & 0.00023 & $37^{\circ} 45^{\prime} 11.1933^{\prime \prime} \mathrm{N}$ & $24^{\circ} 00^{\prime} 06.0347^{\prime \prime} \mathrm{E}$ \\
\hline 0.0006 & 15.6995 & 0.0006 & 38.889 & 0.002 & 0.0530 & 0.0006 & 0.83240 & 0.00001 & 2.06195 & 0.00004 & $37^{\circ} 41^{\prime} 58.1481^{\prime \prime} \mathrm{N}$ & $24^{\circ} 00^{\prime} 38.6262^{\prime \prime} \mathrm{E}$ \\
\hline 0.0009 & 15.6946 & 0.0008 & 38.886 & 0.003 & 0.0530 & 0.0009 & 0.83256 & 0.00001 & 2.06280 & 0.00007 & $37^{\circ} 41^{\prime} 37.6138^{\prime \prime} \mathrm{N}$ & $24^{\circ} 01^{\prime} 36.2949^{\prime \prime} \mathrm{E}$ \\
\hline 0.0015 & 15.6840 & 0.0014 & 38.830 & 0.004 & 0.0530 & 0.0015 & 0.83143 & 0.00002 & 2.05841 & 0.00010 & $37^{\circ} 44^{\prime} 02.4144^{\prime \prime} \mathrm{N}$ & $24^{\circ} 01^{\prime} 10.9848^{\prime \prime} \mathrm{E}$ \\
\hline 0.0007 & 15.6896 & 0.0006 & 38.858 & 0.002 & 0.0530 & 0.0007 & 0.83105 & 0.00001 & 2.05827 & 0.00003 & $37^{\circ} 46^{\prime} 10.1912^{\prime \prime N}$ & $23^{\circ} 59^{\prime} 53.8461 " \mathrm{E}$ \\
\hline 0.0009 & 15.6942 & 0.0007 & 38.921 & 0.002 & 0.0530 & 0.0009 & 0.83159 & 0.00001 & 2.06231 & 0.00005 & $37^{\circ} 44^{\prime} 17.0548^{\prime \prime} \mathrm{N}$ & $24^{\circ} 03^{\prime} 15.7263^{\prime \prime} \mathrm{E}$ \\
\hline 0.0006 & 15.6977 & 0.0005 & 38.908 & 0.001 & 0.0535 & 0.0006 & 0.84006 & 0.00001 & 2.08217 & 0.00003 & $38^{\circ} 06^{\prime} 49.4600^{\prime \prime} \mathrm{N}$ & $24^{\circ} 30^{\prime} 47.7804^{\prime \prime} \mathrm{E}$ \\
\hline 0.0006 & 15.6957 & 0.0005 & 38.912 & 0.002 & 0.0535 & 0.0006 & 0.83963 & 0.00001 & 2.08156 & 0.00003 & $38^{\circ} 06^{\prime} 48.7526^{\prime \prime N}$ & $24^{\circ} 30^{\prime} 40.3656^{\prime \prime} \mathrm{E}$ \\
\hline 0.0006 & 15.7009 & 0.0005 & 38.927 & 0.002 & 0.0535 & 0.0006 & 0.83952 & 0.00001 & 2.08141 & 0.00003 & $38^{\circ} 06^{\prime} 48.7526^{\prime \prime N}$ & $24^{\circ} 30^{\prime} 40.3656^{\prime \prime} \mathrm{E}$ \\
\hline 0.0007 & 15.7011 & 0.0006 & 38.916 & 0.002 & 0.0535 & 0.0007 & 0.84012 & 0.00001 & 2.08230 & 0.00004 & $38^{\circ} 06^{\prime} 15.6060^{\prime \prime} \mathrm{N}$ & $24^{\circ} 30^{\prime} 38.9232^{\prime \prime} \mathrm{E}$ \\
\hline 0.0006 & 15.6994 & 0.0005 & 38.913 & 0.002 & 0.0535 & 0.0006 & 0.84013 & 0.00001 & 2.08242 & 0.00005 & $38^{\circ} 06^{\prime} 17.2800^{\prime \prime} \mathrm{N}$ & $24^{\circ} 30^{\prime} 39.5208^{\prime \prime} \mathrm{E}$ \\
\hline 0.0008 & 15.6943 & 0.0007 & 38.947 & 0.002 & 0.0534 & 0.0008 & 0.83802 & 0.00001 & 2.07966 & 0.00005 & $38^{\circ} 08^{\prime} 32.1909^{\prime \prime N}$ & $24^{\circ} 32^{\prime} 14.6206^{\prime \prime} \mathrm{E}$ \\
\hline 0.0006 & 15.6958 & 0.0005 & 38.669 & 0.001 & 0.0536 & 0.0006 & 0.84063 & 0.00001 & 2.07105 & 0.00004 & $38^{\circ} 08^{\prime} 32.1909^{\prime \prime N}$ & $24^{\circ} 32^{\prime} 14.6206^{\prime \prime} \mathrm{E}$ \\
\hline 0.0009 & 15.6977 & 0.0008 & 38.675 & 0.002 & 0.0535 & 0.0009 & 0.84061 & 0.00001 & 2.07107 & 0.00004 & $38^{\circ} 08^{\prime} 38.4173^{\prime \prime} \mathrm{N}$ & $24^{\circ} 26^{\prime} 52.0365^{\prime \prime} \mathrm{E}$ \\
\hline 0.0007 & 15.6915 & 0.0007 & 38.941 & 0.002 & 0.0534 & 0.0007 & 0.83801 & 0.00001 & 2.07963 & 0.00006 & $38^{\circ} 08^{\prime} 38.4173^{\prime \prime} \mathrm{N}$ & $24^{\circ} 26^{\prime} 52.0365^{\prime \prime} \mathrm{E}$ \\
\hline 0.0010 & 15.7059 & 0.0009 & 38.933 & 0.003 & 0.0532 & 0.0010 & 0.83549 & 0.00001 & 2.07112 & 0.00004 & $38^{\circ} 15^{\prime} 00.9759^{\prime \prime} \mathrm{N}$ & $24^{\circ} 10^{\prime} 14.4010^{\prime \prime} \mathrm{E}$ \\
\hline 0.0011 & 15.7004 & 0.0010 & 38.912 & 0.003 & 0.0532 & 0.0011 & 0.83600 & 0.00001 & 2.07202 & 0.00005 & $38^{\circ} 15^{\prime} 11.1816^{\prime \prime} \mathrm{N}$ & $24^{\circ} 10^{\prime} 15.4272^{\prime \prime} \mathrm{E}$ \\
\hline 0.0007 & 15.7048 & 0.0007 & 38.930 & 0.002 & 0.0532 & 0.0007 & 0.83569 & 0.00001 & 2.07155 & 0.00005 & $38^{\circ} 15^{\prime} 19.3932^{\prime \prime N}$ & $24^{\circ} 10^{\prime} 30.7668^{\prime \prime} \mathrm{E}$ \\
\hline 0.0009 & 15.7141 & 0.0010 & 38.960 & 0.003 & 0.0534 & 0.0009 & 0.83869 & 0.00001 & 2.07940 & 0.00011 & $37^{\circ} 00^{\prime} 48.9132 " \mathrm{~N}$ & $24^{\circ} 42^{\prime} 49.2732^{\prime \prime} \mathrm{E}$ \\
\hline 0.0006 & 15.7045 & 0.0005 & 38.954 & 0.002 & 0.0534 & 0.0006 & 0.83851 & 0.00001 & 2.07985 & 0.00002 & $37^{\circ} 00^{\prime} 45.6151 " \mathrm{~N}$ & $24^{\circ} 42^{\prime} 49.0187^{\prime \prime}$ \\
\hline 0.0005 & 15.7040 & 0.0004 & 38.951 & 0.001 & 0.0534 & 0.0005 & 0.83817 & 0.00001 & 2.07894 & 0.00002 & $37^{\circ} 00^{\prime} 22.4271 " \mathrm{~N}$ & $24^{\circ} 42^{\prime} 23.6622^{\prime \prime} \mathrm{E}$ \\
\hline 0.0005 & 15.7048 & 0.0004 & 38.955 & 0.001 & 0.0534 & 0.0005 & 0.83850 & 0.00001 & 2.07987 & 0.00002 & $36^{\circ} 58^{\prime} 32.6352^{\prime \prime ~ N}$ & $24^{\circ} 41^{\prime} 21.3432^{\prime \prime} \mathrm{E}$ \\
\hline 0.0005 & 15.7018 & 0.0005 & 38.950 & 0.002 & 0.0534 & 0.0005 & 0.83843 & 0.00001 & 2.07987 & 0.00003 & $36^{\circ} 58^{\prime} 50.7396^{\prime \prime} \mathrm{N}$ & $24^{\circ} 41^{\prime} 25.9548^{\prime \prime} \mathrm{E}$ \\
\hline 0.0006 & 15.7058 & 0.0006 & 38.961 & 0.002 & 0.0534 & 0.0006 & 0.83833 & 0.00001 & 2.07964 & 0.00004 & $37^{\circ} 00^{\prime} 48.9132^{\prime \prime} \mathrm{N}$ & $24^{\circ} 42^{\prime} 49.2732^{\prime \prime} \mathrm{E}$ \\
\hline 0.0007 & 15.7009 & 0.0007 & 38.946 & 0.002 & 0.0534 & 0.0007 & 0.83846 & 0.00001 & 2.07974 & 0.00006 & $36^{\circ} 58^{\prime} 32.6352^{\prime \prime} \mathrm{N}$ & $24^{\circ} 41^{\prime} 21.3432^{\prime \prime} \mathrm{E}$ \\
\hline 0.0008 & 15.7010 & 0.0008 & 39.009 & 0.003 & 0.0529 & 0.0008 & 0.83076 & 0.00001 & 2.06400 & 0.00006 & $37^{\circ} 11^{\prime} 12.1704^{\prime \prime} \mathrm{N}$ & $24^{\circ} 30^{\prime} 06.5340^{\prime \prime} \mathrm{E}$ \\
\hline 0.0008 & 15.7030 & 0.0007 & 39.014 & 0.003 & 0.0529 & 0.0008 & 0.83075 & 0.00001 & 2.06394 & 0.00007 & $37^{\circ} 11^{\prime} 12.1704^{\prime \prime} \mathrm{N}$ & $24^{\circ} 30^{\prime} 06.5340^{\prime \prime} \mathrm{E}$ \\
\hline 0.0006 & 15.6892 & 0.0006 & 39.007 & 0.002 & 0.0530 & 0.0006 & 0.83188 & 0.00001 & 2.06829 & 0.00003 & $36^{\circ} 42^{\prime} 23.5944^{\prime \prime} \mathrm{N}$ & $24^{\circ} 20^{\prime} 47.9112^{\prime \prime} \mathrm{E}$ \\
\hline 0.0007 & 15.6896 & 0.0008 & 39.008 & 0.002 & 0.0530 & 0.0007 & 0.83181 & 0.00001 & 2.06810 & 0.00005 & $36^{\circ} 42^{\prime} 23.5944^{\prime \prime} \mathrm{N}$ & $24^{\circ} 20^{\prime} 47.9112^{\prime \prime} \mathrm{E}$ \\
\hline 0.0006 & 15.6935 & 0.0006 & 38.971 & 0.002 & 0.0531 & 0.0006 & 0.83387 & 0.00001 & 2.07071 & 0.00004 & $36^{\circ} 43^{\prime} 58.2240^{\prime \prime} \mathrm{N}$ & $24^{\circ} 22^{\prime} 02.5392^{\prime \prime} \mathrm{E}$ \\
\hline 0.0005 & 15.6954 & 0.0005 & 38.973 & 0.001 & 0.0531 & 0.0005 & 0.83398 & 0.00001 & 2.07082 & 0.00004 & $36^{\circ} 43^{\prime} 58.2240^{\prime \prime} \mathrm{N}$ & $24^{\circ} 22^{\prime} 02.5392^{\prime \prime} \mathrm{E}$ \\
\hline 0.0016 & 15.7186 & 0.0012 & 39.103 & 0.003 & 0.0531 & 0.0016 & 0.83431 & 0.00002 & 2.07551 & 0.0 & $37^{\circ} 24^{\prime} 50.1300^{\prime \prime N}$ & $24^{\circ} 57^{\prime} 50.3700^{\prime \prime} \mathrm{E}$ \\
\hline 0.0007 & 15.7099 & 0.0007 & 39.045 & 0.002 & 0.0531 & 0.0007 & 0.83486 & 0.00001 & 2.07495 & 0.00004 & $37^{\circ} 22^{\prime} 29.9928^{\prime \prime N}$ & $24^{\circ} 54^{\prime} 15.0552^{\prime \prime} \mathrm{E}$ \\
\hline 0.0010 & 15.7141 & 0.0009 & 39.054 & 0.006 & 0.0531 & 0.0010 & 0.83455 & 0.00001 & 2.07419 & 0.0 & $37^{\circ} 22^{\prime} 28.8372^{\prime \prime N}$ & $24^{\circ} 54^{\prime} 16.1100^{\prime \prime} \mathrm{E}$ \\
\hline 0.0016 & 15.7114 & 0.0014 & 39.056 & 0.003 & 0.0531 & 0.0016 & 0.83479 & 0.00002 & 2.07514 & 0.00005 & $37^{\circ} 22^{\prime} 29.9928^{\prime \prime N}$ & $24^{\circ} 54^{\prime} 15.0552^{\prime \prime} \mathrm{E}$ \\
\hline 0.0019 & 15.7140 & 0.0009 & 39.064 & 0.004 & 0.0531 & 0.0019 & 0.83494 & 0.00001 & 2.07559 & 0.00004 & $37^{\circ} 22^{\prime} 29.9928^{\prime \prime N}$ & $24^{\circ} 54^{\prime} 15.0552^{\prime \prime} \mathrm{E}$ \\
\hline 0.0010 & 15.7196 & 0.0011 & 39.086 & 0.003 & 0.0531 & 0.0010 & 0.83450 & 0.00002 & 2.07494 & 0.00008 & $37^{\circ} 22^{\prime} 29.9928^{\prime \prime N}$ & $24^{\circ} 54^{\prime} 15.0552^{\prime \prime} \mathrm{E}$ \\
\hline 0.0010 & 15.7013 & 0.0009 & 39.025 & 0.003 & 0.0528 & 0.0010 & 0.82913 & 0.00001 & 2.06074 & 0.00005 & $37^{\circ} 18^{\prime} 07.3233^{\prime \prime} \mathrm{N}$ & $24^{\circ} 21^{\prime} 51.8554^{\prime \prime} \mathrm{E}$ \\
\hline 0.0007 & 15.7018 & 0.0006 & 39.024 & 0.002 & 0.0528 & 0.0007 & 0.82980 & 0.00001 & 2.06227 & 0.00004 & $37^{\circ} 18^{\prime} 03.8231 " \mathrm{~N}$ & $24^{\circ} 21^{\prime} 57.7715^{\prime \prime} \mathrm{E}$ \\
\hline 0.0007 & 15.7024 & 0.0007 & 39.008 & 0.002 & 0.0531 & 0.0007 & 0.83367 & 0.00001 & 2.07098 & 0.00003 & $37^{\circ} 22^{\prime} 53.2584^{\prime \prime} \mathrm{N}$ & $24^{\circ} 25^{\prime} 47.5470^{\prime \prime} \mathrm{E}$ \\
\hline 0.0016 & 15.7009 & 0.0015 & 39.008 & 0.005 & 0.0529 & 0.0016 & 0.83050 & 0.00002 & 2.06330 & 0.00010 & $37^{\circ} 21^{\prime} 29.9736^{\prime \prime} \mathrm{N}$ & $24^{\circ} 23^{\prime} 22.3764^{\prime \prime} \mathrm{E}$ \\
\hline 0.0009 & 15.7196 & 0.0007 & 39.123 & 0.002 & 0.0531 & 0.0009 & 0.83494 & 0.00001 & 2.07805 & 0.00003 & $37^{\circ} 22^{\prime} 44.6990^{\prime \prime} \mathrm{N}$ & $24^{\circ} 27^{\prime} 21.9268^{\prime \prime} \mathrm{E}$ \\
\hline 0.0006 & 15.7258 & 0.0005 & 39.170 & 0.001 & 0.0531 & 0.0006 & 0.83475 & 0.00001 & 2.07920 & 0.00003 & $37^{\circ} 00^{\prime} 10.7244 " \mathrm{~N}$ & $25^{\circ} 02^{\prime} 00.1500^{\prime \prime} \mathrm{E}$ \\
\hline 0.0008 & 15.7259 & 0.0008 & 39.173 & 0.002 & 0.0531 & 0.0008 & 0.83466 & 0.00001 & 2.07911 & 0.00006 & $36^{\circ} 59^{\prime} 41.0712^{\prime \prime} \mathrm{N}$ & $25^{\circ} 03^{\prime} 21.9744^{\prime \prime} \mathrm{E}$ \\
\hline 0.0007 & 15.7190 & 0.0006 & 39.118 & 0.002 & 0.0531 & 0.0007 & 0.83506 & 0.00001 & 2.07816 & 0.00003 & $36^{\circ} 59^{\prime} 07.6596^{\prime \prime N}$ & $25^{\circ} 01^{\prime} 49.6668^{\prime \prime} \mathrm{E}$ \\
\hline 0.0007 & 15.7181 & 0.0006 & 39.117 & 0.002 & 0.0531 & 0.0007 & 0.83505 & 0.00001 & 2.07820 & 0.00006 & $36^{\circ} 59^{\prime} 07.6596 " \mathrm{~N}$ & $25^{\circ} 01^{\prime} 49.6668^{\prime \prime} \mathrm{E}$ \\
\hline 0.0006 & 15.6974 & 0.0006 & 39.015 & 0.001 & 0.0530 & 0.0006 & 0.83156 & 0.00001 & 2.06680 & 0.00003 & $36^{\circ} 47^{\prime} 07.8527^{\prime \prime} \mathrm{N}$ & $24^{\circ} 36^{\prime} 43.7007^{\prime \prime} \mathrm{E}$ \\
\hline 0.0009 & 15.6924 & 0.0011 & 39.003 & 0.004 & 0.0530 & 0.0009 & 0.83149 & 0.00002 & 2.06658 & 0.00012 & $36^{\circ} 47^{\prime} 07.6344^{\prime \prime} \mathrm{N}$ & $24^{\circ} 36^{\prime} 43.7904^{\prime \prime} \mathrm{E}$ \\
\hline 0.0009 & 15.6974 & 0.0008 & 39.017 & 0.002 & 0.0530 & 0.0009 & 0.83152 & 0.00001 & 2.06677 & 0.00004 & $36^{\circ} 47^{\prime} 07.8527^{\prime \prime} \mathrm{N}$ & $24^{\circ} 36^{\prime} 43.7007^{\prime \prime} \mathrm{E}$ \\
\hline 0.0011 & 15.7009 & 0.0014 & 39.031 & 0.004 & 0.0529 & 0.0011 & 0.83098 & 0.00002 & 2.06566 & 0.00011 & $36^{\circ} 21^{\prime} 59.5620^{\prime \prime} \mathrm{N}$ & $25^{\circ} 45^{\prime} 45.8244^{\prime \prime} \mathrm{E}$ \\
\hline 0.0015 & 15.6851 & 0.0013 & 38.597 & 0.004 & 0.0543 & 0.0015 & 0.85105 & 0.00001 & 2.09420 & 0.00005 & $37^{\circ} 59^{\prime} 58.5700^{\prime \prime N}$ & $23^{\circ} 50^{\prime} 12.4600^{\prime \prime} \mathrm{E}$ \\
\hline 0.0007 & 15.6876 & 0.0007 & 38.575 & 0.002 & 0.0543 & 0.0007 & 0.85233 & 0.00001 & 2.09587 & 0.00004 & $37^{\circ} 58^{\prime} 58.6619^{\prime \prime N}$ & $23^{\circ} 50^{\prime} 28.0622^{\prime \prime} \mathrm{E}$ \\
\hline 0.0006 & 15.6858 & 0.0005 & 38.597 & 0.001 & 0.0543 & 0.0006 & 0.85100 & 0.00001 & 2.09404 & 0.00003 & $37^{\circ} 59^{\prime} 58.5700^{\prime \prime N}$ & $23^{\circ} 50^{\prime} 12.4600^{\prime \prime} \mathrm{E}$ \\
\hline
\end{tabular}




\begin{tabular}{|c|c|c|c|c|c|c|c|c|c|c|}
\hline 0.0006 & 15.6854 & 0.0006 & 38.574 & 0.001 & 0.0543 & 0.0006 & 0.85227 & 0.00001 & 2.09599 & 00003 \\
\hline 0.0007 & 15.7090 & 0.0006 & 39.046 & 0.001 & 0.0530 & 0.0007 & 0.83246 & 0.00001 & 2.06912 & 0.00003 \\
\hline 0.0006 & 15.7090 & 0.0006 & 39.048 & 0.002 & 0.0530 & 0.0006 & 0.83248 & 0.00001 & 2.06935 & 0.00003 \\
\hline 0.0008 & 15.7127 & 0.0007 & 39.067 & 0.002 & 0.0530 & 0.0008 & 0.83225 & 0.00001 & 2.06930 & 0.00003 \\
\hline 0.0006 & 15.7134 & 0.0005 & 39.070 & 0.001 & 0.0530 & 0.0006 & 0.83234 & 0.00001 & 2.06955 & 0.00002 \\
\hline 0.0007 & 15.7112 & 0.0005 & 39.058 & 0.002 & 0.0530 & 0.0007 & 0.83262 & 0.00001 & 2.06993 & 0.00002 \\
\hline 0.0008 & 15.6922 & 0.0007 & 39.010 & 0.002 & 0.0537 & 0.0008 & 0.84237 & 0.00001 & 2.09412 & 0.00004 \\
\hline 0.0007 & 15.6730 & 0.0006 & 38.538 & 0.002 & 0.0544 & 0.0007 & 0.85278 & 0.00001 & 2.09688 & 0.00003 \\
\hline 0.0007 & 15.6656 & 0.0007 & 38.889 & 0.002 & 0.0532 & 0.0007 & 0.83343 & 0.00001 & 2.06895 & 0.00003 \\
\hline 0.0007 & 15.6684 & 0.0006 & 38.900 & 0.002 & 0.0532 & 0.0007 & 0.83323 & 0.00001 & 2.06867 & 0.00003 \\
\hline 0.0007 & 15.6707 & 0.0007 & 38.903 & 0.002 & 0.0532 & 0.0007 & 0.83322 & 0.00001 & 2.06855 & 0.00004 \\
\hline 0.0008 & 15.6760 & 0.0008 & 38.877 & 0.003 & 0.0532 & 0.0008 & 0.83472 & 0.00001 & 2.07005 & 0.00007 \\
\hline 0.0006 & 15.6751 & 0.0007 & 38.872 & 0.002 & 0.0532 & 0.0006 & 0.83467 & 0.00001 & 2.06986 & 0.00004 \\
\hline 0.0005 & 15.6790 & 0.0004 & 38.887 & 0.001 & 0.0532 & 0.0005 & 0.83453 & 0.00001 & 2.06978 & 0.00002 \\
\hline 0.0007 & 15.6836 & 0.0006 & 38.897 & 0.002 & 0.0532 & 0.0007 & 0.83456 & 0.00001 & 2.06979 & 0.00003 \\
\hline 0.0013 & 15.6755 & 0.0011 & 38.920 & 0.003 & 0.0532 & 0.0013 & 0.83326 & 0.00001 & 2.06883 & 0.00004 \\
\hline 0.0006 & 15.6733 & 0.0005 & 38.920 & 0.002 & 0.0532 & 0.0006 & 0.83303 & 0.00001 & 2.06860 & 0.00003 \\
\hline 0.0009 & 15.6712 & 0.0009 & 38.835 & 0.003 & 0.0535 & 0.0009 & 0.83777 & 0.00001 & 2.07602 & 0.00006 \\
\hline 0.0005 & 15.6842 & 0.0005 & 38.869 & 0.001 & 0.0535 & 0.0005 & 0.83905 & 0.00001 & 2.07935 & 0.00003 \\
\hline 0.0006 & 15.6898 & 0.0006 & 38.991 & 0.002 & 0.0530 & 0.0006 & 0.83235 & 0.00001 & 2.06848 & 0.00003 \\
\hline 0.0007 & 15.6841 & 0.0006 & 38.937 & 0.002 & 0.0532 & 0.0007 & 0.83429 & 0.00001 & 2.07121 & 0.00003 \\
\hline 0.0007 & 15.6853 & 0.0007 & 38.932 & 0.002 & 0.0532 & 0.0007 & 0.83428 & 0.00001 & 2.07072 & 0.00003 \\
\hline 0.0007 & 15.6870 & 0.0006 & 38.984 & 0.002 & 0.0531 & 0.0007 & 0.83233 & 0.00001 & 2.06848 & 0.00003 \\
\hline 0.0006 & 15.6838 & 0.0006 & 38.929 & 0.002 & 0.0532 & 0.0006 & 0.83467 & 0.00001 & 2.07173 & 0.00005 \\
\hline 0.0009 & 15.6845 & 0.0008 & 38.923 & 0.002 & 0.0532 & 0.0009 & 0.83506 & 0.00001 & 2.07235 & 0.00004 \\
\hline 0.0010 & 15.6848 & 0.0011 & 38.869 & 0.003 & 0.0535 & 0.0010 & 0.83919 & 0.00002 & 2.07958 & 0.00008 \\
\hline 0.0005 & 15.6802 & 0.0005 & 38.858 & 0.001 & 0.0535 & 0.0005 & 0.83902 & 0.00001 & 2.07923 & 0.00004 \\
\hline 0.0008 & 15.6836 & 0.0007 & 38.871 & 0.002 & 0.0535 & 0.0008 & 0.83905 & 0.00001 & 2.07953 & 0.00003 \\
\hline 0.0007 & 15.6608 & 0.0006 & 38.854 & 0.001 & 0.0532 & 0.0007 & 0.83341 & 0.00001 & 2.06767 & 0.00003 \\
\hline 0.0006 & 15.6698 & 0.0006 & 38.932 & 0.002 & 0.0531 & 0.0006 & 0.83239 & 0.00001 & 2.06807 & 0.00003 \\
\hline 0.0006 & 15.6686 & 0.0006 & 38.923 & 0.002 & 0.0531 & 0.0006 & 0.83228 & 0.00001 & 2.06751 & 0.00004 \\
\hline 0.0005 & 15.6612 & 0.0005 & 38.905 & 0.001 & 0.0532 & 0.0005 & 0.83272 & 0.00001 & 2.06858 & 0.00004 \\
\hline 0.0010 & 15.6665 & 0.0008 & 38.923 & 0.002 & 0.0532 & 0.0010 & 0.83274 & 0.00001 & 2.06894 & 0.00003 \\
\hline 0.0008 & 15.6677 & 0.0007 & 38.926 & 0.002 & 0.0531 & 0.0008 & 0.83241 & 0.00001 & 2.06809 & 0.00004 \\
\hline 0.0006 & 15.6808 & 0.0005 & 38.970 & 0.001 & 0.0530 & 0.0006 & 0.83130 & 0.00001 & 2.06599 & 0.00004 \\
\hline 0.0006 & 15.6443 & 0.0006 & 38.428 & 0.001 & 0.0546 & 0.0006 & 0.85350 & 0.00001 & 2.09648 & 0.00002 \\
\hline 0.0006 & 15.6713 & 0.0004 & 38.827 & 0.001 & 0.0534 & 0.0006 & 0.83708 & 0.00001 & 2.07393 & 0.00003 \\
\hline 0.0006 & 15.6721 & 0.0006 & 38.827 & 0.002 & 0.0534 & 0.0006 & 0.83696 & 0.00001 & 2.07351 & 0.00003 \\
\hline 0.0007 & 15.6725 & 0.0005 & 38.837 & 0.002 & 0.0534 & 0.0007 & 0.83677 & 0.00001 & 2.07351 & 0.00002 \\
\hline 0.0008 & 15.6710 & 0.0008 & 38.832 & 0.002 & 0.0534 & 0.0008 & 0.83675 & 0.00001 & 2.07342 & 0.00005 \\
\hline 0.0005 & 15.6827 & 0.0005 & 38.841 & 0.001 & 0.0534 & 0.0005 & 0.83723 & 0.00001 & 2.07349 & 0.00002 \\
\hline 0.0008 & 15.6805 & 0.0007 & 38.819 & 0.002 & 0.0535 & 0.0008 & 0.83846 & 0.00001 & 2.07571 & 0.00003 \\
\hline 0.0006 & 15.6827 & 0.0006 & 38.826 & 0.002 & 0.0535 & 0.0006 & 0.83845 & 0.00001 & 2.07575 & 0.00003 \\
\hline 0.0005 & 15.6841 & 0.0007 & 38.862 & 0.002 & 0.0535 & 0.0005 & 0.83839 & 0.00001 & 2.07733 & 0.00002 \\
\hline 0.0010 & 15.6835 & 0.0010 & 38.823 & 0.003 & 0.0535 & 0.0010 & 0.83864 & 0.00001 & 2.07599 & 0.00006 \\
\hline 0.0008 & 15.6798 & 0.0009 & 38.812 & 0.002 & 0.0535 & 0.0008 & 0.83861 & 0.00001 & 2.07580 & 0.00005 \\
\hline 0.0007 & 15.6819 & 0.0009 & 38.828 & 0.002 & 0.0535 & 0.0007 & 0.83855 & 0.00001 & 2.07623 & 0.00005 \\
\hline 0.0007 & 15.6820 & 0.0006 & 38.826 & 0.002 & 0.0535 & 0.0007 & 0.83884 & 0.00001 & 2.07685 & 0.00004 \\
\hline 0.0006 & 15.6844 & 0.0005 & 38.917 & 0.001 & 0.0532 & 0.0006 & 0.83462 & 0.00001 & 2.07091 & 0.00002 \\
\hline 0.0007 & 15.6836 & 0.0006 & 38.914 & 0.002 & 0.0532 & 0.0007 & 0.83464 & 0.00001 & 2.07092 & 0.00003 \\
\hline 0.0006 & 15.6835 & 0.0005 & 38.831 & 0.002 & 0.0535 & 0.0006 & 0.83846 & 0.00001 & 2.07595 & 0.00004 \\
\hline 0.0009 & 15.6772 & 0.0008 & 38.807 & 0.002 & 0.0535 & 0.0009 & 0.83862 & 0.00001 & 2.07596 & 0.00004 \\
\hline 0.0006 & 15.6914 & 0.0005 & 38.937 & 0.002 & 0.0535 & 0.0006 & 0.83882 & 0.00001 & 2.08151 & 0.00004 \\
\hline 0.0009 & 15.6817 & 0.0007 & 38.841 & 0.002 & 0.0533 & 0.0009 & 0.83589 & 0.00001 & 2.07039 & 0.00006 \\
\hline 0.0006 & 15.6874 & 0.0004 & 38.869 & 0.001 & 0.0533 & 0.0006 & 0.83590 & 0.00001 & 2.07120 & 0.00003 \\
\hline 0.0007 & 15.6882 & 0.0007 & 38.870 & 0.002 & 0.0533 & 0.0007 & 0.83593 & 0.00001 & 2.07116 & 0.00004 \\
\hline 0.0008 & 15.6887 & 0.0007 & 38.872 & 0.002 & 0.0533 & 0.0008 & 0.83593 & 0.00001 & 2.07118 & 0.00004 \\
\hline 0.0006 & 15.6838 & 0.0005 & 38.856 & 0.001 & 0.0533 & 0.0006 & 0.83617 & 0.00001 & 2.07162 & 0.00002 \\
\hline 0.0008 & 15.6904 & 0.0007 & 38.881 & 0.002 & 0.0533 & 0.0008 & 0.83617 & 0.00001 & 2.07208 & 0.00002 \\
\hline 0.0007 & 15.6868 & 0.0006 & 38.870 & 0.002 & 0.0533 & 0.0007 & 0.83633 & 0.00001 & 2.07230 & 0.00002 \\
\hline 0.0007 & 15.6863 & 0.0006 & 38.867 & 0.001 & 0.0533 & 0.0007 & 0.83593 & 0.00001 & 2.07120 & 0.00002 \\
\hline 0.0008 & 15.6893 & 0.0010 & 38.883 & 0.003 & 0.0533 & 0.0008 & 0.83631 & 0.00001 & 2.07271 & 0.00005 \\
\hline 0.0008 & 15.6669 & 0.0007 & 38.815 & 0.002 & 0.0537 & 0.0008 & 0.84082 & 0.00001 & 2.08312 & 0.00003 \\
\hline 0.0008 & 15.6749 & 0.0007 & 38.949 & 0.002 & 0.0534 & 0.0008 & 0.83760 & 0.00001 & 2.08125 & 0.00003 \\
\hline 0.0006 & 15.6747 & 0.0005 & 38.935 & 0.001 & 0.0534 & 0.0006 & 0.83757 & 0.00001 & 2.08045 & 0.00004 \\
\hline 0.0006 & 15.6727 & 0.0006 & 38.886 & 0.002 & 0.0534 & 0.0006 & 0.83731 & 0.00001 & 2.07754 & 0.00006 \\
\hline 0.0006 & 15.6696 & 0.0006 & 38.881 & 0.002 & 0.0534 & 0.0006 & 0.83726 & 0.00001 & 2.07747 & 0.00003 \\
\hline 0.0009 & 15.6691 & 0.0008 & 38.878 & 0.002 & 0.0534 & 0.0009 & 0.83716 & 0.00001 & 2.07718 & 0.00004 \\
\hline 0.0007 & 15.6695 & 0.0005 & 38.880 & 0.001 & 0.0534 & 0.0007 & 0.83728 & 0.00001 & 2.07752 & 0.00003 \\
\hline 0.0007 & 15.6715 & 0.0006 & 38.849 & 0.002 & 0.0533 & 0.0007 & 0.83559 & 0.00001 & 2.07139 & 0.00003 \\
\hline 0.0006 & 15.7137 & 0.0005 & 39.086 & 0.001 & 0.0532 & 0.0006 & 0.83521 & 0.00001 & 2.07747 & 0.00003 \\
\hline 0.0006 & 15.6644 & 0.0005 & 38.819 & 0.001 & 0.0534 & 0.0006 & 0.83574 & 0.00001 & 2.07109 & 0.00003 \\
\hline 0.0011 & 15.6730 & 0.0010 & 38.845 & 0.003 & 0.0533 & 0.0011 & 0.83575 & 0.00002 & 2.07141 & 0.0000 \\
\hline 0.0013 & 15.6687 & 0.0013 & 38.835 & 0.004 & 0.0533 & 0.0013 & 0.83575 & 0.00002 & 2.07139 & 0.00008 \\
\hline
\end{tabular}

37 58' 58.3285" N $\quad 23^{\circ} 50^{\prime} 27.7016 " \mathrm{E}$

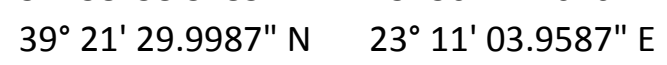
$39^{\circ} 21^{\prime} 29.9987^{\prime \prime} \mathrm{N} \quad 23^{\circ} 11^{\prime} 03.9587^{\prime \prime} \mathrm{E}$ $39^{\circ} 23^{\prime} 53.2373^{\prime \prime} \mathrm{N} \quad 23^{\circ} 10^{\prime} 13.2839^{\prime \prime} \mathrm{E}$ $39^{\circ} 23^{\prime} 53.2373^{\prime \prime} \mathrm{N} \quad 23^{\circ} 10^{\prime} 13.2839^{\prime \prime} \mathrm{E}$ $39^{\circ} 23^{\prime} 53.2373^{\prime \prime} \mathrm{N} \quad 23^{\circ} 10^{\prime} 13.2839^{\prime \prime} \mathrm{E}$ $39^{\circ} 22^{\prime} 38.7120^{\prime \prime} \mathrm{N} \quad 26^{\circ} 15^{\prime} 04.8636^{\prime \prime} \mathrm{E}$ $40^{\circ} 23^{\prime} 46.0527^{\prime \prime} \mathrm{N} \quad 25^{\circ} 33^{\prime} 38.9740^{\prime \prime} \mathrm{E}$ $40^{\circ} 31^{\prime} 01.2847^{\prime \prime} \mathrm{N} \quad 23^{\circ} 42^{\prime} 29.5980^{\prime \prime} \mathrm{E}$ $40^{\circ} 31^{\prime} 01.2847^{\prime \prime} \mathrm{N} \quad 23^{\circ} 42^{\prime} 29.5980^{\prime \prime} \mathrm{E}$ $40^{\circ} 31^{\prime} 01.2847^{\prime \prime} \mathrm{N} \quad 23^{\circ} 42^{\prime} 29.5980^{\prime \prime} \mathrm{E}$ $40^{\circ} 35^{\prime} 11.0020^{\prime \prime} \mathrm{N} \quad 23^{\circ} 45^{\prime} 00.6924^{\prime \prime} \mathrm{E}$ $40^{\circ} 35^{\prime} 11.0020^{\prime \prime} \mathrm{N} \quad 23^{\circ} 45^{\prime} 00.6924^{\prime \prime} \mathrm{E}$ $40^{\circ} 35^{\prime} 51.5256 " \mathrm{~N} \quad 23^{\circ} 44^{\prime} 50.0640^{\prime \prime} \mathrm{E}$ $40^{\circ} 35^{\prime} 51.5256^{\prime \prime} \mathrm{N} \quad 23^{\circ} 44^{\prime} 50.0640^{\prime \prime} \mathrm{E}$ $40^{\circ} 31^{\prime} 46.8264^{\prime \prime} \mathrm{N} \quad 23^{\circ} 46^{\prime} 10.0920^{\prime \prime} \mathrm{E}$ $40^{\circ} 31^{\prime} 46.8264^{\prime \prime} \mathrm{N} \quad 23^{\circ} 46^{\prime} 10.0920^{\prime \prime} \mathrm{E}$ $40^{\circ} 31^{\prime} 46.8264^{\prime \prime} \mathrm{N} \quad 23^{\circ} 46^{\prime} 10.0920^{\prime \prime} \mathrm{E}$ $40^{\circ} 46^{\prime} 32.4552^{\prime \prime} \mathrm{N} \quad 24^{\circ} 43^{\prime} 04.8144^{\prime \prime} \mathrm{E}$ $40^{\circ} 47^{\prime} 02.0371 " \mathrm{~N} \quad 24^{\circ} 37^{\prime} 19.6057^{\prime \prime} \mathrm{E}$ $40^{\circ} 43^{\prime} 16.8707^{\prime \prime} \mathrm{N} \quad 24^{\circ} 34^{\prime} 17.5007^{\prime \prime} \mathrm{E}$ $40^{\circ} 39^{\prime} 54.1540^{\prime \prime} \mathrm{N} \quad 24^{\circ} 34^{\prime} 09.6350^{\prime \prime} \mathrm{E}$ $40^{\circ} 47^{\prime} 02.0371 " \mathrm{~N} \quad 24^{\circ} 37^{\prime} 19.6057^{\prime \prime} \mathrm{E}$ $40^{\circ} 38^{\prime} 05.3052^{\prime \prime} \mathrm{N} \quad 24^{\circ} 35^{\prime} 40.6320^{\prime \prime} \mathrm{E}$ $40^{\circ} 38^{\prime} 05.3052^{\prime \prime} \mathrm{N} \quad 24^{\circ} 35^{\prime} 40.6320^{\prime \prime} \mathrm{E}$ $40^{\circ} 46^{\prime} 32.4552^{\prime \prime} \mathrm{N} \quad 24^{\circ} 43^{\prime} 04.8144^{\prime \prime} \mathrm{E}$ $40^{\circ} 46^{\prime} 32.4552^{\prime \prime} \mathrm{N} \quad 24^{\circ} 43^{\prime} 04.8144^{\prime \prime} \mathrm{E}$ $40^{\circ} 46^{\prime} 32.4552^{\prime \prime} \mathrm{N} \quad 24^{\circ} 43^{\prime} 04.8144^{\prime \prime} \mathrm{E}$ $41^{\circ} 09^{\prime} 34.8722^{\prime \prime} \mathrm{N} \quad 23^{\circ} 10^{\prime} 07.6496 " \mathrm{E}$ $41^{\circ} 08^{\prime} 14.1108^{\prime \prime} \mathrm{N} \quad 23^{\circ} 04^{\prime} 10.9271 " \mathrm{E}$ $41^{\circ} 08^{\prime} 14.1108^{\prime \prime N} \mathrm{~N} \quad 23^{\circ} 04^{\prime} 10.9271^{\prime \prime} \mathrm{E}$ $41^{\circ} 09^{\prime} 02.6280^{\prime \prime} \mathrm{N} \quad 23^{\circ} 06^{\prime} 59.0255^{\prime \prime} \mathrm{E}$ $41^{\circ} 09^{\prime} 02.6280^{\prime \prime} \mathrm{N} \quad 23^{\circ} 06^{\prime} 59.0255^{\prime \prime} \mathrm{E}$ $41^{\circ} 09^{\prime} 02.6280^{\prime \prime} \mathrm{N} \quad 23^{\circ} 06^{\prime} 59.0255^{\prime \prime} \mathrm{E}$ $41^{\circ} 08^{\prime} 47.1732^{\prime \prime} \mathrm{N} \quad 22^{\circ} 58^{\prime} 06.3695^{\prime \prime} \mathrm{E}$ $41^{\circ} 12^{\prime} 21.0816^{\prime \prime N} \quad 22^{\circ} 49^{\prime} 59.8978 " \mathrm{E}$ $41^{\circ} 22^{\prime} 27.0300^{\prime \prime} \mathrm{N} \quad 23^{\circ} 29^{\prime} 16.1016^{\prime \prime} \mathrm{E}$ $41^{\circ} 22^{\prime} 27.0300^{\prime \prime} \mathrm{N} \quad 23^{\circ} 29^{\prime} 16.1016^{\prime \prime} \mathrm{E}$ $41^{\circ} 22^{\prime} 27.0300^{\prime \prime N} \quad 23^{\circ} 29^{\prime} 16.1016^{\prime \prime} \mathrm{E}$ $41^{\circ} 22^{\prime} 27.0300^{\prime \prime N} \quad 23^{\circ} 29^{\prime} 16.1016^{\prime \prime} \mathrm{E}$ $40^{\circ} 55^{\prime} 34.9248^{\prime \prime} \mathrm{N} \quad 24^{\circ} 07^{\prime} 15.4128^{\prime \prime} \mathrm{E}$ $40^{\circ} 54^{\prime} 56.0765^{\prime \prime} \mathrm{N} \quad 24^{\circ} 06^{\prime} 37.9461^{\prime \prime} \mathrm{E}$ $40^{\circ} 54^{\prime} 56.0765^{\prime \prime} \mathrm{N} \quad 24^{\circ} 06^{\prime} 37.9461 " \mathrm{E}$ $40^{\circ} 55^{\prime} 12.7038^{\prime \prime} \mathrm{N} \quad 24^{\circ} 12^{\prime} 43.2706^{\prime \prime} \mathrm{E}$ $40^{\circ} 54^{\prime} 56.0765^{\prime \prime} \mathrm{N} \quad 24^{\circ} 06^{\prime} 37.9461 " \mathrm{E}$ $40^{\circ} 54^{\prime} 56.0765^{\prime \prime} \mathrm{N} \quad 24^{\circ} 06^{\prime} 37.9461^{\prime \prime} \mathrm{E}$ $40^{\circ} 54^{\prime} 30.6504^{\prime \prime} \mathrm{N} \quad 24^{\circ} 06^{\prime} 26.9100 " \mathrm{E}$ $40^{\circ} 54^{\prime} 30.6504^{\prime \prime N} \quad 24^{\circ} 06^{\prime} 26.9100^{\prime \prime} \mathrm{E}$ $40^{\circ} 49^{\prime} 01.4746 " \mathrm{~N} \quad 23^{\circ} 54^{\prime} 29.9437^{\prime \prime} \mathrm{E}$ $40^{\circ} 49^{\prime} 01.4746 " \mathrm{~N} \quad 23^{\circ} 54^{\prime} 29.9437^{\prime \prime} \mathrm{E}$ $40^{\circ} 54^{\prime} 56.0765^{\prime \prime} \mathrm{N} \quad 24^{\circ} 06^{\prime} 37.9461^{\prime \prime} \mathrm{E}$ $40^{\circ} 54^{\prime} 56.0765^{\prime \prime N} \quad 24^{\circ} 06^{\prime} 37.9461 " \mathrm{E}$ $40^{\circ} 55^{\prime} 24.6557^{\prime \prime} \mathrm{N} \quad 24^{\circ} 18^{\prime} 58.6504^{\prime \prime} \mathrm{E}$ $41^{\circ} 01^{\prime} 06.9872^{\prime \prime} \mathrm{N} \quad 24^{\circ} 23^{\prime} 41.6675^{\prime \prime} \mathrm{E}$ $41^{\circ} 01^{\prime} 06.9872 " \mathrm{~N} \quad 24^{\circ} 23^{\prime} 41.6675^{\prime \prime} \mathrm{E}$ $41^{\circ} 01^{\prime} 06.9872^{\prime \prime} \mathrm{N} \quad 24^{\circ} 23^{\prime} 41.6675^{\prime \prime} \mathrm{E}$ $41^{\circ} 01^{\prime} 06.9872 " \mathrm{~N} \quad 24^{\circ} 23^{\prime} 41.6675^{\prime \prime} \mathrm{E}$ $41^{\circ} 01^{\prime} 14.2529^{\prime \prime} \mathrm{N} \quad 24^{\circ} 23^{\prime} 35.2166^{\prime \prime} \mathrm{E}$

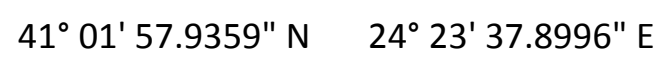
$41^{\circ} 01^{\prime} 57.9359^{\prime \prime N} \mathrm{~N} \quad 24^{\circ} 23^{\prime} 37.8996^{\prime \prime} \mathrm{E}$ $41^{\circ} 02^{\prime} 06.8675^{\prime \prime} \mathrm{N} \quad 24^{\circ} 23^{\prime} 52.8720^{\prime \prime} \mathrm{E}$ 41 $01^{\circ} 47.8883 " \mathrm{~N} \quad 24^{\circ} 24^{\prime} 19.5587^{\prime \prime} \mathrm{E}$ $41^{\circ} 22^{\prime} 44.8599^{\prime \prime} \mathrm{N} \quad 24^{\circ} 56^{\prime} 00.5299^{\prime \prime} \mathrm{E}$ $41^{\circ} 22^{\prime} 44.8599^{\prime \prime N} \quad 24^{\circ} 56^{\prime} 00.5299^{\prime \prime} \mathrm{E}$ $41^{\circ} 20^{\prime} 56.9417^{\prime \prime} \mathrm{N} \quad 25^{\circ} 00^{\prime} 09.1599^{\prime \prime} \mathrm{E}$ $41^{\circ} 01^{\prime} 16.1292^{\prime \prime} \mathrm{N} \quad 25^{\circ} 49^{\prime} 03.5579^{\prime \prime} \mathrm{E}$ $41^{\circ} 01^{\prime} 16.1292^{\prime \prime} \mathrm{N} \quad 25^{\circ} 49^{\prime} 03.5579 " \mathrm{E}$ $41^{\circ} 01^{\prime} 16.1292^{\prime \prime} \mathrm{N} \quad 25^{\circ} 49^{\prime} 03.5579 " \mathrm{E}$ $41^{\circ} 01^{\prime} 16.1292^{\prime \prime} \mathrm{N} \quad 25^{\circ} 49^{\prime} 03.5579^{\prime \prime} \mathrm{E}$ $41^{\circ} 00^{\prime} 39.7079 " \mathrm{~N} \quad 25^{\circ} 44^{\prime} 40.8443 " \mathrm{E}$ $41^{\circ} 00^{\prime} 46.5444^{\prime \prime} \mathrm{N} \quad 25^{\circ} 44^{\prime} 31.1711 " \mathrm{E}$

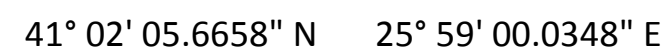
41 $03^{\circ} 26.5571 " \mathrm{~N} \quad 25^{\circ} 49^{\prime} 11.7299^{\prime \prime} \mathrm{E}$

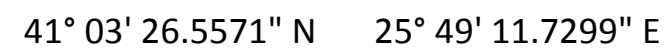


$0.83582 \quad 0.00001$ $0.83608 \quad 0.00001$
$2.071560 .00005 \quad 41^{\circ} 03^{\prime} 26.5571 " \mathrm{~N} \quad 25^{\circ} 49^{\prime} 11.7299^{\prime \prime} \mathrm{E}$ $2.073610 .00003 \quad 40^{\circ} 54^{\prime} 32.0399 " \mathrm{~N} \quad 26^{\circ} 02^{\prime} 14.8559^{\prime \prime} \mathrm{E}$ 


\begin{tabular}{|c|c|c|}
\hline Tmod & $\mu$ & k \\
\hline 43 & 9.855 & 3.858 \\
\hline 46 & 9.885 & 3.908 \\
\hline 46 & 9.885 & 3.908 \\
\hline 43 & 9.883 & 3.878 \\
\hline 36 & 9.878 & 3.865 \\
\hline 31 & 9.873 & 3.870 \\
\hline 26 & 9.846 & 3.848 \\
\hline 32 & 9.859 & 3.848 \\
\hline 54 & 9.938 & 3.893 \\
\hline 46 & 9.917 & 3.888 \\
\hline 32 & 9.875 & 3.868 \\
\hline 30 & 9.874 & 3.874 \\
\hline 35 & 9.869 & 3.853 \\
\hline 34 & 9.870 & 3.852 \\
\hline 28 & 9.849 & 3.864 \\
\hline 46 & 9.837 & 3.886 \\
\hline 34 & 9.883 & 3.884 \\
\hline 29 & 9.856 & 3.864 \\
\hline 70 & 9.886 & 3.902 \\
\hline 34 & 9.852 & 3.877 \\
\hline 28 & 9.854 & 3.863 \\
\hline 57 & 9.906 & 3.885 \\
\hline 54 & 9.889 & 3.887 \\
\hline 23 & 9.846 & 3.848 \\
\hline 23 & 9.865 & 3.854 \\
\hline 37 & 9.884 & 3.891 \\
\hline 181 & 9.933 & 4.005 \\
\hline 172 & 9.924 & 4.002 \\
\hline 176 & 9.943 & 4.005 \\
\hline 186 & 9.946 & 4.009 \\
\hline 184 & 9.940 & 4.008 \\
\hline 144 & 9.912 & 3.996 \\
\hline 189 & 9.929 & 3.892 \\
\hline 190 & 9.936 & 3.894 \\
\hline 141 & 9.902 & 3.994 \\
\hline 115 & 9.943 & 3.948 \\
\hline 118 & 9.925 & 3.947 \\
\hline 117 & 9.940 & 3.949 \\
\hline 176 & 9.987 & 4.004 \\
\hline 163 & 9.951 & 4.003 \\
\hline 157 & 9.948 & 3.996 \\
\hline 163 & 9.952 & 4.003 \\
\hline 159 & 9.941 & 4.001 \\
\hline 161 & 9.955 & 4.003 \\
\hline 158 & 9.938 & 3.999 \\
\hline 30 & 9.905 & 3.919 \\
\hline 32 & 9.912 & 3.921 \\
\hline 36 & 9.867 & 3.939 \\
\hline 36 & 9.868 & 3.939 \\
\hline 74 & 9.891 & 3.948 \\
\hline 79 & 9.898 & 3.950 \\
\hline 109 & 9.984 & 4.010 \\
\hline 108 & 9.954 & 3.993 \\
\hline 108 & 9.969 & 3.991 \\
\hline 109 & 9.960 & 3.997 \\
\hline 114 & 9.970 & 4.002 \\
\hline 113 & 9.988 & 4.004 \\
\hline 3 & 9.899 & 3.904 \\
\hline 15 & 9.904 & 3.913 \\
\hline 26 & 9.903 & 3.916 \\
\hline 81 & 9.922 & 3.960 \\
\hline 120 & 9.990 & 4.029 \\
\hline 123 & 10.012 & 4.047 \\
\hline 122 & 10.012 & 4.047 \\
\hline 121 & 9.988 & 4.029 \\
\hline 120 & 9.985 & 4.028 \\
\hline 40 & 9.895 & 3.936 \\
\hline 33 & 9.877 & 3.931 \\
\hline 39 & 9.895 & 3.936 \\
\hline 34 & 9.905 & 3.919 \\
\hline 345 & 9.942 & 4.010 \\
\hline 367 & 9.958 & 4.016 \\
\hline 345 & 9.944 & 4.009 \\
\hline
\end{tabular}




\begin{tabular}{|c|c|c|}
\hline 364 & 9.950 & 4.015 \\
\hline 68 & 9.941 & 3.959 \\
\hline 68 & 9.941 & 3.960 \\
\hline 68 & 9.953 & 3.965 \\
\hline 71 & 9.956 & 3.967 \\
\hline 73 & 9.950 & 3.967 \\
\hline 213 & 9.924 & 4.078 \\
\hline 360 & 9.906 & 4.009 \\
\hline 37 & 9.788 & 3.913 \\
\hline 37 & 9.797 & 3.914 \\
\hline 39 & 9.805 & 3.915 \\
\hline 70 & 9.831 & 3.921 \\
\hline 68 & 9.828 & 3.918 \\
\hline 70 & 9.841 & 3.922 \\
\hline 75 & 9.858 & 3.926 \\
\hline 45 & 9.823 & 3.922 \\
\hline 39 & 9.814 & 3.919 \\
\hline 115 & 9.826 & 3.946 \\
\hline 151 & 9.880 & 3.976 \\
\hline 45 & 9.871 & 3.938 \\
\hline 72 & 9.858 & 3.942 \\
\hline 73 & 9.863 & 3.938 \\
\hline 42 & 9.861 & 3.936 \\
\hline 78 & 9.859 & 3.943 \\
\hline 85 & 9.863 & 3.946 \\
\hline 154 & 9.883 & 3.978 \\
\hline 146 & 9.865 & 3.972 \\
\hline 150 & 9.877 & 3.977 \\
\hline 32 & 9.771 & 3.897 \\
\hline 24 & 9.799 & 3.917 \\
\hline 21 & 9.794 & 3.912 \\
\hline 20 & 9.769 & 3.912 \\
\hline 26 & 9.788 & 3.919 \\
\hline 22 & 9.791 & 3.915 \\
\hline 17 & 9.834 & 3.916 \\
\hline 343 & 9.804 & 3.973 \\
\hline 104 & 9.824 & 3.932 \\
\hline 103 & 9.826 & 3.930 \\
\hline 100 & 9.827 & 3.932 \\
\hline 99 & 9.821 & 3.930 \\
\hline 119 & 9.866 & 3.936 \\
\hline 137 & 9.863 & 3.944 \\
\hline 139 & 9.871 & 3.946 \\
\hline 140 & 9.876 & 3.963 \\
\hline 143 & 9.875 & 3.947 \\
\hline 139 & 9.862 & 3.943 \\
\hline 140 & 9.869 & 3.949 \\
\hline 145 & 9.871 & 3.952 \\
\hline 78 & 9.861 & 3.936 \\
\hline 77 & 9.858 & 3.936 \\
\hline 140 & 9.875 & 3.949 \\
\hline 136 & 9.852 & 3.942 \\
\hline 155 & 9.905 & 4.005 \\
\hline 96 & 9.856 & 3.918 \\
\hline 102 & 9.877 & 3.930 \\
\hline 103 & 9.880 & 3.930 \\
\hline 104 & 9.882 & 3.931 \\
\hline 103 & 9.866 & 3.929 \\
\hline 110 & 9.889 & 3.938 \\
\hline 108 & 9.877 & 3.936 \\
\hline 101 & 9.874 & 3.929 \\
\hline 111 & 9.886 & 3.942 \\
\hline 162 & 9.825 & 3.982 \\
\hline 117 & 9.839 & 4.000 \\
\hline 116 & 9.839 & 3.992 \\
\hline 110 & 9.830 & 3.965 \\
\hline 105 & 9.819 & 3.962 \\
\hline 103 & 9.816 & 3.960 \\
\hline 106 & 9.818 & 3.962 \\
\hline 80 & 9.818 & 3.921 \\
\hline 118 & 9.970 & 4.017 \\
\hline 75 & 9.793 & 3.911 \\
\hline 84 & 9.824 & 3.921 \\
\hline 79 & 9.809 & 3.918 \\
\hline
\end{tabular}


$\begin{array}{lll}78 & 9.802 & 3.917\end{array}$

$\begin{array}{lll}92 & 9.831 & 3.941\end{array}$ 


\begin{tabular}{|c|c|c|c|c|}
\hline Sample & District & Mine & Ancient Mining & Collected by \\
\hline 388 & Lavrion & Esperanza & Yes & \\
\hline 389 & Lavrion & Esperanza & Yes & \\
\hline 390 & Lavrion & Esperanza & Yes & \\
\hline 396 & Lavrion & Kamareza & Yes & \\
\hline 397 & Lavrion & Kamareza & Yes & \\
\hline 398 & Lavrion & Kamareza & Yes & \\
\hline 399 & Lavrion & Kamareza & Yes & \\
\hline D1 & Lavrion & Kamareza & Yes & Dayton \\
\hline TG60A-3 & Lavrion & Kamareza & Yes & NHG/Gentner/Wagner \\
\hline TG60A-2 & Lavrion & Kamareza & Yes & NHG/Gentner/Wagner \\
\hline 383 & Lavrion & Plaka & No & V. Avdis \\
\hline 384 & Lavrion & Plaka & No & V. Avdis \\
\hline $22252 / 91$ & Lavrion & Plaka & No & S. Papastavrou \\
\hline Filon 80 & Lavrion & Plaka & No & S. Papastavrou \\
\hline PL1/90 & Lavrion & Plaka & No & NHG\&ZSG \\
\hline PL2 & Lavrion & Plaka & No & NHG\&ZSG \\
\hline 385 & Lavrion & Plaka 33 & No & V. Avdis \\
\hline 386 & Lavrion & Plaka 33 & No & V. Avdis \\
\hline 387 & Lavrion & Plaka 33 & No & V. Avdis \\
\hline 391 & Lavrion & Plaka-80 & No & V. Avdis \\
\hline 392 & Lavrion & Plaka-80 & No & V. Avdis \\
\hline 393 & Lavrion & Plaka-80 & No & V. Avdis \\
\hline 394 & Lavrion & Plaka-80 & No & V. Avdis \\
\hline A6 & Lavrion & Plaka N. & No & NHG\&ZSG \\
\hline A5 & Lavrion & Plaka N. & No & NHG\&ZSG \\
\hline A5B & Lavrion & Plaka N. & No & NHG\&ZSG \\
\hline C3 & Lavrion & Plaka S. & No & NHG\&ZSG \\
\hline 395 & Lavrion & Plaka, Filon Sklives & No & V. Avdis \\
\hline B2 & Lavrion & Plaka & No & Dayton \\
\hline B5 & Lavrion & Plaka & No & Dayton \\
\hline S12 published & Lavrion & Sounio & Yes & NHG\&ZSG \\
\hline SOUL 7a & Lavrion & Soureza & Yes & NHG\&ZSG \\
\hline 22364B & Makronisos & Central mines & Yes & S. Papastavrou \\
\hline 22354 KAM 354 & Lavrion & Kamareza & Yes & S. Papastavrou \\
\hline KAM 102 & Lavrion & Kamareza & Yes & NHG\&ZSG \\
\hline 22221 MP 221 & Lavrion & Megala Pevka & Yes & S. Papastavrou \\
\hline 22235 PL 235 & Lavrion & Plaka & No & S. Papastavrou \\
\hline 22251 PL 251 & Lavrion & Plaka & No & S. Papastavrou \\
\hline 22252a PL 252A & Lavrion & Plaka & No & S. Papastavrou \\
\hline 22345 PL 345 & Lavrion & Plaka & No & S. Papastavrou \\
\hline PL 11 & Lavrion & Plaka & No & NHG\&ZSG \\
\hline PL 16 & Lavrion & Plaka Christiana & Yes & NHG\&ZSG \\
\hline PL 17 & Lavrion & Plaka Christiana & Yes & NHG\&ZSG \\
\hline PL 13 & Lavrion & Plaka-80 & No & NHG\&ZSG \\
\hline PL 14 & Lavrion & Plaka-80 & No & NHG\&ZSG \\
\hline PL 15 & Lavrion & Plaka-80 & No & NHG\&ZSG \\
\hline PL F85 & Lavrion & Plaka-80 & No & NHG\&ZSG \\
\hline KALL 1 & Euboea & Kallianou & Yes & NHG/ZSG \\
\hline KALL 2 (TG59) & Euboea & Kallianou & Yes & NHG/ZSG \\
\hline KALL3 (TG59) & Euboea & Kallianou & Yes & NHG/ZSG \\
\hline KALL3 (TG59) & Euboea & Kallianou, Saliza mine & No & NHG/ZSG \\
\hline TG-56A & Euboea & Almyropotamos & Yes & \\
\hline TG-56B & Euboea & Almyropotamos & Yes & \\
\hline AVE 1 (TG56) & Euboea & Almyropotamos & Yes & NHG/ZSG \\
\hline AVE2 (TG56) & Euboea & Almyropotamos & Yes & NHG/ZSG \\
\hline $\mathrm{TG} 43 / 9$ & Siphnos & Ay. Sostis Dump & Yes & Gale \\
\hline TG43/10 & Siphnos & Ay. Sostis & Yes & Gale \\
\hline $\mathrm{TG} 43 / 10$ & Siphnos & Ay. Sostis & Yes & Gale \\
\hline
\end{tabular}




\begin{tabular}{|c|c|c|c|c|}
\hline TG54-4/2 & Siphnos & Voreini & Yes & \\
\hline TG55A-13 & Siphnos & Kapsalos-Tsingoura & Yes & \\
\hline TG55A-14 & Siphnos & Kapsalos-Tsingoura & Yes & \\
\hline TG55A-15 & Siphnos & Kapsalos-Tsingoura & Yes & \\
\hline TG55A-16 & Siphnos & Kapsalos-Tsingoura & Yes & \\
\hline TG55A-17 & Siphnos & Kapsalos-Tsingoura & Yes & \\
\hline TG55A-18 & Siphnos & Kapsalos-Tsingoura & Yes & \\
\hline TG55A-19 & Siphnos & Kapsalos-Tsingoura & Yes & \\
\hline TG55A-20 & Siphnos & Kapsalos-Tsingoura & Yes & \\
\hline TG55A-21 & Siphnos & Kapsalos-Tsingoura & Yes & \\
\hline TG69-6 & Siphnos & Xero Xylo & Yes & \\
\hline SER21/TG52a2 & Seriphos & Moutoula & Yes & NHG \\
\hline SER1/96 & Seriphos & Moutoula & Yes & ZSG/NHG \\
\hline SER10/2 & Seriphos & Moutoula & Yes & ZSG/NHG \\
\hline SER2/2 & Seriphos & Moutoula & Yes & ZSG/NHG \\
\hline SER25/TG52b5 & Seriphos & Moutoula & Yes & Gale \\
\hline SER26/TG52b6 & Seriphos & Moutoula & Yes & Gale \\
\hline SER27/TG52b7 & Seriphos & Moutoula & Yes & Gale \\
\hline SER28/TG52 B8 & Seriphos & Moutoula & Yes & Gale \\
\hline SER29 & Seriphos & Moutoula & Yes & Gale \\
\hline SER31 & Seriphos & Moutoula & Yes & Gale \\
\hline SER33 & Seriphos & Moutoula & Yes & Gale \\
\hline SER34 & Seriphos & Moutoula & Yes & Gale \\
\hline SER35 & Seriphos & Moutoula & Yes & Gale \\
\hline SER36 & Seriphos & Moutoula & Yes & Gale \\
\hline SER37 & Seriphos & Moutoula & Yes & Gale \\
\hline SER39 & Seriphos & Moutoula & Yes & Gale \\
\hline SER40 & Seriphos & Moutoula & Yes & Gale \\
\hline SER41 & Seriphos & Moutoula & Yes & Gale \\
\hline SER42 & Seriphos & Moutoula & Yes & Gale \\
\hline SER45 & Seriphos & Moutoula & Yes & Gale \\
\hline SER7/4 & Seriphos & Moutoula & Yes & Gale \\
\hline SER8/2 & Seriphos & Moutoula & Yes & Gale \\
\hline SER9/2 & Seriphos & Moutoula & Yes & Gale \\
\hline SER 20 & Seriphos & Moutoula & Yes & ZSG/NHG \\
\hline SER14/2 & Seriphos & Moutoula & Yes & NHG \\
\hline SER18/2 & Seriphos & Moutoula & Yes & NHG \\
\hline SER20 & Seriphos & Moutoula & Yes & NHG \\
\hline TG $52 \mathrm{~A} 2$ & Seriphos & Moutoula & Yes & Gale \\
\hline TG 52 A4 & Seriphos & Moutoula & Yes & Gale \\
\hline TG 52 A5 & Seriphos & Moutoula & Yes & Gale \\
\hline SER1 & Seriphos & Moutoula & Yes & ZSG/NHG \\
\hline SER10/1 & Seriphos & Moutoula & Yes & ZSG/NHG \\
\hline SER12/1 & Seriphos & Moutoula & Yes & ZSG/NHG \\
\hline SER12/2 & Seriphos & Moutoula & Yes & ZSG/NHG \\
\hline SER13/2 & Seriphos & Moutoula & Yes & ZSG/NHG \\
\hline SER14/1 & Seriphos & Moutoula & Yes & ZSG/NHG \\
\hline SER15/1 & Seriphos & Moutoula & Yes & ZSG/NHG \\
\hline SER16/2 & Seriphos & Moutoula & Yes & ZSG/NHG \\
\hline SER17/1 & Seriphos & Moutoula & Yes & ZSG/NHG \\
\hline SER17/2 & Seriphos & Moutoula & Yes & ZSG/NHG \\
\hline SER18/1 & Seriphos & Moutoula & Yes & ZSG/NHG \\
\hline SER19 & Seriphos & Moutoula & Yes & ZSG/NHG \\
\hline SER2/95 (TG52A) & Seriphos & Moutoula & Yes & Gale \\
\hline SER3 (TG52B) & Seriphos & Moutoula & Yes & Gale \\
\hline SER15/2 & Seriphos & Moutoula & Yes & Gale \\
\hline SER23/TG52b3 & Seriphos & Moutoula & Yes & Gale \\
\hline
\end{tabular}




\begin{tabular}{|c|c|c|c|c|}
\hline SER5/2 & Seriphos & Moutoula & Yes & Gale \\
\hline SER6/1 & Seriphos & Moutoula & Yes & Gale \\
\hline SER6/2 & Seriphos & Moutoula & Yes & Gale \\
\hline SER7/1 & Seriphos & Moutoula & Yes & Gale \\
\hline SER8/1 & Seriphos & Moutoula & Yes & Gale \\
\hline SER9/1 & Seriphos & Moutoula & Yes & Gale \\
\hline TG 52 B1 & Seriphos & Moutoula & Yes & Gale \\
\hline TG 52 B2/1 & Seriphos & Moutoula & Yes & Gale \\
\hline TG 52 B2/2 & Seriphos & Moutoula & Yes & Gale \\
\hline TG 52 B3 & Seriphos & Moutoula & Yes & Gale \\
\hline TG 52 B6 & Seriphos & Moutoula & Yes & Gale \\
\hline TG 52 B7 & Seriphos & Moutoula & Yes & Gale \\
\hline MIL1 & Milos & Pilonisi & & IGME \\
\hline IGMRII & Milos & & & \\
\hline SYR 17A-1 & Syros & Komito & No & ZSG/NHG \\
\hline SYR 17A-2 & Syros & Komito & No & ZSG/NHG \\
\hline SYR $18 A-1$ & Syros & Komito & No & ZSG/NHG \\
\hline SYR $18 \mathrm{~A}-2$ & Syros & Komito & No & ZSG/NHG \\
\hline SYR 3A-1 & Syros & Rozos & Yes & ZSG/NHG \\
\hline SYR 3A-2 & Syros & Rozos & Yes & ZSG/NHG \\
\hline SYR $3 A-3$ & Syros & Rozos & Yes & ZSG/NHG \\
\hline SYR $3 A-4$ & Syros & Rozos & Yes & ZSG/NHG \\
\hline SYR 3B & Syros & Rozos & Yes & ZSG/NHG \\
\hline SYR 3C-2 & Syros & Rozos & Yes & ZSG/NHG \\
\hline SYR 3C-3 & Syros & Rozos & Yes & ZSG/NHG \\
\hline SYR 2B & Syros & Rozos & Yes & ZSG/NHG \\
\hline SYR $2 C$ & Syros & Rozos & Yes & ZSG/NHG \\
\hline SYR 2D-1 & Syros & Rozos & Yes & ZSG/NHG \\
\hline SYR 2D-2 & Syros & Rozos & Yes & ZSG/NHG \\
\hline SYR 2D-3 & Syros & Rozos & Yes & ZSG/NHG \\
\hline JK 5 & Kythnos & Agios Dimitrios & Yes & Jansen, Utrecht \\
\hline JK 4 & Kythnos & Agios Dimitrios & Yes & Jansen, Utrecht \\
\hline KYTG9 & Kythnos & Agios Dimitrios & Yes & Jansen, Utrecht \\
\hline KYTG10 & Kythnos & Agios Dimitrios & Yes & Jansen, Utrecht \\
\hline ANTI 5 & Antiparos & Agios Georgios & No & Gale \\
\hline ANTI 6 & Antiparos & Agios Georgios & No & Gale \\
\hline ANTI 7 & Antiparos & Agios Georgios & No & Gale \\
\hline ANTI 8 & Antiparos & Agios Georgios & No & Gale \\
\hline ANTI 9 & Antiparos & Agios Georgios & No & Gale \\
\hline ANTI 10 & Antiparos & Agios Georgios & No & Gale \\
\hline ANTI 11 & Antiparos & Agios Georgios & No & Gale \\
\hline ANTI 12 & Antiparos & Agios Georgios & No & Gale \\
\hline ANTI 13 & Antiparos & Agios Georgios & No & Gale \\
\hline ANTI 14 & Antiparos & Agios Georgios & No & Gale \\
\hline AP1/95 & Antiparos & Agios Georgios & No & Gale \\
\hline AP4/95 & Antiparos & Agios Georgios & No & Gale \\
\hline AP8 & Antiparos & Agios Georgios & No & Gale \\
\hline AP9 & Antiparos & Agios Georgios & No & Gale \\
\hline TG45D & Polyaigos & Tris Panagies & No & Gale/Gentner \\
\hline TG45E & Polyaigos & Tris Panagies & No & Gale/Gentner \\
\hline SN 12 B & Thera & Athinios & No & Gale/Bassiakos \\
\hline SN $12 \mathrm{C} / 1$ & Thera & Athinios & No & Gale/Bassiakos \\
\hline SN 17 B & Thera & Athinios & No & Gale/Bassiakos \\
\hline SN $20 \mathrm{~A}$ & Thera & Athinios & No & Gale/Bassiakos \\
\hline SN $20 \mathrm{~B}$ & Thera & Athinios & No & Gale/Bassiakos \\
\hline SN $21 \mathrm{~A}$ & Thera & Athinios & No & Gale/Bassiakos \\
\hline SN $21 \mathrm{C}$ & Thera & Athinios & No & Gale/Bassiakos \\
\hline SN $21 \mathrm{D}$ & Thera & Athinios & No & Gale/Bassiakos \\
\hline SN $21 \mathrm{E}$ & Thera & Athinios & No & Gale/Bassiakos \\
\hline
\end{tabular}




\begin{tabular}{|c|c|c|c|c|}
\hline $360 \mathrm{~B} / 2$ & Thera & Cape Athinios & No & Karlsruhe \\
\hline $\mathrm{PH} 30 \mathrm{o} / 2$ & Thera & Cape Athinios & No & Karlsruhe \\
\hline ANAPHI1 & Anaphi & Doumbaria & No & NHG\&ZSG \\
\hline ANA1/95 & Anaphi & Stavros & No & NHG\&ZSG \\
\hline ANA11a & Anaphi & Stavros & No & NHG\&ZSG \\
\hline ANA11b & Anaphi & Stavros & No & NHG\&ZSG \\
\hline ANA13 & Anaphi & Stavros & No & NHG\&ZSG \\
\hline ANA14 & Anaphi & Stavros & No & NHG\&ZSG \\
\hline ANA15 & Anaphi & Stavros & No & NHG\&ZSG \\
\hline ANA16 & Anaphi & Stavros & No & NHG\&ZSG \\
\hline ANA17 & Anaphi & Stavros & No & NHG\&ZSG \\
\hline ANA18 & Anaphi & Stavros & No & NHG\&ZSG \\
\hline ANA4 & Anaphi & Stavros & No & NHG\&ZSG \\
\hline ANA5 & Anaphi & Stavros & No & NHG\&ZSG \\
\hline ANA6 & Anaphi & Stavros & No & NHG\&ZSG \\
\hline ANA7 & Anaphi & Stavros & No & NHG\&ZSG \\
\hline TG49 & Samos & Ampelos (Nenedes) & No & Gentner \\
\hline TG50B & Samos & Dhrakaioi, W. shore,Kalives & No & Gentner \\
\hline TG50A & Samos & Dhrakaioi, W. shore, Mili & No & Gentner \\
\hline TG47 published & Samos & Sikia, south shore & No & Gentner \\
\hline TG46 & Samos & Spatharaioi, galleries & No & Gentner \\
\hline TG48 & Samos & Zestos, N. Shore & No & Gentner \\
\hline 27711 & Tinos & Apigania & No & Papastavrou \\
\hline 27798 & Tinos & Apigania & No & Papastavrou \\
\hline $27708 / 2$ & Tinos & Apigania & No & Papastavrou \\
\hline Ti1 & Tinos & Apigania & No & Papastavrou \\
\hline $\mathrm{Ti} 2$ & Tinos & Apigania & No & Papastavrou \\
\hline Ti27711 & Tinos & Apigania & No & Papastavrou \\
\hline Ti3 & Tinos & Apigania & No & Papastavrou \\
\hline Kea MEN 1 & Kea & Schoinos & No & Mendoni \\
\hline Kea MEN 4 & Kea & Schoinos & No & Mendoni \\
\hline $\mathrm{F} 1 \mathrm{~W} / 1$ & Kea & Faros & No & ZSG/NHG \\
\hline F 1X/1 (TG 123B) & Kea & Faros & No & ZSG/NHG \\
\hline F $1 X / 2$ (TG 123B) & Kea & Faros & No & ZSG/NHG \\
\hline FAR $1 / 3$ & Kea & Faros & No & ZSG/NHG \\
\hline FAR $2 / 1$ & Kea & Faros & No & ZSG/NHG \\
\hline FAR 5/1 & Kea & Faros & No & ZSG/NHG \\
\hline PET5 & Kea & Faros & No & ZSG/NHG \\
\hline PET6 & Kea & Faros & No & ZSG/NHG \\
\hline PET7 & Kea & Faros & No & ZSG/NHG \\
\hline KGP1 & Kea & Faros & No & Jack Davis \\
\hline KGP1 & Kea & Faros & No & Jack Davis \\
\hline KJD1A & Kea & Faros & No & Jack Davis \\
\hline KJD1B & Kea & Faros & No & Jack Davis \\
\hline KJD1C & Kea & Faros & No & Jack Davis \\
\hline $\mathrm{N} 1 \mathrm{~W} / 1$ & Kea & Nikoleri & No & ZSG/NHG \\
\hline $\mathrm{N} 1 \mathrm{~W} / 2$ & Kea & Nikoleri & No & ZSG/NHG \\
\hline $\mathrm{N} 2 \mathrm{C}$ & Kea & Nikoleri & No & ZSG/NHG \\
\hline $\mathrm{N} 2 \mathrm{~W}$ & Kea & Nikoleri & No & ZSG/NHG \\
\hline $\mathrm{N} 2 \mathrm{~W}$ & Kea & Nikoleri & No & ZSG/NHG \\
\hline $\mathrm{NIX}$ & Kea & Nikoleri & No & ZSG/NHG \\
\hline NIK $1 C$ & Kea & Nikoleri & No & ZSG/NHG \\
\hline PET10 & Kea & Petroussa & No & ZSG/NHG \\
\hline PET11 & Kea & Petroussa & No & ZSG/NHG \\
\hline PET12 & Kea & Petroussa & No & ZSG/NHG \\
\hline PET16 & Kea & Petroussa & No & ZSG/NHG \\
\hline PET19 & Kea & Petroussa & No & ZSG/NHG \\
\hline PET20 & Kea & Petroussa & No & ZSG/NHG \\
\hline PW 1 & Kea & Petroussa & No & ZSG/NHG \\
\hline
\end{tabular}




\begin{tabular}{|c|c|c|c|c|}
\hline PY 1 & Kea & Petroussa & No & ZSG/NHG \\
\hline PY 2 & Kea & Petroussa & No & ZSG/NHG \\
\hline D6a & Kea & Schoinos & No & Mendoni \\
\hline G3 & Kea & Schoinos & No & Mendoni \\
\hline Kea MEN 2 & Kea & Schoinos & No & Mendoni \\
\hline Kea MEN 3 & Kea & Schoinos & No & Mendoni \\
\hline KG2 & Kea & Spasmata & No & Photos \\
\hline AT-1d & SW Peloponnisos & Ano Tiros & No & NHG/ZSG \\
\hline AT-1e & SW Peloponnisos & Ano Tiros & No & NHG/ZSG \\
\hline AT-1f & SW Peloponnisos & Ano Tiros & No & NHG/ZSG \\
\hline AT-1j & SW Peloponnisos & Ano Tiros & No & NHG/ZSG \\
\hline AT-1m & SW Peloponnisos & Ano Tiros & No & NHG/ZSG \\
\hline 4541 & SW Peloponnisos & Molai & No & IGME \\
\hline 4550 & SW Peloponnisos & Molai & No & IGME \\
\hline $4543 / 94$ & SW Peloponnisos & Molai & No & IGME \\
\hline MOL 11c & SW Peloponnisos & Molai & No & NHG/ZSG \\
\hline MOL 11d & SW Peloponnisos & Molai & No & NHG/ZSG \\
\hline MOL $11 f$ & SW Peloponnisos & Molai & No & NHG/ZSG \\
\hline MOL $11 f$ & SW Peloponnisos & Molai & No & NHG/ZSG \\
\hline 4546 & SW Peloponnisos & Molai & No & IGME \\
\hline MOL 11b & SW Peloponnisos & Molai & No & NHG/ZSG \\
\hline $\mathrm{CH} 12$ & Chios & & No & Papastavrou \\
\hline $\mathrm{CHI}$ & Chios & Agrelopos & No & Papastavrou \\
\hline $\mathrm{CHI} 3$ & Chios & Rosoja & No & Papastavrou \\
\hline PIN 1A & Pelion & Agios Konstantinos & Yes & NHG/ZSG \\
\hline PIN 5A & Pelion & Agios Konstantinos & Yes & NHG/ZSG \\
\hline PIN 5A4 & Pelion & Agios Konstantinos & Yes & NHG/ZSG \\
\hline PIN 5A6 & Pelion & Agios Konstantinos & Yes & NHG/ZSG \\
\hline PIN 3A1 & Pelion & Agios Konstantinos & Yes & NHG/ZSG \\
\hline PIN $3 A 2$ & Pelion & Agios Konstantinos & Yes & NHG/ZSG \\
\hline PIN 2A & Pelion & Agios Konstantinos & Yes & NHG/ZSG \\
\hline PIN 5A2 & Pelion & Agios Konstantinos & Yes & NHG/ZSG \\
\hline PVORE-3 & Pelion & Ksourichti & Yes & Vaxevanopoulos \\
\hline TG51 & Lesbos & Argenos & Yes & Gentner \\
\hline ML-A & Chalkidiki & Madem Lakkos & Yes & \\
\hline ML-A & Chalkidiki & Madem Lakkos & Yes & \\
\hline ML-A & Chalkidiki & Madem Lakkos & Yes & \\
\hline ML-A & Chalkidiki & Madem Lakkos & Yes & \\
\hline ML-B & Chalkidiki & Madem Lakkos & Yes & \\
\hline ML-B & Chalkidiki & Madem Lakkos & Yes & \\
\hline ML-B & Chalkidiki & Madem Lakkos & Yes & \\
\hline ML-B & Chalkidiki & Madem Lakkos & Yes & \\
\hline ML-Nr.3 & Chalkidiki & Madem Lakkos & Yes & \\
\hline ML-Nr.5a & Chalkidiki & Madem Lakkos & Yes & \\
\hline ML-Nr.5b & Chalkidiki & Madem Lakkos & Yes & \\
\hline ML-Nr.5 & Chalkidiki & Madem Lakkos & Yes & \\
\hline B-97 & Chalkidiki & Madem Lakkos & Yes & \\
\hline E-5 & Chalkidiki & Madem Lakkos & Yes & \\
\hline$E-27$ & Chalkidiki & Madem Lakkos & Yes & \\
\hline$E-28$ & Chalkidiki & Madem Lakkos & Yes & \\
\hline$E-37$ & Chalkidiki & Madem Lakkos & Yes & \\
\hline$E-40$ & Chalkidiki & Madem Lakkos & Yes & \\
\hline $7 \sim 1 \sim 5$ & Chalkidiki & Madem Lakkos & Yes & \\
\hline 8 2 1 & Chalkidiki & Madem Lakkos & Yes & \\
\hline 7 10 1 & Chalkidiki & Madem Lakkos & Yes & \\
\hline 7 29 1 & Chalkidiki & Madem Lakkos & Yes & \\
\hline AVE1 & Chalkidiki & Madem Lakkos & Yes & \\
\hline GRL1 & Chalkidiki & Madem Lakkos & Yes & \\
\hline GRL3 & Chalkidiki & Madem Lakkos & Yes & \\
\hline
\end{tabular}




\begin{tabular}{|c|c|c|c|c|}
\hline $38 \mathrm{~A}-8$ & Chalkidiki & Mavres Petres & Yes & \\
\hline GRL4 & Chalkidiki & Mavres Petres & Yes & \\
\hline GRL5 & Chalkidiki & Mavres Petres & Yes & \\
\hline PBS & Chalkidiki & Olympiada & Yes & \\
\hline AVE4 & Chalkidiki & Olympiada & Yes & \\
\hline GRL6 & Chalkidiki & Olympiada & Yes & \\
\hline GRL7 & Chalkidiki & Olympiada & Yes & \\
\hline GRL8 & Chalkidiki & Olympiada & Yes & \\
\hline ST-12a & Chalkidiki & Stratoni & Yes & \\
\hline ST-12b & Chalkidiki & Stratoni & Yes & \\
\hline TG25 & Thasos & Agios Eleftherios & Yes & NHG/ZSG \\
\hline KM3 & Thasos & Koumaria & Yes & NHG/ZSG \\
\hline KM2 & Thasos & Koumaria & Yes & NHG/ZSG \\
\hline KM1 & Thasos & Koumaria & Yes & NHG/ZSG \\
\hline MR1 & Thasos & Marlou & Yes & IGME \\
\hline IGME 49 & Thasos & Sotiros & Yes & IGME \\
\hline TG28 Sotir & Thasos & Sotiros & Yes & Gale \\
\hline IGME15 & Pangaeon & Nikisiani Valley & Yes & NHG/ZSG \\
\hline PS13 & Rhodope & Kirki & No & Papastavrou \\
\hline PS5 (GAMMA) & Rhodope & Kirki & No & Papastavrou \\
\hline PS8 (GAMMA) & Rhodope & Kirki & No & Papastavrou \\
\hline PS9 & Rhodope & Kirki & No & Papastavrou \\
\hline PS12 (KA 1)/871 & Rhodope & Kirki & No & Papastavrou \\
\hline PS2 (SP 2) & Rhodope & Kirki & No & Papastavrou \\
\hline 18 & Rhodope & Kalotycho & No & \\
\hline 1 & Rhodope & Saint Philippos & No & \\
\hline PS-2 & Rhodope & Saint Philippos & No & \\
\hline PS-3 & Rhodope & Saint Philippos & No & \\
\hline PS-9 & Rhodope & Saint Philippos & No & \\
\hline PS-12 & Rhodope & Saint Philippos & No & \\
\hline PS-13 & Rhodope & Saint Philippos & No & \\
\hline 2 & Rhodope & Saint Philippos & No & \\
\hline KA-1 & Rhodope & King Arthur & No & \\
\hline 7 & Rhodope & Distrato & No & \\
\hline 8 & Rhodope & Distrato & No & \\
\hline 9 & Rhodope & Distrato & No & \\
\hline 11 & Rhodope & Distrato & No & \\
\hline KA1 & Rhodope & Thermes & No & \\
\hline $\mathrm{Ml} / 2$ & Rhodope & Thermes & No & \\
\hline $\mathrm{RA} / 5$ & Rhodope & Thermes & No & \\
\hline $\mathrm{Ml} / 10$ & Rhodope & Thermes & No & \\
\hline $\mathrm{Ml} / 11$ & Rhodope & Thermes & No & \\
\hline MY-4B & Rhodope & Thermes & No & \\
\hline MY-1 & Rhodope & Thermes & No & \\
\hline$M Y-2 A$ & Rhodope & Thermes & No & \\
\hline MY-12 & Rhodope & Thermes & No & \\
\hline MY-2 & Rhodope & Thermes & No & \\
\hline $\mathrm{MY} / 13 \mathrm{~B}$ & Rhodope & Thermes & No & \\
\hline$M Y-2 A$ & Rhodope & Thermes & No & \\
\hline $\mathrm{MY} / 14 \mathrm{~B}$ & Rhodope & Thermes & No & \\
\hline MY-1E & Rhodope & Thermes & No & \\
\hline MY-3 & Rhodope & Thermes & No & \\
\hline $\mathrm{KI} / 8$ & Rhodope & Thermes & No & \\
\hline 3 & Rhodope & Kirki Tris Vryses & No & \\
\hline MP-41 & Rhodope & Boukates Tris Vryses & No & \\
\hline MP-44 & Rhodope & Boukates Tris Vryses & No & \\
\hline V-129 & Rhodope & Virini & No & \\
\hline 21 & Rhodope & Aisymi & No & \\
\hline 23 & Rhodope & Aisymi & No & \\
\hline
\end{tabular}




$\begin{array}{llll}4 & \text { Rhodope } & \text { Aisymi } & \text { No } \\ 5 & \text { Rhodope } & \text { Aisymi } & \text { No } \\ 6 & \text { Rhodope } & \text { Aisymi } & \text { No } \\ \text { 「A-328A } & \text { Rhodope } & \text { Aisymi } & \text { No } \\ \text { ES-27 } & \text { Rhodope } & \text { Aisymi } & \text { No } \\ \text { NK-17 } & \text { Rhodope } & \text { Aisymi } & \text { No } \\ \text { BB } / 15 & \text { Rhodope } & \text { Thermes } & \text { No }\end{array}$




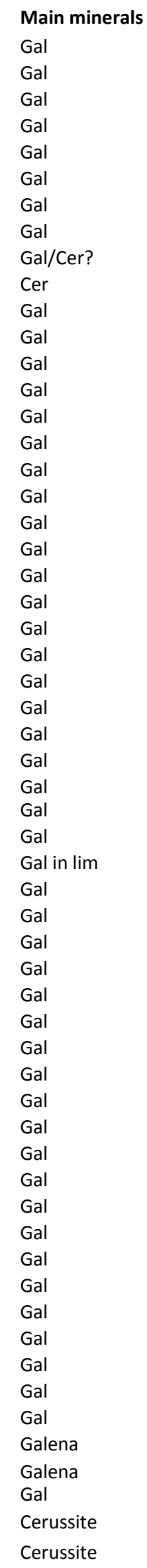

\begin{tabular}{|c|c|}
\hline${ }^{206} \mathrm{~Pb} /{ }^{204} \mathrm{~Pb}$ & ${ }^{207} \mathrm{~Pb} /{ }^{204} \mathrm{~Pb}$ \\
\hline 18.83300 & 15.67094 \\
\hline 18.84600 & 15.67026 \\
\hline 18.85100 & 15.67046 \\
\hline 18.82200 & 15.66329 \\
\hline 18.84200 & 15.66995 \\
\hline 18.87500 & 15.6983 \\
\hline 18.86400 & 15.6727 \\
\hline 18.85100 & 15.68667 \\
\hline 18.83000 & 15.65922 \\
\hline 18.89500 & 15.70250 \\
\hline 18.86600 & 15.68274 \\
\hline 18.83100 & 15.65666 \\
\hline 18.92300 & 15.73693 \\
\hline 18.91588 & 15.72670 \\
\hline 18.90600 & 15.71826 \\
\hline 18.88600 & 15.70692 \\
\hline 18.83100 & 15.66268 \\
\hline 18.82000 & 15.65749 \\
\hline 18.83200 & 15.66841 \\
\hline 18.85700 & 15.67394 \\
\hline 18.87400 & 15.67372 \\
\hline 18.87700 & 15.68641 \\
\hline 18.84900 & 15.68312 \\
\hline 18.84600 & 15.69325 \\
\hline 18.88600 & 15.71372 \\
\hline 18.89700 & 15.70756 \\
\hline 18.91100 & 15.70426 \\
\hline 18.84900 & 15.68312 \\
\hline $\begin{array}{l}18.88200 \\
18.85700\end{array}$ & $\begin{array}{l}15.69415 \\
15.67526\end{array}$ \\
\hline 18.91000 & 15.70797 \\
\hline 18.86810 & 15.69892 \\
\hline 18.82200 & 15.64447 \\
\hline 18.86800 & 15.68704 \\
\hline 18.87200 & 15.69037 \\
\hline 18.85400 & 15.69068 \\
\hline 18.86300 & 15.68194 \\
\hline 18.84300 & 15.67945 \\
\hline 18.84800 & 15.68135 \\
\hline 18.85000 & 15.69677 \\
\hline 18.88500 & 15.69513 \\
\hline 18.85600 & 15.68291 \\
\hline 18.85600 & 15.67744 \\
\hline 18.88400 & 15.68127 \\
\hline 18.86800 & 15.68403 \\
\hline 18.88200 & 15.68603 \\
\hline 18.87800 & 15.68403 \\
\hline 18.66600 & 15.67141 \\
\hline 18.65500 & 15.68214 \\
\hline 18.66800 & 15.66936 \\
\hline 18.66700 & 15.67487 \\
\hline 18.82000 & 15.70000 \\
\hline 18.85000 & 15.72000 \\
\hline 18.82700 & 15.70774 \\
\hline $\begin{array}{l}18.83500 \\
18.71400\end{array}$ & $\begin{array}{l}15.7176 \\
15.6881\end{array}$ \\
\hline 18.73100 & 15.71587 \\
\hline 18.73100 & 15.71587 \\
\hline
\end{tabular}

\begin{tabular}{|c|c|}
\hline${ }^{208} \mathrm{~Pb} /{ }^{204} \mathrm{~Pb}$ & ${ }^{204} \mathrm{~Pb} /{ }^{206} \mathrm{~Pb}$ \\
\hline 38.81670 & 0.05310 \\
\hline 38.82276 & 0.05306 \\
\hline 38.84437 & 0.05305 \\
\hline 38.76014 & 0.05313 \\
\hline 38.80321 & 0.05307 \\
\hline 38.84475 & 0.05298 \\
\hline 38.82023 & 0.05301 \\
\hline 38.80610 & 0.05305 \\
\hline 38.75685 & 0.05311 \\
\hline 38.89933 & 0.05292 \\
\hline 38.86396 & 0.05301 \\
\hline 38.79939 & 0.05310 \\
\hline 38.99254 & 0.05285 \\
\hline 38.97301 & 0.05287 \\
\hline 38.96886 & 0.05289 \\
\hline 38.93991 & 0.05295 \\
\hline 38.80128 & 0.05310 \\
\hline 38.77296 & 0.05313 \\
\hline 38.86360 & 0.05310 \\
\hline 38.83788 & 0.05303 \\
\hline 38.86345 & 0.05298 \\
\hline 38.88284 & 0.05298 \\
\hline 38.85533 & 0.05305 \\
\hline 38.89343 & 0.05306 \\
\hline 38.95936 & 0.05295 \\
\hline 38.95617 & 0.05292 \\
\hline 38.93813 & 0.05288 \\
\hline 38.85533 & 0.05305 \\
\hline $\begin{array}{l}38.83574 \\
38.83618\end{array}$ & $\begin{array}{l}0.05296 \\
0.05303\end{array}$ \\
\hline 38.97540 & 0.05288 \\
\hline 38.88885 & 0.05300 \\
\hline 38.71704 & 0.05313 \\
\hline 38.86242 & 0.05300 \\
\hline 38.87575 & 0.05299 \\
\hline 38.84678 & 0.05304 \\
\hline 38.84212 & 0.05301 \\
\hline 38.82977 & 0.05307 \\
\hline 38.83197 & 0.05306 \\
\hline 38.84476 & 0.05305 \\
\hline 38.89120 & 0.05295 \\
\hline 38.84430 & 0.05303 \\
\hline 38.84393 & 0.05303 \\
\hline 38.82362 & 0.05295 \\
\hline 38.84016 & 0.05300 \\
\hline 38.82328 & 0.05296 \\
\hline 38.84149 & 0.05297 \\
\hline 38.80531 & 0.05357 \\
\hline 38.85146 & 0.05360 \\
\hline 38.78818 & 0.05357 \\
\hline 38.83744 & 0.05357 \\
\hline 38.98000 & 0.05313 \\
\hline 38.92000 & 0.05305 \\
\hline 38.92896 & 0.05312 \\
\hline $\begin{array}{l}38.91951 \\
38.91483\end{array}$ & $\begin{array}{l}0.05309 \\
0.05344\end{array}$ \\
\hline 38.98633 & 0.05339 \\
\hline 38.98633 & 0.0533 \\
\hline
\end{tabular}

\begin{tabular}{|c|c|}
\hline${ }^{207} \mathrm{~Pb} /{ }^{206} \mathrm{~Pb}$ & ${ }^{208} \mathrm{~Pb} /{ }^{206} \mathrm{~Pb}$ \\
\hline 0.83210 & 2.06110 \\
\hline 0.83149 & 2.06000 \\
\hline 0.83128 & 2.06060 \\
\hline 0.83218 & 2.05930 \\
\hline 0.83165 & 2.05940 \\
\hline 0.83170 & 2.05800 \\
\hline 0.83083 & 2.05790 \\
\hline 0.83214 & 2.05857 \\
\hline 0.83161 & 2.05825 \\
\hline 0.83104 & 2.05871 \\
\hline 0.83127 & 2.06000 \\
\hline 0.83143 & 2.06040 \\
\hline 0.83163 & 2.06059 \\
\hline 0.83140 & 2.06033 \\
\hline 0.83139 & 2.06119 \\
\hline 0.83167 & 2.06184 \\
\hline 0.83175 & 2.06050 \\
\hline 0.83196 & 2.06020 \\
\hline 0.83201 & 2.06370 \\
\hline 0.83120 & 2.05960 \\
\hline 0.83044 & 2.05910 \\
\hline 0.83098 & 2.05980 \\
\hline 0.83204 & 2.06140 \\
\hline 0.83271 & 2.06375 \\
\hline 0.83203 & 2.06287 \\
\hline 0.83122 & 2.06150 \\
\hline 0.83043 & 2.05902 \\
\hline 0.83204 & 2.06140 \\
\hline 0.83117 & 2.05676 \\
\hline 0.83127 & 2.05951 \\
\hline 0.83067 & 2.06110 \\
\hline 0.83204 & 2.06109 \\
\hline 0.83118 & 2.05701 \\
\hline 0.83141 & 2.05970 \\
\hline 0.83141 & 2.05997 \\
\hline 0.83222 & 2.06040 \\
\hline 0.83136 & 2.05917 \\
\hline 0.83211 & 2.06070 \\
\hline 0.83199 & 2.06027 \\
\hline 0.83272 & 2.06073 \\
\hline 0.83109 & 2.05937 \\
\hline 0.83172 & 2.06005 \\
\hline 0.83143 & 2.06003 \\
\hline 0.83040 & 2.05590 \\
\hline 0.83125 & 2.05852 \\
\hline 0.83074 & 2.05610 \\
\hline 0.83081 & 2.05750 \\
\hline 0.83957 & 2.07893 \\
\hline 0.84064 & 2.08263 \\
\hline 0.83937 & 2.07779 \\
\hline 0.83971 & 2.08054 \\
\hline 0.83422 & 2.07120 \\
\hline 0.83395 & 2.06472 \\
\hline 0.83432 & 2.06772 \\
\hline $\begin{array}{l}0.83449 \\
0.83831\end{array}$ & $\begin{array}{l}2.06634 \\
2.07945\end{array}$ \\
\hline 0.83903 & 2.08138 \\
\hline 0.83903 & 2.08138 \\
\hline
\end{tabular}




\begin{tabular}{|c|c|c|c|c|c|c|}
\hline \multirow[t]{10}{*}{ Jar, Lim } & 18.72000 & 15.68923 & 38.90952 & 0.05342 & 0.83810 & 2.07850 \\
\hline & 18.74100 & 15.71414 & 38.97716 & 0.05336 & 0.83849 & 2.07978 \\
\hline & 18.72300 & 15.69530 & 38.93822 & 0.05341 & 0.83829 & 2.07970 \\
\hline & 18.74300 & 15.71582 & 38.98413 & 0.05335 & 0.83849 & 2.07993 \\
\hline & 18.73500 & 15.69937 & 38.92327 & 0.05338 & 0.83797 & 2.07757 \\
\hline & 18.76200 & 15.73100 & 39.06961 & 0.05330 & 0.83845 & 2.08238 \\
\hline & 18.75700 & 15.72343 & 39.00368 & 0.05331 & 0.83827 & 2.08238 \\
\hline & 18.77500 & 15.74303 & 39.06327 & 0.05326 & 0.83851 & 2.07942 \\
\hline & 18.75200 & 15.71924 & 39.03923 & 0.05333 & 0.83827 & 2.08060 \\
\hline & 18.76300 & 15.73052 & 38.98764 & 0.05330 & 0.83838 & 2.08187 \\
\hline Jar & 18.73000 & 15.69012 & 38.65760 & 0.05339 & 0.83770 & 2.07790 \\
\hline Gal & 18.91966 & 15.71751 & 39.04904 & 0.05286 & 0.83075 & 2.06394 \\
\hline Gal & 18.90038 & 15.69771 & 38.96861 & 0.05291 & 0.83055 & 2.06179 \\
\hline Gal & 18.90270 & 15.70436 & 38.98871 & 0.05290 & 0.83080 & 2.06260 \\
\hline Gal & 18.90208 & 15.70196 & 38.98252 & 0.05290 & 0.83070 & 2.06234 \\
\hline Gal & 18.89985 & 15.69481 & 38.96053 & 0.05291 & 0.83042 & 2.06142 \\
\hline Gal & 18.89989 & 15.69598 & 38.96420 & 0.05291 & 0.83048 & 2.06161 \\
\hline Gal & 18.90150 & 15.69770 & 38.97168 & 0.05291 & 0.83050 & 2.06183 \\
\hline Gal & 18.90088 & 15.69548 & 38.96605 & 0.05291 & 0.83041 & 2.06160 \\
\hline Gal & 18.89630 & 15.69187 & 38.95151 & 0.05292 & 0.83042 & 2.06133 \\
\hline Gal & 18.89941 & 15.69672 & 38.96718 & 0.05291 & 0.83054 & 2.06182 \\
\hline Gal & 18.90103 & 15.69882 & 38.97071 & 0.05291 & 0.83058 & 2.06183 \\
\hline Gal & 18.89477 & 15.69267 & 38.94911 & 0.05292 & 0.83053 & 2.06137 \\
\hline Gal & 18.91158 & 15.71401 & 39.02386 & 0.05288 & 0.83092 & 2.06349 \\
\hline Gal & 18.89356 & 15.69129 & 38.94605 & 0.05293 & 0.83051 & 2.06134 \\
\hline Gal & 18.89610 & 15.69038 & 38.94297 & 0.05292 & 0.83035 & 2.06090 \\
\hline Gal & 18.89650 & 15.69430 & 38.95438 & 0.05292 & 0.83054 & 2.06146 \\
\hline Gal & 18.89580 & 15.69069 & 38.94065 & 0.05292 & 0.83038 & 2.06081 \\
\hline Gal & 18.89770 & 15.69397 & 38.95232 & 0.05292 & 0.83047 & 2.06122 \\
\hline Gal & 18.89386 & 15.68965 & 38.94119 & 0.05293 & 0.83041 & 2.06105 \\
\hline Gal & 18.89970 & 15.69507 & 38.96230 & 0.05291 & 0.83044 & 2.06153 \\
\hline Gal & 18.89366 & 15.69402 & 39.01050 & 0.05293 & 0.83065 & 2.06474 \\
\hline Gal & 18.89760 & 15.70088 & 39.03167 & 0.05292 & 0.83084 & 2.06543 \\
\hline Gal & 18.89457 & 15.69704 & 39.01785 & 0.05293 & 0.83077 & 2.06503 \\
\hline Gal & 18.87900 & 15.67580 & 38.93095 & 0.05297 & 0.83033 & 2.06213 \\
\hline Gal & 18.90160 & 15.70080 & 38.97869 & 0.05291 & 0.83066 & 2.06219 \\
\hline Gal & 18.89860 & 15.71135 & 39.01087 & 0.05291 & 0.83135 & 2.06422 \\
\hline Gal & 18.89460 & 15.69197 & 38.95008 & 0.05293 & 0.83050 & 2.06144 \\
\hline Gal & 18.91900 & 15.71242 & 39.04876 & 0.05286 & 0.83051 & 2.06400 \\
\hline Gal & 18.89200 & 15.68584 & 38.95568 & 0.05293 & 0.83029 & 2.06202 \\
\hline Gal & 18.88500 & 15.67946 & 38.94805 & 0.05295 & 0.83026 & 2.06238 \\
\hline Gal & 18.94200 & 15.73967 & 39.08568 & 0.05279 & 0.83094 & 2.06344 \\
\hline Gal & 18.88770 & 15.68982 & 38.97987 & 0.05294 & 0.83069 & 2.06377 \\
\hline Gal & 18.90060 & 15.70394 & 39.01689 & 0.05291 & 0.83087 & 2.06432 \\
\hline Gal & 18.89623 & 15.69804 & 38.96762 & 0.05292 & 0.83075 & 2.06219 \\
\hline Gal & 18.90148 & 15.70014 & 38.97788 & 0.05291 & 0.83063 & 2.06216 \\
\hline Gal & 18.89300 & 15.69366 & 38.98948 & 0.05293 & 0.83066 & 2.06370 \\
\hline Gal & 18.89885 & 15.70116 & 39.01497 & 0.05291 & 0.83080 & 2.06441 \\
\hline Gal & 18.89650 & 15.70072 & 39.00255 & 0.05292 & 0.83088 & 2.06401 \\
\hline Gal & 18.93788 & 15.74457 & 39.15994 & 0.05280 & 0.83138 & 2.06781 \\
\hline Gal & 18.87880 & 15.68356 & 38.96282 & 0.05297 & 0.83075 & 2.06384 \\
\hline Gal & 18.90900 & 15.71226 & 39.05085 & 0.05288 & 0.83094 & 2.06520 \\
\hline Gal & 18.89460 & 15.69442 & 38.98712 & 0.05293 & 0.83063 & 2.06340 \\
\hline Gal & 18.92000 & 15.71476 & 39.05788 & 0.05285 & 0.83059 & 2.06437 \\
\hline Gal & 18.89300 & 15.69196 & 38.96776 & 0.05293 & 0.83057 & 2.06255 \\
\hline Gal & 18.90399 & 15.69863 & 38.97681 & 0.05290 & 0.83044 & 2.06183 \\
\hline Gal & 18.90091 & 15.69683 & 38.96725 & 0.05291 & 0.83048 & 2.06166 \\
\hline
\end{tabular}




\begin{tabular}{|c|c|c|c|c|c|c|}
\hline Gal & 18.89600 & 15.69426 & 39.00890 & 0.05292 & 0.83056 & 2.06440 \\
\hline Gal & 18.90090 & 15.69172 & 38.98046 & 0.05291 & 0.83021 & 2.06236 \\
\hline Gal & 18.90862 & 15.71155 & 39.00073 & 0.05289 & 0.83092 & 2.06259 \\
\hline Gal & 18.92300 & 15.73315 & 39.11971 & 0.05285 & 0.83143 & 2.06731 \\
\hline Gal & 18.90640 & 15.70763 & 39.04398 & 0.05289 & 0.83081 & 2.06512 \\
\hline Gal & 18.90376 & 15.70751 & 39.03418 & 0.05290 & 0.83092 & 2.06489 \\
\hline Gal & 18.89000 & 15.68437 & 38.96629 & 0.05294 & 0.83030 & 2.06280 \\
\hline Gal & 18.92740 & 15.72280 & 39.08773 & 0.05283 & 0.83069 & 2.06514 \\
\hline Gal & 18.85600 & 15.64388 & 38.82620 & 0.05303 & 0.82965 & 2.05909 \\
\hline Gal & 18.86100 & 15.64897 & 38.84178 & 0.05302 & 0.82970 & 2.05937 \\
\hline Gal & 18.91560 & 15.71987 & 39.08303 & 0.05287 & 0.83105 & 2.06618 \\
\hline Gal & 18.89870 & 15.70085 & 39.01712 & 0.05291 & 0.83079 & 2.06454 \\
\hline \multirow[t]{2}{*}{ Gal } & 18.85200 & 15.66733 & 38.90148 & 0.05304 & 0.83107 & 2.06352 \\
\hline & 18.88200 & 15.70095 & 39.06138 & 0.05296 & 0.83153 & 2.06871 \\
\hline Gal & 18.79800 & 15.66776 & 38.93611 & 0.05320 & 0.83348 & 2.07129 \\
\hline Gal & 18.80000 & 15.67450 & 38.95398 & 0.05319 & 0.83375 & 2.07202 \\
\hline Gal & 18.80000 & 15.67807 & 38.95266 & 0.05319 & 0.83394 & 2.07195 \\
\hline Gal & 18.85400 & 15.72254 & 39.12375 & 0.05304 & 0.83391 & 2.07509 \\
\hline Gal & 18.78500 & 15.66876 & 38.92308 & 0.05323 & 0.83411 & 2.07203 \\
\hline Gal & 18.78000 & 15.66421 & 38.90333 & 0.05325 & 0.83409 & 2.07153 \\
\hline Gal & 18.80300 & 15.69186 & 38.99441 & 0.05318 & 0.83454 & 2.07384 \\
\hline Gal & 18.80700 & 15.69670 & 39.02208 & 0.05317 & 0.83462 & 2.07487 \\
\hline Gal & 18.78100 & 15.66429 & 38.90879 & 0.05325 & 0.83405 & 2.07171 \\
\hline Gal & 18.80200 & 15.69121 & 38.99610 & 0.05319 & 0.83455 & 2.07404 \\
\hline Gal & 18.78800 & 15.67295 & 38.93024 & 0.05323 & 0.83420 & 2.07208 \\
\hline Gal & 18.81800 & 15.70419 & 39.03568 & 0.05314 & 0.83453 & 2.07438 \\
\hline Gal & 18.80600 & 15.68345 & 38.97562 & 0.05317 & 0.83396 & 2.07251 \\
\hline Gal & 18.80300 & 15.68076 & 38.95718 & 0.05318 & 0.83395 & 2.07186 \\
\hline Gal & 18.84200 & 15.70933 & 39.08113 & 0.05307 & 0.83374 & 2.07415 \\
\hline Gal & 18.80500 & 15.69653 & 39.00627 & 0.05318 & 0.83470 & 2.07425 \\
\hline Gal & 18.93700 & 15.69593 & 39.00151 & 0.05281 & 0.82885 & 2.05954 \\
\hline Gal & 18.94000 & 15.69804 & 39.01337 & 0.05280 & 0.82883 & 2.05984 \\
\hline Gal & 18.92700 & 15.67212 & 38.93587 & 0.05283 & 0.82803 & 2.05716 \\
\hline Gal & 18.98700 & 15.74649 & 39.17967 & 0.05267 & 0.82933 & 2.06350 \\
\hline Gal & 18.81700 & 15.72593 & 39.14670 & 0.05314 & 0.83573 & 2.08039 \\
\hline Gal & 18.82200 & 15.71468 & 39.08934 & 0.05313 & 0.83491 & 2.07679 \\
\hline Gal & 18.81535 & 15.70988 & 39.08456 & 0.05315 & 0.83495 & 2.07727 \\
\hline Gal & 18.80900 & 15.71097 & 39.08585 & 0.05317 & 0.83529 & 2.07804 \\
\hline Gal & 18.82007 & 15.72774 & 39.15196 & 0.05313 & 0.83569 & 2.08033 \\
\hline Gal & 18.81500 & 15.71598 & 39.10321 & 0.05315 & 0.83529 & 2.07830 \\
\hline Gal & 18.82000 & 15.71602 & 39.10570 & 0.05313 & 0.83507 & 2.07788 \\
\hline Gal & 18.81550 & 15.72298 & 39.13492 & 0.05315 & 0.83564 & 2.07993 \\
\hline Gal & 18.81400 & 15.71477 & 39.11619 & 0.05315 & 0.83527 & 2.07910 \\
\hline Gal & 18.81500 & 15.70714 & 39.08289 & 0.05315 & 0.83482 & 2.07722 \\
\hline Gal & 18.81800 & 15.71341 & 39.09327 & 0.05314 & 0.83502 & 2.07744 \\
\hline Gal & 18.81250 & 15.71201 & 39.09125 & 0.05316 & 0.83519 & 2.07794 \\
\hline Gal & 18.83200 & 15.73395 & 39.16227 & 0.05310 & 0.83549 & 2.07956 \\
\hline Gal & 18.82700 & 15.72958 & 39.13456 & 0.05312 & 0.83548 & 2.07864 \\
\hline Gal & 18.91400 & 15.73153 & 39.14177 & 0.05287 & 0.83174 & 2.06946 \\
\hline Gal & 18.91700 & 15.73819 & 39.16311 & 0.05286 & 0.83196 & 2.07026 \\
\hline Gal & 18.98300 & 15.72381 & 39.14352 & 0.05268 & 0.82831 & 2.06203 \\
\hline Gal & 18.99500 & 15.73318 & 39.16579 & 0.05265 & 0.82828 & 2.06190 \\
\hline Gal & 18.94601 & 15.66702 & 38.94693 & 0.05278 & 0.82693 & 2.05568 \\
\hline Gal & 18.96200 & 15.68954 & 39.01962 & 0.05274 & 0.82742 & 2.05778 \\
\hline Gal & 18.97400 & 15.70231 & 39.06595 & 0.05270 & 0.82757 & 2.05892 \\
\hline Gal & 18.97500 & 15.70618 & 39.07617 & 0.05270 & 0.82773 & 2.05935 \\
\hline Gal & 18.97000 & 15.69843 & 39.05373 & 0.05271 & 0.82754 & 2.05871 \\
\hline Gal & 18.96820 & 15.68765 & 39.01892 & 0.05272 & 0.82705 & 2.05707 \\
\hline Gal & 18.97200 & 15.70161 & 39.06126 & 0.05271 & 0.82762 & 2.05889 \\
\hline
\end{tabular}




\begin{tabular}{|c|c|c|c|c|c|c|}
\hline Gal & 18.99210 & 15.70894 & 39.08836 & 0.05265 & 0.82713 & 2.05814 \\
\hline Gal & 18.98770 & 15.70985 & 39.09112 & 0.05267 & 0.82737 & 2.05876 \\
\hline Gal & 18.88300 & 15.70745 & 39.04683 & 0.05296 & 0.83183 & 2.06783 \\
\hline Gal & 18.90300 & 15.70083 & 39.02619 & 0.05290 & 0.83060 & 2.06455 \\
\hline Gal & 18.89900 & 15.69600 & 39.00999 & 0.05291 & 0.83052 & 2.06413 \\
\hline Gal & 18.91260 & 15.71185 & 39.06848 & 0.05287 & 0.83076 & 2.06574 \\
\hline Gal & 18.89350 & 15.70554 & 39.05371 & 0.05293 & 0.83127 & 2.06705 \\
\hline Gal & 18.89902 & 15.70603 & 39.09877 & 0.05291 & 0.83105 & 2.06883 \\
\hline Gal & 18.94620 & 15.74391 & 39.18151 & 0.05278 & 0.83098 & 2.06804 \\
\hline Gal & 18.93200 & 15.72706 & 39.12752 & 0.05282 & 0.83071 & 2.06674 \\
\hline Gal & 18.89633 & 15.69306 & 39.00921 & 0.05292 & 0.83048 & 2.06438 \\
\hline Gal & 18.90430 & 15.69378 & 39.01545 & 0.05290 & 0.83017 & 2.06384 \\
\hline Gal & 18.91605 & 15.70732 & 39.05483 & 0.05287 & 0.83037 & 2.06464 \\
\hline Gal & 18.94170 & 15.74211 & 39.18147 & 0.05279 & 0.83108 & 2.06853 \\
\hline Gal & 18.91300 & 15.70422 & 39.05221 & 0.05287 & 0.83034 & 2.06483 \\
\hline Gal & 18.91170 & 15.70389 & 39.04517 & 0.05288 & 0.83038 & 2.06460 \\
\hline Gal & 18.90200 & 15.68620 & 38.89559 & 0.05290 & 0.82987 & 2.05775 \\
\hline Gal & 18.85300 & 15.69361 & 38.97669 & 0.05304 & 0.83242 & 2.06740 \\
\hline Gal & 18.86700 & 15.69300 & 38.99884 & 0.05300 & 0.83177 & 2.06704 \\
\hline Gal & 17.83300 & 15.61083 & 37.87480 & 0.05608 & 0.87539 & 2.12386 \\
\hline Gal & 17.85800 & 15.61986 & 37.98164 & 0.05600 & 0.87467 & 2.12687 \\
\hline Gal & 18.87200 & 15.67961 & 38.86839 & 0.05299 & 0.83084 & 2.05958 \\
\hline Gal & 18.79900 & 15.68325 & 38.94871 & 0.05319 & 0.83426 & 2.07185 \\
\hline Gal & 18.81100 & 15.70004 & 38.99859 & 0.05316 & 0.83462 & 2.07318 \\
\hline Gal & 18.80000 & 15.68597 & 38.94721 & 0.05319 & 0.83436 & 2.07166 \\
\hline Gal & 18.83100 & 15.72163 & 39.07941 & 0.05310 & 0.83488 & 2.07527 \\
\hline Gal & 18.84700 & 15.72688 & 39.09999 & 0.05306 & 0.83445 & 2.07460 \\
\hline Gal & 18.82700 & 15.71132 & 39.03854 & 0.05312 & 0.83451 & 2.07354 \\
\hline Gal & 18.83900 & 15.72378 & 39.08395 & 0.05308 & 0.83464 & 2.07463 \\
\hline Gal & 18.87070 & 15.69217 & 38.96994 & 0.05299 & 0.83156 & 2.06510 \\
\hline Gal & 18.86830 & 15.68573 & 38.94851 & 0.05300 & 0.83133 & 2.06423 \\
\hline Gal & 18.90500 & 15.74106 & 39.13751 & 0.05290 & 0.83264 & 2.07022 \\
\hline Gal & 18.88100 & 15.71579 & 39.05610 & 0.05296 & 0.83236 & 2.06854 \\
\hline Gal & 18.86040 & 15.69166 & 38.97803 & 0.05302 & 0.83199 & 2.06666 \\
\hline Gal & 18.87060 & 15.69770 & 39.00610 & 0.05299 & 0.83186 & 2.06703 \\
\hline Gal & 18.86800 & 15.69063 & 38.97242 & 0.05300 & 0.83160 & 2.06553 \\
\hline Gal & 18.85590 & 15.67340 & 38.91537 & 0.05303 & 0.83122 & 2.06383 \\
\hline Gal & 18.86100 & 15.68896 & 38.91741 & 0.05302 & 0.83182 & 2.06338 \\
\hline Gal & 18.86400 & 15.68919 & 38.94680 & 0.05301 & 0.83170 & 2.06461 \\
\hline Gal & 18.86100 & 15.68443 & 38.92722 & 0.05302 & 0.83158 & 2.06390 \\
\hline Gal & 18.83900 & 15.66745 & 38.87202 & 0.05308 & 0.83165 & 2.06338 \\
\hline Gal & 18.85800 & 15.69118 & 38.95007 & 0.05303 & 0.83207 & 2.06544 \\
\hline Gal & 18.86400 & 15.68315 & 38.94586 & 0.05301 & 0.83138 & 2.06456 \\
\hline Gal & 18.88300 & 15.70688 & 39.02399 & 0.05296 & 0.83180 & 2.06662 \\
\hline Gal & 18.85400 & 15.67182 & 38.86809 & 0.05304 & 0.83122 & 2.06153 \\
\hline Gal & 18.89300 & 15.72710 & 39.09321 & 0.05293 & 0.83243 & 2.06919 \\
\hline Gal & 18.87400 & 15.70260 & 39.01482 & 0.05298 & 0.83197 & 2.06712 \\
\hline Gal & 18.87340 & 15.70399 & 39.01509 & 0.05298 & 0.83207 & 2.06720 \\
\hline Gal & 18.92000 & 15.75393 & 39.18086 & 0.05285 & 0.83266 & 2.07087 \\
\hline Gal & 18.87300 & 15.69611 & 38.99539 & 0.05299 & 0.83167 & 2.06620 \\
\hline Gal & 18.88600 & 15.71107 & 39.04189 & 0.05295 & 0.83189 & 2.06724 \\
\hline Gal & 18.90500 & 15.72537 & 39.09081 & 0.05290 & 0.83181 & 2.06775 \\
\hline Gal & 18.86760 & 15.69181 & 38.97650 & 0.05300 & 0.83168 & 2.06579 \\
\hline Gal & 18.87200 & 15.69716 & 38.99408 & 0.05299 & 0.83177 & 2.06624 \\
\hline Gal & 18.86800 & 15.69346 & 38.98261 & 0.05300 & 0.83175 & 2.06607 \\
\hline Gal & 18.87500 & 15.70174 & 39.01161 & 0.05298 & 0.83188 & 2.06684 \\
\hline Gal & 18.87200 & 15.69848 & 38.99823 & 0.05299 & 0.83184 & 2.06646 \\
\hline Gal & 18.88100 & 15.70616 & 39.02136 & 0.05296 & 0.83185 & 2.06670 \\
\hline Gal & 18.89000 & 15.71535 & 39.05640 & 0.05294 & 0.83194 & 2.06757 \\
\hline
\end{tabular}




\begin{tabular}{|c|c|c|c|c|c|c|}
\hline Gal & 18.89200 & 15.71833 & 39.06563 & 0.05293 & 0.83201 & 2.06784 \\
\hline Gal & 18.86500 & 15.69002 & 38.97452 & 0.05301 & 0.83170 & 2.06597 \\
\hline Gal & 18.86350 & 15.70526 & 38.99280 & 0.05301 & 0.83257 & 2.06710 \\
\hline Gal & 18.87520 & 15.70907 & 39.02466 & 0.05298 & 0.83226 & 2.06751 \\
\hline Gal & 18.89640 & 15.72275 & 39.07152 & 0.05292 & 0.83205 & 2.06767 \\
\hline Gal & 18.87640 & 15.69373 & 38.97826 & 0.05298 & 0.83139 & 2.06492 \\
\hline Gal & 18.87230 & 15.70024 & 38.99489 & 0.05299 & 0.83192 & 2.06625 \\
\hline Cpy /Gal & 18.42368 & 15.71899 & 38.68335 & 0.05428 & 0.85319 & 2.09965 \\
\hline Cpy /Gal & 18.40022 & 15.68807 & 38.58194 & 0.05435 & 0.85260 & 2.09682 \\
\hline Cpy /Gal & 18.43211 & 15.72742 & 38.71496 & 0.05425 & 0.85326 & 2.10041 \\
\hline Cpy /Gal & 18.43145 & 15.72592 & 38.71176 & 0.05426 & 0.85321 & 2.10031 \\
\hline Cpy /Gal & 18.42808 & 15.72204 & 38.70098 & 0.05427 & 0.85316 & 2.10011 \\
\hline Gal & 18.40000 & 15.69097 & 38.53714 & 0.05435 & 0.85277 & 2.09441 \\
\hline Gal & 18.41300 & 15.70758 & 38.58776 & 0.05431 & 0.85307 & 2.09568 \\
\hline Gal & 18.40408 & 15.69621 & 38.61029 & 0.05434 & 0.85287 & 2.09792 \\
\hline Gal & 18.39978 & 15.67459 & 38.53499 & 0.05435 & 0.85189 & 2.09432 \\
\hline Gal & 18.42058 & 15.69804 & 38.61344 & 0.05429 & 0.85220 & 2.09621 \\
\hline Gal & 18.42629 & 15.70502 & 38.63517 & 0.05427 & 0.85232 & 2.09674 \\
\hline Gal & 18.42629 & 15.70502 & 38.63517 & 0.05427 & 0.85232 & 2.09674 \\
\hline Gal & 18.39600 & 15.67946 & 38.50485 & 0.05436 & 0.85233 & 2.09311 \\
\hline Gal & 18.44337 & 15.72703 & 38.70826 & 0.05422 & 0.85272 & 2.09876 \\
\hline Gal & 18.21100 & 15.61648 & 38.29628 & 0.05491 & 0.85753 & 2.10292 \\
\hline Gal & 18.23300 & 15.64391 & 38.38539 & 0.05485 & 0.85800 & 2.10527 \\
\hline Gal & 18.23200 & 15.64233 & 38.35174 & 0.05485 & 0.85796 & 2.10354 \\
\hline Gal & 18.79900 & 15.68983 & 38.95754 & 0.05319 & 0.83461 & 2.07232 \\
\hline Gal & 18.79890 & 15.69558 & 38.97181 & 0.05319 & 0.83492 & 2.07309 \\
\hline Gal & 18.80288 & 15.69514 & 38.97367 & 0.05318 & 0.83472 & 2.07275 \\
\hline Gal & 18.81050 & 15.70620 & 39.01824 & 0.05316 & 0.83497 & 2.07428 \\
\hline Gal & 18.81830 & 15.71385 & 39.03405 & 0.05314 & 0.83503 & 2.07426 \\
\hline Gal & 18.79506 & 15.68955 & 38.95671 & 0.05321 & 0.83477 & 2.07271 \\
\hline Gal & 18.80120 & 15.69693 & 38.97884 & 0.05319 & 0.83489 & 2.07321 \\
\hline Gal & 18.82165 & 15.72041 & 39.05586 & 0.05313 & 0.83523 & 2.07505 \\
\hline goeth, cer & 18.86698 & 15.70443 & 39.02521 & 0.05300 & 0.83238 & 2.06840 \\
\hline Gal & 18.60100 & 15.67023 & 38.97709 & 0.05376 & 0.84244 & 2.09543 \\
\hline Gal & 18.82300 & 15.68900 & 38.98900 & 0.05313 & 0.83350 & 2.07135 \\
\hline Gal & 18.82500 & 15.69400 & 38.99100 & 0.05312 & 0.83368 & 2.07124 \\
\hline Gal & 18.79000 & 15.68100 & 38.95900 & 0.05322 & 0.83454 & 2.07339 \\
\hline Gal & 18.82000 & 15.68700 & 38.96600 & 0.05313 & 0.83353 & 2.07046 \\
\hline Gal & 18.85500 & 15.73100 & 39.11300 & 0.05304 & 0.83431 & 2.07441 \\
\hline Gal & 18.84900 & 15.72100 & 39.07300 & 0.05305 & 0.83405 & 2.07295 \\
\hline Gal & 18.82300 & 15.72500 & 39.10600 & 0.05313 & 0.83541 & 2.07756 \\
\hline Gal & 18.85500 & 15.73000 & 39.11500 & 0.05304 & 0.83426 & 2.07452 \\
\hline Gal & 18.77900 & 15.66900 & 38.91300 & 0.05325 & 0.83439 & 2.07216 \\
\hline Gal & 18.77800 & 15.66400 & 38.86100 & 0.05325 & 0.83417 & 2.06950 \\
\hline Gal & 18.72700 & 15.65900 & 38.88100 & 0.05340 & 0.83617 & 2.07620 \\
\hline Gal & 18.79800 & 15.66400 & 38.89400 & 0.05320 & 0.83328 & 2.06905 \\
\hline Gal & 18.77600 & 15.65700 & 38.87500 & 0.05326 & 0.83388 & 2.07046 \\
\hline Gal & 18.76800 & 15.65400 & 38.87100 & 0.05328 & 0.83408 & 2.07113 \\
\hline Gal & 18.77700 & 15.66700 & 38.90800 & 0.05326 & 0.83437 & 2.07211 \\
\hline Gal & 18.77300 & 15.66900 & 38.91400 & 0.05327 & 0.83466 & 2.07287 \\
\hline Gal & 18.81800 & 15.70300 & 39.04500 & 0.05314 & 0.83447 & 2.07488 \\
\hline Gal & 18.78200 & 15.66900 & 38.91400 & 0.05324 & 0.83426 & 2.07188 \\
\hline Gal & 18.78000 & 15.67000 & 38.91000 & 0.05325 & 0.83440 & 2.07188 \\
\hline Gal & 18.78000 & 15.66500 & 38.87600 & 0.05325 & 0.83413 & 2.07007 \\
\hline Gal & 18.81000 & 15.67000 & 38.88000 & 0.05316 & 0.83307 & 2.06699 \\
\hline Gal & 18.79500 & 15.67400 & 38.88900 & 0.05321 & 0.83395 & 2.06911 \\
\hline Gal & 18.78000 & 15.65900 & 38.86800 & 0.05325 & 0.83381 & 2.06965 \\
\hline Gal & 18.78000 & 15.66000 & 38.88000 & 0.05325 & 0.83387 & 2.07029 \\
\hline Gal & 18.78000 & 15.66000 & 38.91000 & 0.05325 & 0.83387 & 2.07188 \\
\hline
\end{tabular}




\begin{tabular}{|c|c|c|c|c|c|c|}
\hline Gal & 18.76000 & 15.62000 & 38.77000 & 0.05330 & 0.83262 & 2.06663 \\
\hline Gal & 18.81000 & 15.67000 & 38.90000 & 0.05316 & 0.83307 & 2.06805 \\
\hline Gal & 18.81000 & 15.66000 & 38.90000 & 0.05316 & 0.83254 & 2.06805 \\
\hline Gal & 18.77100 & 15.66200 & 38.84000 & 0.05327 & 0.83437 & 2.06915 \\
\hline Gal & 18.78000 & 15.67100 & 38.84400 & 0.05325 & 0.83445 & 2.06837 \\
\hline Gal & 18.78000 & 15.68000 & 38.90000 & 0.05325 & 0.83493 & 2.07135 \\
\hline Gal & 18.79000 & 15.68000 & 38.91000 & 0.05322 & 0.83449 & 2.07078 \\
\hline Gal & 18.78000 & 15.67000 & 38.89000 & 0.05325 & 0.83440 & 2.07082 \\
\hline Gal & 18.77600 & 15.65700 & 38.86200 & 0.05326 & 0.83388 & 2.06977 \\
\hline Gal & 18.78500 & 15.66600 & 38.88600 & 0.05323 & 0.83396 & 2.07006 \\
\hline Gal & 18.75100 & 15.64133 & 38.78719 & 0.05333 & 0.83416 & 2.06854 \\
\hline Gal & 18.77400 & 15.67028 & 38.87870 & 0.05327 & 0.83468 & 2.07088 \\
\hline Gal & 18.78100 & 15.68251 & 38.89883 & 0.05325 & 0.83502 & 2.07118 \\
\hline Gal & 18.76400 & 15.66062 & 38.82384 & 0.05329 & 0.83461 & 2.06906 \\
\hline Gal & 18.78000 & 15.66365 & 38.82314 & 0.05325 & 0.83406 & 2.06726 \\
\hline Gal & 18.78200 & 15.66588 & 38.84906 & 0.05324 & 0.83409 & 2.06842 \\
\hline Gal & 18.77800 & 15.65916 & 38.86558 & 0.05325 & 0.83391 & 2.06974 \\
\hline Gal & 18.70700 & 15.68096 & 38.80992 & 0.05346 & 0.83824 & 2.07462 \\
\hline Gal & 18.72900 & 15.64995 & 38.76959 & 0.05339 & 0.83560 & 2.07003 \\
\hline Gal & 18.69600 & 15.65827 & 38.81682 & 0.05349 & 0.83752 & 2.07621 \\
\hline Gal & 18.68600 & 15.63981 & 38.75420 & 0.05352 & 0.83698 & 2.07397 \\
\hline Gal & 18.68600 & 15.63869 & 38.76672 & 0.05352 & 0.83692 & 2.07464 \\
\hline Gal & 18.72800 & 15.64893 & 38.74711 & 0.05340 & 0.83559 & 2.06894 \\
\hline Gal & 18.69000 & 15.63923 & 38.76437 & 0.05350 & 0.83677 & 2.07407 \\
\hline Gal & 18.64500 & 15.69400 & 38.91800 & 0.05363 & 0.84173 & 2.08732 \\
\hline Gal & 18.72100 & 15.67600 & 38.92200 & 0.05342 & 0.83735 & 2.07906 \\
\hline Gal & 18.70100 & 15.65000 & 38.80600 & 0.05347 & 0.83685 & 2.07508 \\
\hline Gal & 18.70400 & 15.65700 & 38.83400 & 0.05346 & 0.83709 & 2.07624 \\
\hline Gal & 18.68600 & 15.63900 & 38.76700 & 0.05352 & 0.83694 & 2.07465 \\
\hline Gal & 18.73000 & 15.64800 & 38.75300 & 0.05339 & 0.83545 & 2.06903 \\
\hline Gal & 18.72900 & 15.64900 & 38.76900 & 0.05339 & 0.83555 & 2.07000 \\
\hline Gal & 18.73000 & 15.65300 & 38.77200 & 0.05339 & 0.83572 & 2.07005 \\
\hline Gal & 18.76900 & 15.65000 & 38.76900 & 0.05328 & 0.83382 & 2.06559 \\
\hline Gal & 18.68800 & 15.65900 & 38.91500 & 0.05351 & 0.83792 & 2.08235 \\
\hline Gal & 18.71600 & 15.67700 & 38.97600 & 0.05343 & 0.83763 & 2.08250 \\
\hline Gal & 18.71200 & 15.69000 & 39.01700 & 0.05344 & 0.83850 & 2.08513 \\
\hline Gal & 18.75400 & 15.74000 & 39.18500 & 0.05332 & 0.83929 & 2.08942 \\
\hline Gal & 18.69800 & 15.65900 & 38.91500 & 0.05348 & 0.83747 & 2.08124 \\
\hline Gal & 18.69500 & 15.66100 & 38.93400 & 0.05349 & 0.83771 & 2.08259 \\
\hline Gal & 18.69900 & 15.66000 & 38.87900 & 0.05348 & 0.83748 & 2.07920 \\
\hline Gal & 18.69800 & 15.66000 & 38.92100 & 0.05348 & 0.83752 & 2.08156 \\
\hline Gal & 18.69800 & 15.66600 & 38.92600 & 0.05348 & 0.83784 & 2.08183 \\
\hline Gal & 18.68800 & 15.66000 & 38.91400 & 0.05351 & 0.83797 & 2.08230 \\
\hline Gal & 18.69500 & 15.66500 & 38.90900 & 0.05349 & 0.83792 & 2.08125 \\
\hline Gal & 18.69000 & 15.66000 & 38.90700 & 0.05350 & 0.83788 & 2.08170 \\
\hline Gal & 18.68900 & 15.66200 & 38.90900 & 0.05351 & 0.83803 & 2.08192 \\
\hline Gal & 18.68900 & 15.66000 & 38.91300 & 0.05351 & 0.83793 & 2.08213 \\
\hline Gal & 18.69600 & 15.67000 & 38.94900 & 0.05349 & 0.83815 & 2.08328 \\
\hline Gal & 18.69800 & 15.66900 & 38.93400 & 0.05348 & 0.83800 & 2.08225 \\
\hline Gal & 18.68600 & 15.66400 & 38.91200 & 0.05352 & 0.83827 & 2.08241 \\
\hline Gal & 18.68900 & 15.66300 & 38.91300 & 0.05351 & 0.83809 & 2.08213 \\
\hline Gal & 18.68600 & 15.66100 & 38.91400 & 0.05352 & 0.83811 & 2.08252 \\
\hline Gal & 18.70400 & 15.66900 & 38.96400 & 0.05346 & 0.83774 & 2.08319 \\
\hline Gal & 18.70600 & 15.66000 & 38.86800 & 0.05346 & 0.83716 & 2.07784 \\
\hline Gal & 18.73100 & 15.66200 & 38.76600 & 0.05339 & 0.83615 & 2.06962 \\
\hline Gal & 18.70300 & 15.63400 & 38.67900 & 0.05347 & 0.83591 & 2.06806 \\
\hline Gal & 18.71300 & 15.63500 & 38.69000 & 0.05344 & 0.83552 & 2.06755 \\
\hline Gal & 18.73500 & 15.65900 & 38.79200 & 0.05338 & 0.83582 & 2.07056 \\
\hline Gal & 18.72500 & 15.64500 & 38.76800 & 0.05340 & 0.83551 & 2.07039 \\
\hline
\end{tabular}




$\begin{array}{lllllll}\text { Gal } & 18.76600 & 15.69500 & 38.91200 & 0.05329 & 0.83635 & 2.07354 \\ \text { Gal } & 18.73800 & 15.66800 & 38.80000 & 0.05337 & 0.83616 & 2.07066 \\ \text { Gal } & 18.77300 & 15.69200 & 38.93200 & 0.05327 & 0.83588 & 2.07383 \\ \text { Gal } & 18.73600 & 15.66000 & 38.81100 & 0.05337 & 0.83582 & 2.07147 \\ \text { Gal } & 18.73800 & 15.66100 & 38.78700 & 0.05337 & 0.83579 & 2.06996 \\ \text { Gal } & 18.74000 & 15.66400 & 38.80400 & 0.05336 & 0.83586 & 2.07065 \\ \text { Gal } & 18.70700 & 15.66200 & 38.91300 & 0.05346 & 0.83723 & 2.08013\end{array}$




\section{Reference}

Barnes et al, 1975

Barnes et al, 1975

Barnes et al, 1975

Barnes et al, 1975

Barnes et al, 1975

Barnes et al, 1975

Barnes et al, 1975

Stos-Gale et al, 1996

Stos-Gale et al, 1996

Stos-Gale et al, 1996

Barnes et al, 1975

Barnes et al, 1975

OXALID unpublished data OXALID unpublished data

Stos-Gale et al, 1996

Stos-Gale et al, 1996

Barnes et al, 1974

Barnes et al, 1975

Barnes et al, 1975

Barnes et al, 1975

Barnes et al, 1975

Barnes et al, 1975

Barnes et al, 1976

Stos-Gale et al, 1996

Stos-Gale et al, 1996

Stos-Gale et al, 1996

Stos-Gale et al, 1996

Barnes et al, 1975

Stos-Gale et al, 1996

Stos-Gale et al, 1996

Stos-Gale et al, 1996

OXALID unpublished data

OXALID unpublished data

OXALID unpublished data

OXALID unpublished data

OXALID unpublished data

OXALID unpublished data

OXALID unpublished data

OXALID unpublished data

OXALID unpublished data

OXALID unpublished data

OXALID unpublished data

OXALID unpublished data

OXALID unpublished data

OXALID unpublished data

OXALID unpublished data

OXALID unpublished data

OXALID unpublished data

OXALID unpublished data

OXALID unpublished data

OXALID unpublished data

Wagner and Weisgerber, 1985

Wagner and Weisgerber, 1985

OXALID unpublished data

OXALID unpublished data

Wagner and Weisgerber, 1985

Wagner and Weisgerber, 1985

Wagner and Weisgerber, 1985 
Wagner and Weisgerber, 1985

Wagner and Weisgerber, 1985

Wagner and Weisgerber, 1985

Wagner and Weisgerber, 1985

Wagner and Weisgerber, 1985

Wagner and Weisgerber, 1985

Wagner and Weisgerber, 1985

Wagner and Weisgerber, 1985

Wagner and Weisgerber, 1985

Wagner and Weisgerber, 1985

Wagner and Weisgerber, 1985

OXALID unpublished data

OXALID unpublished data

OXALID unpublished data

OXALID unpublished data

OXALID unpublished data

OXALID unpublished data

OXALID unpublished data

OXALID unpublished data

OXALID unpublished data

OXALID unpublished data

OXALID unpublished data

OXALID unpublished data

OXALID unpublished data

OXALID unpublished data

OXALID unpublished data

OXALID unpublished data

OXALID unpublished data

OXALID unpublished data

OXALID unpublished data

OXALID unpublished data

OXALID unpublished data

OXALID unpublished data

OXALID unpublished data

OXALID unpublished data

OXALID unpublished data

OXALID unpublished data

OXALID unpublished data

OXALID unpublished data

Gale, 1998

Gale, 1998

Gale and Stos-Gale, 1981

Stos-Gale et al, 1996

Stos-Gale et al, 1996

OXALID unpublished data

OXALID unpublished data

OXALID unpublished data

Gale, 1998

Stos-Gale et al, 1996

Gale, 1998

Stos-Gale et al, 1996

Stos-Gale et al, 1996

Gale, 1998

Stos-Gale et al, 1996

Gale and Stos-Gale, 1981

OXALID unpublished data

OXALID unpublished data 
OXALID unpublished data

OXALID unpublished data

OXALID unpublished data

Stos-Gale et al, 1996

OXALID unpublished data

Gale, 1998

Gale, 1998

OXALID unpublished data

OXALID unpublished data

OXALID unpublished data

Stos-Gale et al, 1996

Gale, 1998

IGME

Gale and Stos-Gale, 1981

Stos-Gale et al, 1996

Stos-Gale et al, 1996

Stos-Gale et al, 1996

Stos-Gale et al, 1996

Stos-Gale et al, 1996

Stos-Gale et al, 1996

Stos-Gale et al, 1996

Stos-Gale et al, 1996

Stos-Gale et al, 1996

Stos-Gale et al, 1996

Stos-Gale et al, 1996

Stos-Gale et al, 1996

Stos-Gale et al, 1996

Stos-Gale et al, 1996

Stos-Gale et al, 1996

Stos-Gale et al, 1996

OXALID unpublished data

OXALID unpublished data

OXALID unpublished data

OXALID unpublished data

Stos-Gale et al, 1996

Stos-Gale et al, 1996

Stos-Gale et al, 1996

Stos-Gale et al, 1996

Stos-Gale et al, 1996

Stos-Gale et al, 1996

Stos-Gale et al, 1996

Stos-Gale et al, 1996

Stos-Gale et al, 1996

Stos-Gale et al, 1996

Stos-Gale et al, 1996

Stos-Gale et al, 1996

Gale and Stos-Gale, 1981

Gale and Stos-Gale, 1981

Stos-Gale et al, 1996

Stos-Gale et al, 1996

Stos-Gale et al, 1996

Stos-Gale et al, 1996

Stos-Gale et al, 1996

OXALID unpublished data

Stos-Gale et al, 1996

Stos-Gale et al, 1996

Stos-Gale et al, 1996

Stos-Gale et al, 1996

OXALID unpublished data 
Stos-Gale et al, 1996

Stos-Gale et al, 1996

OXALID unpublished data

OXALID unpublished data

OXALID unpublished data

OXALID unpublished data

OXALID unpublished data

OXALID unpublished data

OXALID unpublished data

OXALID unpublished data

OXALID unpublished data

OXALID unpublished data

OXALID unpublished data

OXALID unpublished data

OXALID unpublished data

OXALID unpublished data

OXALID unpublished data

OXALID unpublished data

OXALID unpublished data

OXALID unpublished data

OXALID unpublished data

OXALID unpublished data

OXALID unpublished data

OXALID unpublished data

OXALID unpublished data

OXALID unpublished data

OXALID unpublished data

OXALID unpublished data

OXALID unpublished data

Gale, 1998

Gale, 1998

OXALID unpublished data OXALID unpublished data

OXALID unpublished data

OXALID unpublished data

OXALID unpublished data

OXALID unpublished data

OXALID unpublished data

Gale, 1998

Gale, 1998

OXALID unpublished data

OXALID unpublished data

OXALID unpublished data

OXALID unpublished data

OXALID unpublished data

OXALID unpublished data

OXALID unpublished data

OXALID unpublished data

OXALID unpublished data

OXALID unpublished data

OXALID unpublished data

OXALID unpublished data

OXALID unpublished data

OXALID unpublished data

OXALID unpublished data

OXALID unpublished data

OXALID unpublished data

OXALID unpublished data

OXALID unpublished data 
OXALID unpublished data OXALID unpublished data

Gale, 1998

Gale, 1998

Gale, 1998

Gale, 1998

Gale, 1998

OXALID unpublished data

OXALID unpublished data

OXALID unpublished data

OXALID unpublished data

OXALID unpublished data

OXALID unpublished data

OXALID unpublished data

OXALID unpublished data

OXALID unpublished data

OXALID unpublished data

OXALID unpublished data

OXALID unpublished data

OXALID unpublished data

OXALID unpublished data

OXALID unpublished data

OXALID unpublished data

OXALID unpublished data

OXALID unpublished data

OXALID unpublished data

OXALID unpublished data

OXALID unpublished data

OXALID unpublished data

OXALID unpublished data

OXALID unpublished data

OXALID unpublished data

Asderaki et al, 2017

OXALID unpublished data

Frei, 1992

Frei, 1992

Frei, 1992

Frei, 1992

Frei, 1992

Frei, 1992

Frei, 1992

Frei, 1992

Frei, 1992

Frei, 1992

Frei, 1992

Frei, 1992

Frei, 1992

Frei, 1992

Frei, 1992

Frei, 1992

Frei, 1992

Frei, 1992

Nebel et al, 1991

Nebel et al, 1991

Nebel et al, 1991

Nebel et al, 1991

Kalogeropoulos et al, 1989

Wagner et al, 1986

Wagner et al, 1986 
Vavelidis, 1985

Wagner et al, 1986

Wagner et al, 1986

Frei, 1992

Kalogeropoulos et al,1989

Wagner et al, 1986

Wagner et al, 1986

Wagner et al, 1986

Frei, 1992

Frei, 1992

Stos-Gale et al, 1996

Stos-Gale et al, 1996

Stos-Gale et al, 1996

Stos-Gale et al, 1996

Stos-Gale et al, 1996

Stos-Gale et al, 1996

Stos-Gale et al, 1996

OXALID unpublished data

Stos-Gale et al, 1996

Stos-Gale et al, 1996

Stos-Gale et al, 1996

Stos-Gale et al, 1996

Stos-Gale et al, 1996

Stos-Gale et al, 1996

Frei, 1992

Frei, 1992

IGME Xanthi department IGME Xanthi department IGME Xanthi department IGME Xanthi department IGME Xanthi department

Frei, 1992

IGME Xanthi department

Frei, 1992

Frei, 1992

Frei, 1992

Frei, 1992

Frei, 1992

Frei, 1992

Frei, 1992

Frei, 1992

IGME Xanthi department IGME Xanthi department IGME Xanthi department IGME Xanthi department IGME Xanthi department IGME Xanthi department IGME Xanthi department IGME Xanthi department IGME Xanthi department IGME Xanthi department IGME Xanthi department IGME Xanthi department Frei, 1992

IGME Xanthi department IGME Xanthi department IGME Xanthi department

Frei, 1992

Frei, 1992 
Frei, 1992

Frei, 1992

Frei, 1992

IGME Xanthi department IGME Xanthi department IGME Xanthi department

IGME Xanthi department 


\begin{tabular}{|c|c|c|c|c|c|}
\hline & Mining Area & Subdistricts & Mining Activity & $\begin{array}{l}\text { Dating of surface } \\
\text { observed findings }\end{array}$ & Metallurgy \\
\hline \multirow{6}{*}{1} & \multirow{6}{*}{ Lavrion } & Ari-Dimoliaki-Manoutsos & Over 100 ancient shafts and adits & \multirow{6}{*}{$\begin{array}{l}\text { Prehistoric, Archaic, } \\
\text { Classical, Hellenistic, } \\
\text { Roman, Byzantine } \\
\text { period }\end{array}$} & \multirow{6}{*}{$\begin{array}{l}\text { Numerous metallurgical } \\
\text { establishments with } \\
\text { washeries, grinding stones, } \\
\text { furnace remains and slag } \\
\text { heaps }\end{array}$} \\
\hline & & Plaka & Over 14 modern shafts and adits & & \\
\hline & & Kamariza-Soureza & Over 130 ancient shafts and adits & & \\
\hline & & Botsari-Noria-Agrileza & Over 40 ancient shafts and adits & & \\
\hline & & Spitharopoussi-Megala Pefka & Over 50 ancient shafts and adits & & \\
\hline & & Sounion & Over 30 ancient shafts and adits & & \\
\hline \multirow{3}{*}{2} & \multirow{3}{*}{ South Euboea } & Gialpides & 2 ancient adits & \multirow{3}{*}{ Classical period } & \multirow{3}{*}{$\begin{array}{l}\text { Two metallurgical areas with } \\
\text { grinding stones, furnace } \\
\text { remains and slag heaps. }\end{array}$} \\
\hline & & Kallianou Valley & 11 modern and 2 ancient adits & & \\
\hline & & Schinodavli & 3 Ancient adits & & \\
\hline 3 & Central Euboea & Almyropotamos & $\begin{array}{c}3 \text { Modern shafts and } 2 \text { adits with ancient } \\
\text { horizontal parts }\end{array}$ & & No metallurgical remains \\
\hline \multirow{6}{*}{4} & \multirow{6}{*}{ Siphnos } & Ayios Sostis & Ancient and modern shafts and adits & \multirow{6}{*}{$\begin{array}{c}\text { Prehistoric, Archaic, } \\
\text { Roman, Byzantine } \\
\text { period }\end{array}$} & \multirow{6}{*}{$\begin{array}{l}\text { Three metallurgical areas } \\
\text { with grinding stones, furnace } \\
\text { remains and slag heaps. }\end{array}$} \\
\hline & & Agios Silvestros & Ancient and modern adits & & \\
\hline & & Voreini & Ancient and modern adits & & \\
\hline & & Kapsalos-Frase & Ancient and modern adits & & \\
\hline & & Xero Xylo & Ancient and modern shafts and adits & & \\
\hline & & Aspros Pyrgos & Modern adits and trenches & & \\
\hline 5 & Seriphos & Moutoula & 9 modern adits with ancient parts & & No metallurgical remains \\
\hline \multirow{2}{*}{6} & \multirow{2}{*}{ Melos } & Triades & 2 ancient open works & \multirow{2}{*}{$\begin{array}{c}\begin{array}{c}\text { Prehistoric, Roman } \\
\text { period }\end{array} \\
\end{array}$} & \multirow{2}{*}{ No metallurgical remains } \\
\hline & & Katsimouti & 1 ancient adit & & \\
\hline 7 & Syros & Rozos & 1 ancient adit and 1 modern shaft & Prehistoric times & No metallurgical remains \\
\hline 8 & Kythnos & Agios Dimitrios & 1 ancient adit and 1 modern shaft & & $\begin{array}{l}\text { Slags and furnace remains } \\
\text { from copper smelting }\end{array}$ \\
\hline \multirow{3}{*}{9} & \multirow{3}{*}{ Antiparos } & Agios Georgios & 2 modern adits and 1 modern shaft & & \multirow{3}{*}{ No metallurgical remains } \\
\hline & & Prassovounia & 4 modern adits & & \\
\hline & & Monastiria & Modern adits with ancient parts & & \\
\hline 10 & Polyaigos & Tris Panagies & Modern adits & & No metallurgical remains \\
\hline 11 & Anaphi & Kandakospilia/ Doumbaria/Lagada & Modern adits & & No metallurgical remains \\
\hline \multirow{2}{*}{12} & \multirow{2}{*}{ Hymettus } & Agios loannis & 3 modern adits and 1 modern shaft & & \multirow{2}{*}{ No metallurgical remains } \\
\hline & & Kamini & 2 modern adits & & \\
\hline \multirow{2}{*}{13} & \multirow{2}{*}{ Pelion } & Agios Konstantinos & 5 modern adits and 1 ancient adit & \multirow{2}{*}{ Roman period } & No metallurgical remains \\
\hline & & Xourichti & Ancient adit & & No metallurgical remains \\
\hline 14 & Lesbos & Argenos (Megala Therma) & Modern adits & & No metallurgical remains \\
\hline 15 & Samothrace & Megalo Akrotiri & 2 modern adits & & No metallurgical remains \\
\hline & & Olympias & Over 20 ancient shafts and 2 adits & Prehistoric, & \\
\hline 16 & NF Chalkidiki & Madem Lakkos & 1 ancient adit & Hellenistic, Roman, & orindino stones furnace \\
\hline 10 & TVE CIIIKIUIKI & Mavres Petres & 2 ancient adits & Byzantine, Ottoman & remainc and clag heance \\
\hline & & \begin{tabular}{|l} 
Piavitsa \\
\end{tabular} & 1 ancient adit & period & \\
\hline & & Akropoli & 1 ancient adit with modern parts & & \\
\hline & & Vouves & Modern adits & Prehistoric, Archaic, & Metallurgical areas with \\
\hline 17 & Thasos & Kourlou & 1 ancient adit & Hellenistic, Roman & grinding stones, furnace \\
\hline & & Sotiros & Modern adits and 1 ancient adit & period & remains and slag heaps. \\
\hline & & Marlou & Modern adits with ancient parts & & \\
\hline & & Koulachli & 2 ancient adits & & $\left.\right|_{\text {TMin motall } \text {, rriral arasc in }}$ \\
\hline
\end{tabular}




\begin{tabular}{|c|c|c|c|c|c|}
\hline \multirow[t]{2}{*}{18} & \multirow[t]{2}{*}{ Kroussia } & Agios Markos & Modern shaft & & \multirow{2}{*}{$\begin{array}{l}\text { gvu norinding stones, furnace } \\
\text { remains and slag heaps. }\end{array}$} \\
\hline & & Vathi & 6 ancient adits & & \\
\hline 19 & Angistron & Agios Konstantinos & Modern and ancient adits and shafts & Hellenistic period & $\begin{array}{l}\text { Two metallurgical areas with } \\
\text { grinding stones, furnace } \\
\text { remains and slag heaps. }\end{array}$ \\
\hline \multirow{4}{*}{20} & \multirow{4}{*}{ Pangaeon } & Agia Triada & 3 ancient adits & \multirow{4}{*}{$\begin{array}{c}\text { Hellenistic, } \\
\text { Byzantine, Ottoman } \\
\text { period }\end{array}$} & \multirow{4}{*}{$\begin{array}{l}\text { Nine metallurgical areas with } \\
\text { grinding stones, furnace } \\
\text { remains and slag heaps. }\end{array}$} \\
\hline & & Nikisiani & 5 ancient and 3 modern adits & & \\
\hline & & Trikorfo-Avgo-Mavrokorfi & 6 ancient adits & & \\
\hline & & Ofrynio & 3 ancient adits & & \\
\hline \multirow{8}{*}{21} & \multirow{8}{*}{ Palaea Kavala } & Kryoneri-Zygos & 7 ancient adits and 2 shafts & \multirow{8}{*}{ Roman period } & \multirow{8}{*}{ Slags and furnace remains } \\
\hline & & Garizo Lofos & 4 ancient adits & & \\
\hline & & Mandra Kari & 3 ancient adits & & \\
\hline & & Kokkala & 2 ancient adits & & \\
\hline & & Giolia & 1 ancient adit & & \\
\hline & & Chalkero & 2 ancient adit & & \\
\hline & & Lefki & 1 ancient adit & & \\
\hline & & Petropigi & 1 ancient adit & & \\
\hline 22 & Thermes & & 3 modern adits & & No metallurgical remains \\
\hline 23 & Sappes & & Modern adits & & No metallurgical remains \\
\hline 24 & Kirki & & Modern adits & & No metallurgical remains \\
\hline 25 & Aisymi & & 2 modern adits & & No metallurgical remains \\
\hline 26 & Neda & & 1 modern adit and 1 of unidentified age & & No metallurgical remains \\
\hline 27 & Pefka & & 1 adit of unidentified age & & No metallurgical remains \\
\hline
\end{tabular}


Event

Aegean galenas (this study)

Aegean galenas (all data)

3

Iberian galenas (Millot et al., in press)

$\begin{array}{llllll}T_{\text {mod }}(\mathrm{Ma}) & s & \mu & s & \kappa\end{array}$

$\begin{array}{lrrrrr}1 & 35 & 9 & 9.85 & 0.04 & 3.88 \\ 2 & 97 & 34 & 9.89 & 0.06 & 3.94 \\ 3 & 154 & 12 & 9.92 & 0.04 & 3.97 \\ 4 & 190 & 13 & 9.94 & 0.01 & 3.97 \\ 5 & 354 & 10 & 9.92 & 0.05 & 3.99\end{array}$

1

2

3

4

5

1

2

3

4

5
31

77

107

198

403

90

185

313

395

613

27

39

39

12

76

34

26

41

40

42
9.89

9.8

9.89

9.91

9.95

9.85

9.78

9.92

9.77

9.89
0.06

0.02

0.07

0.04

0.11

0.06

0.23

0.12

0.12

0.2
3.89

3.95

3.95

3.98

4.01

3.96

3.95

4.04

3.98

4.04 


$\begin{array}{rr}0.03 & 42 \\ 0.04 & 79 \\ 0.03 & 22 \\ 0.07 & 7 \\ 0.01 & 6 \\ & \\ 0.04 & 220 \\ 0.04 & 32 \\ 0.04 & 163 \\ 0.1 & 4 \\ 0.03 & 25 \\ & \\ 0.05 & 80 \\ 0.07 & 29 \\ 0.06 & 44 \\ 0.05 & 237 \\ 0.07 & 74\end{array}$




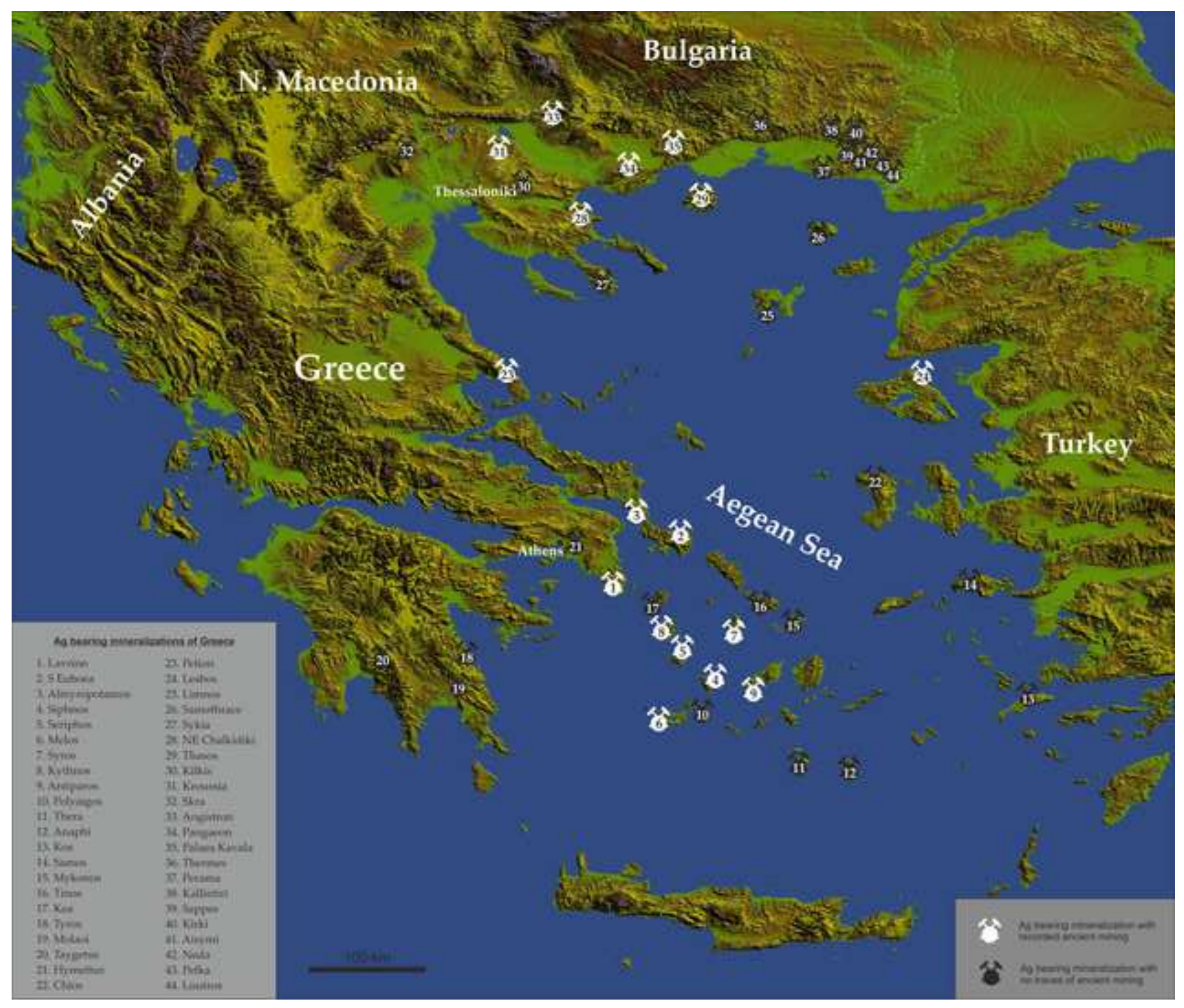




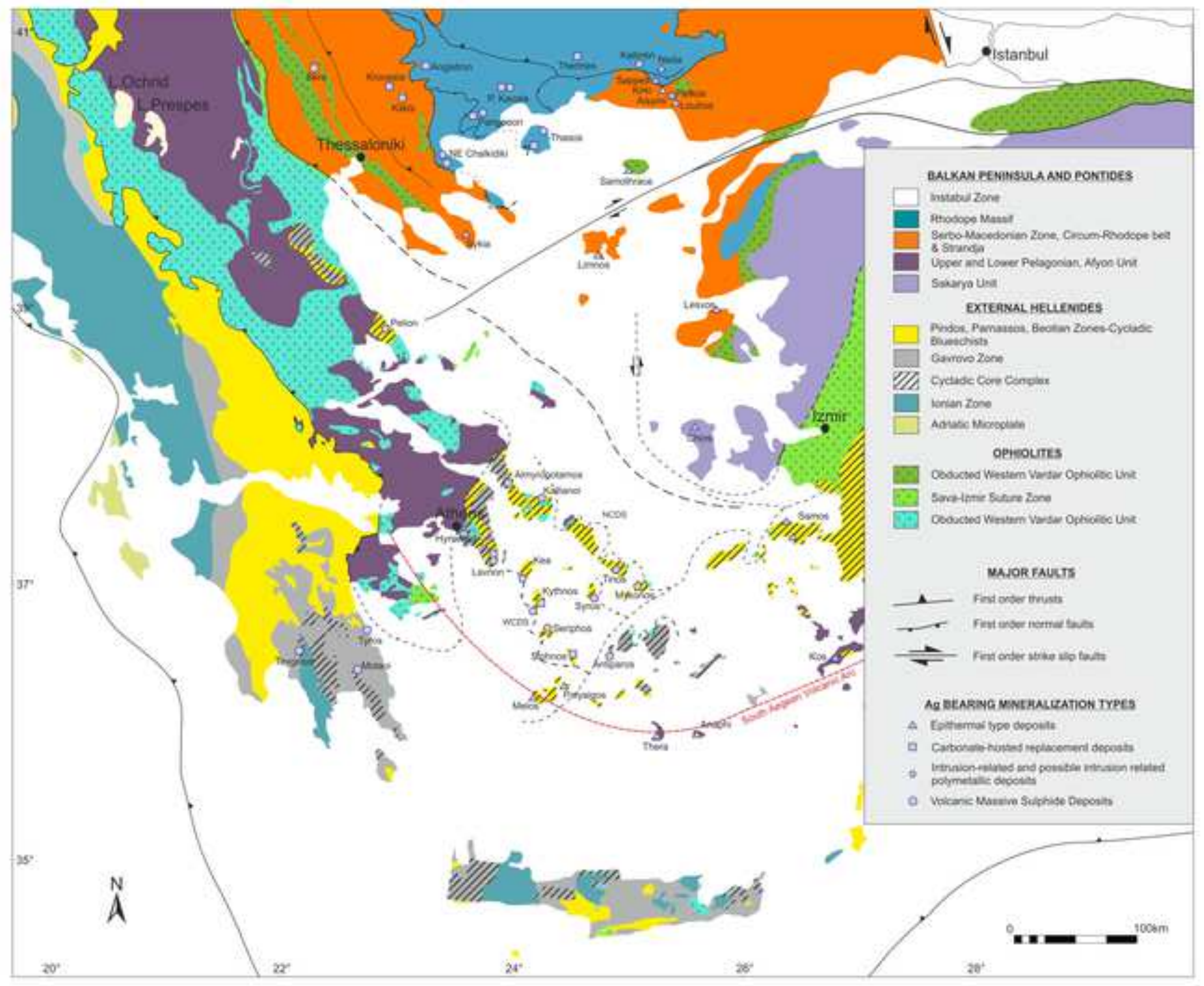



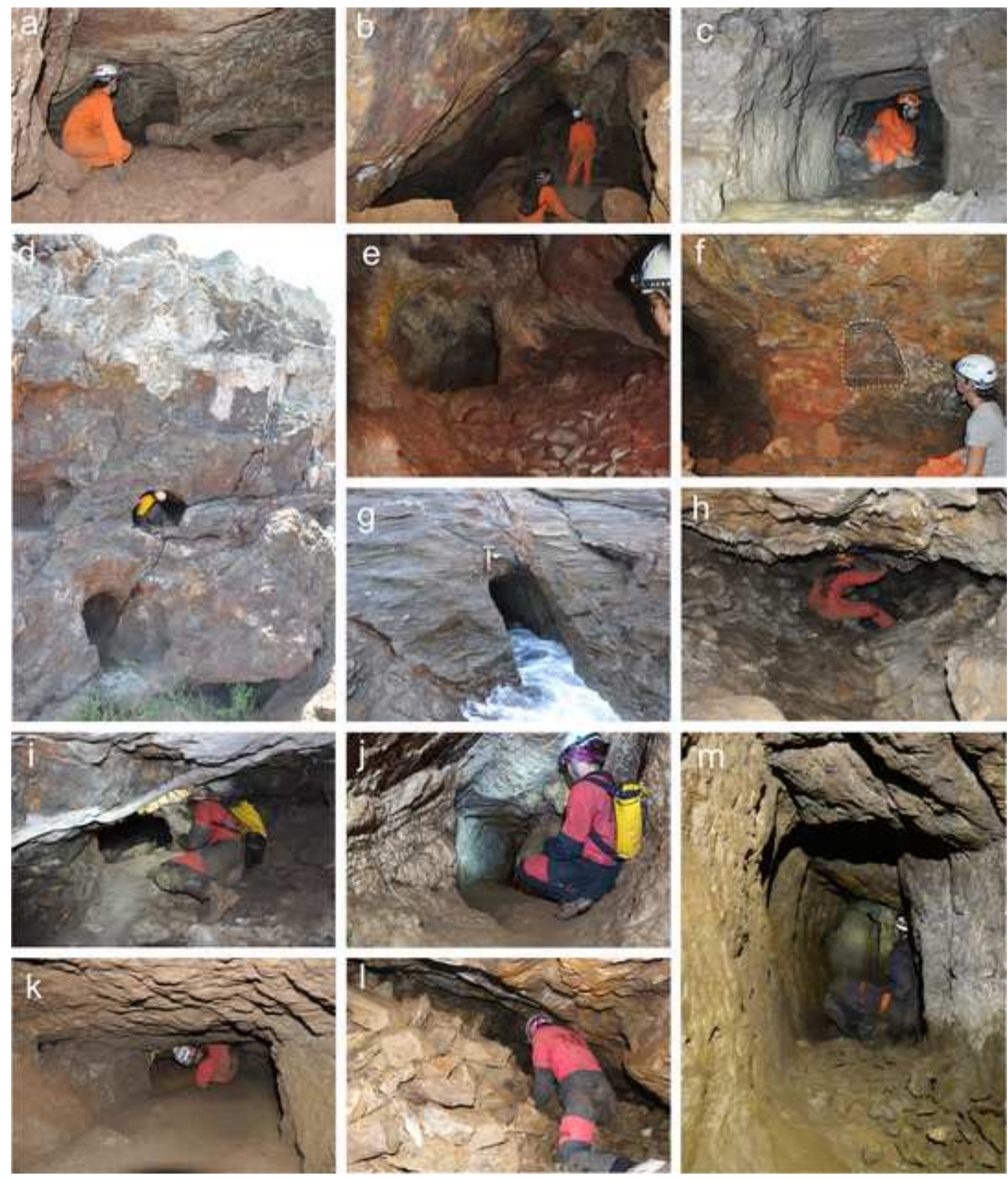


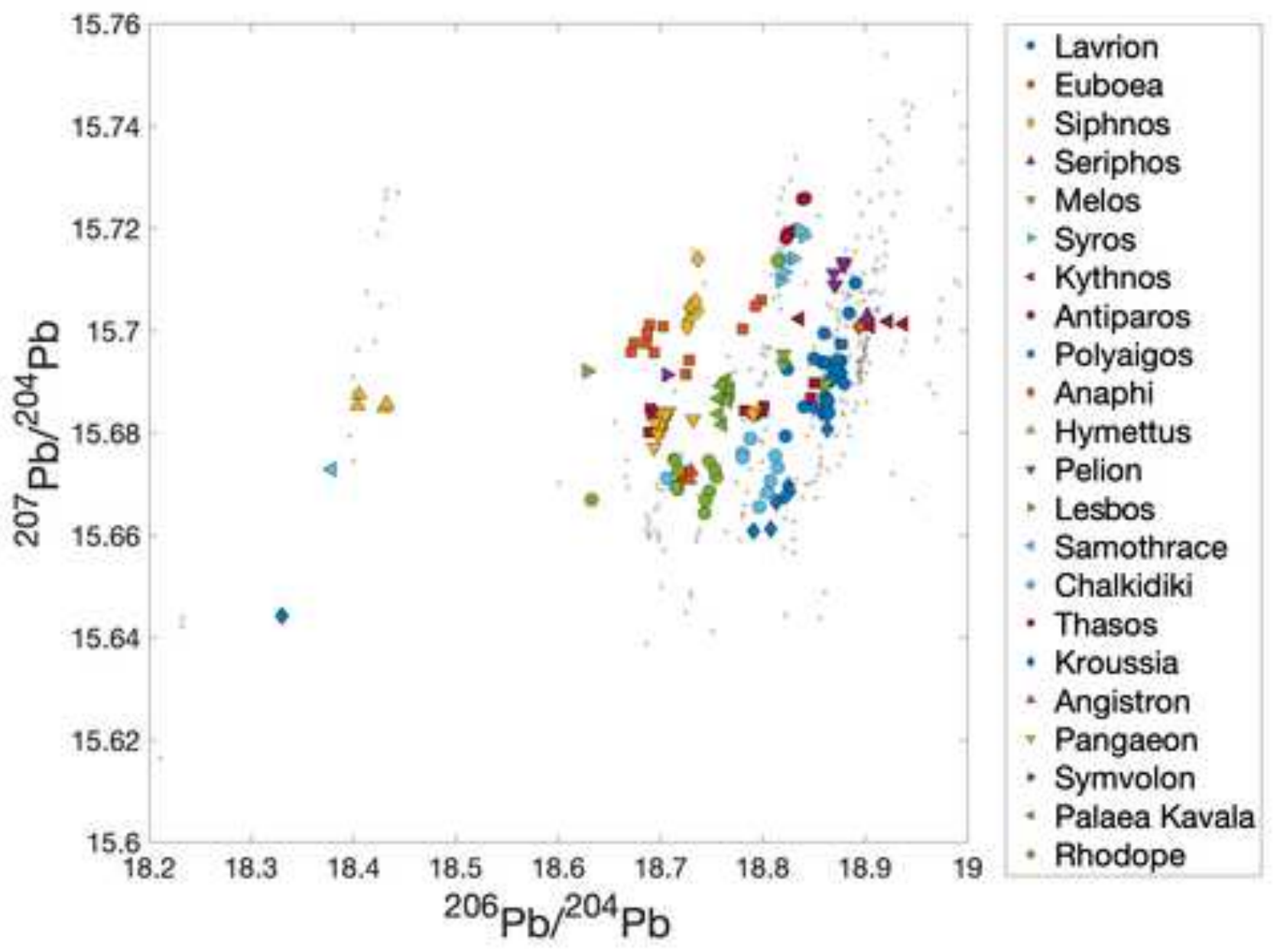




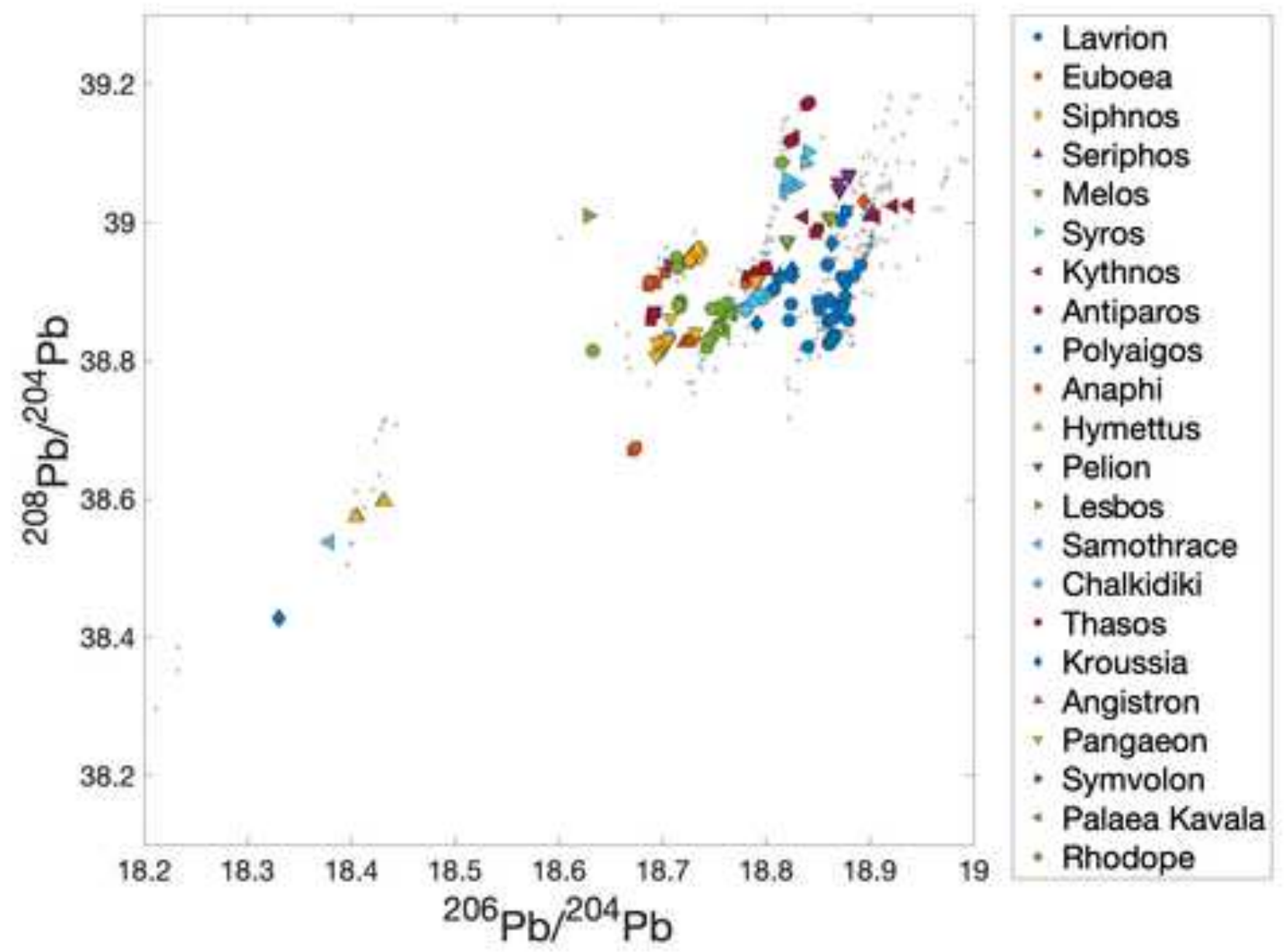




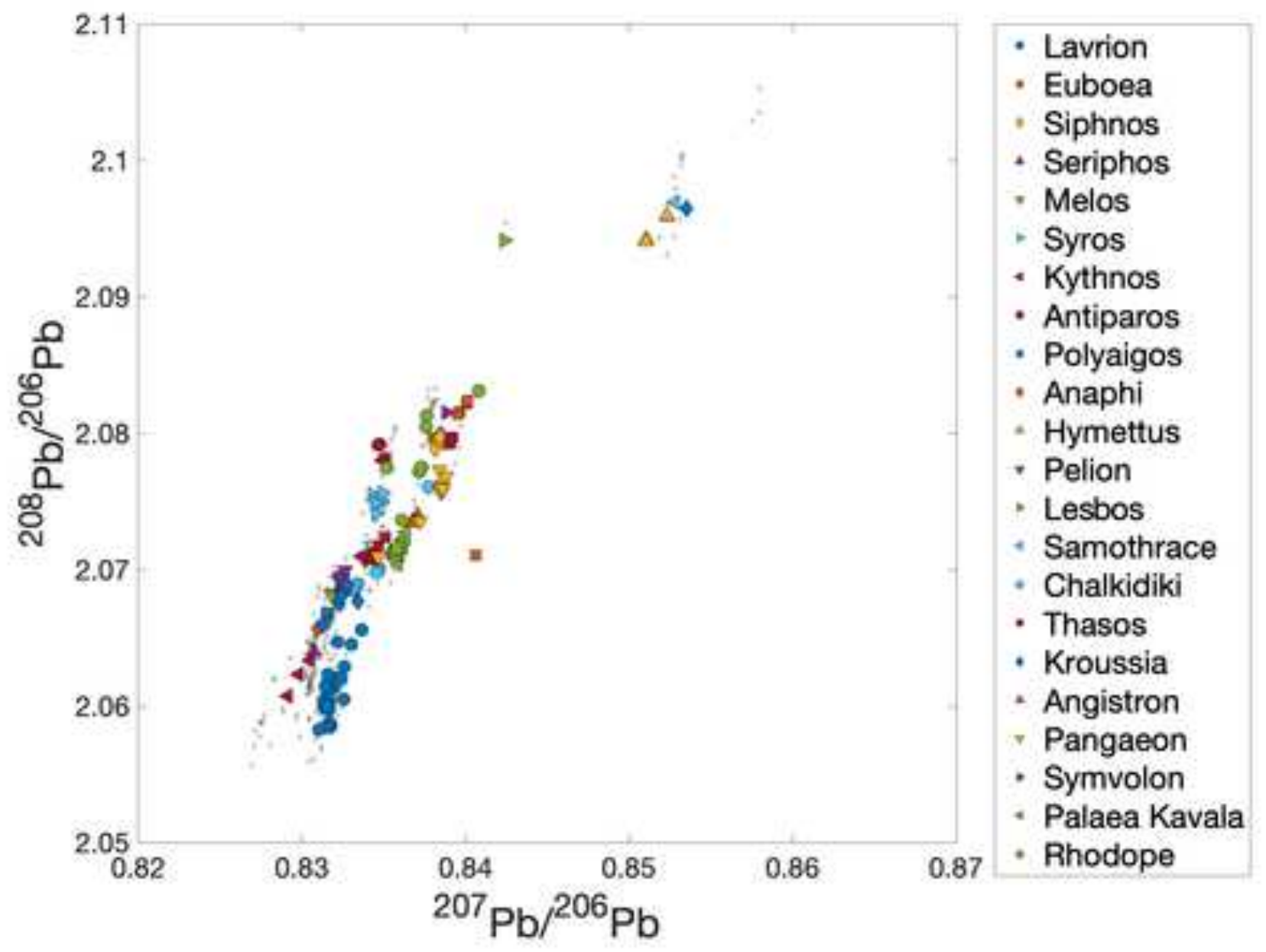




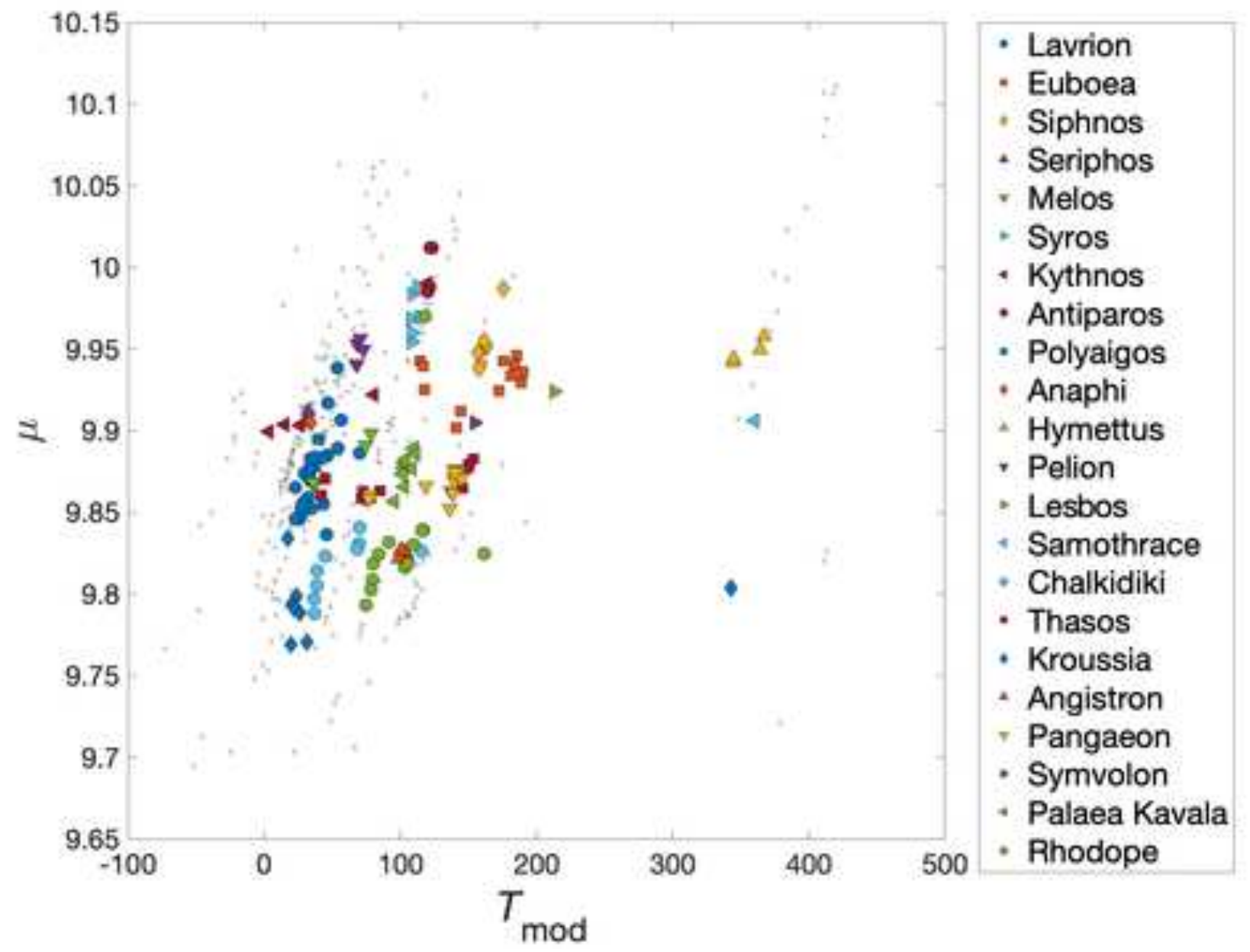




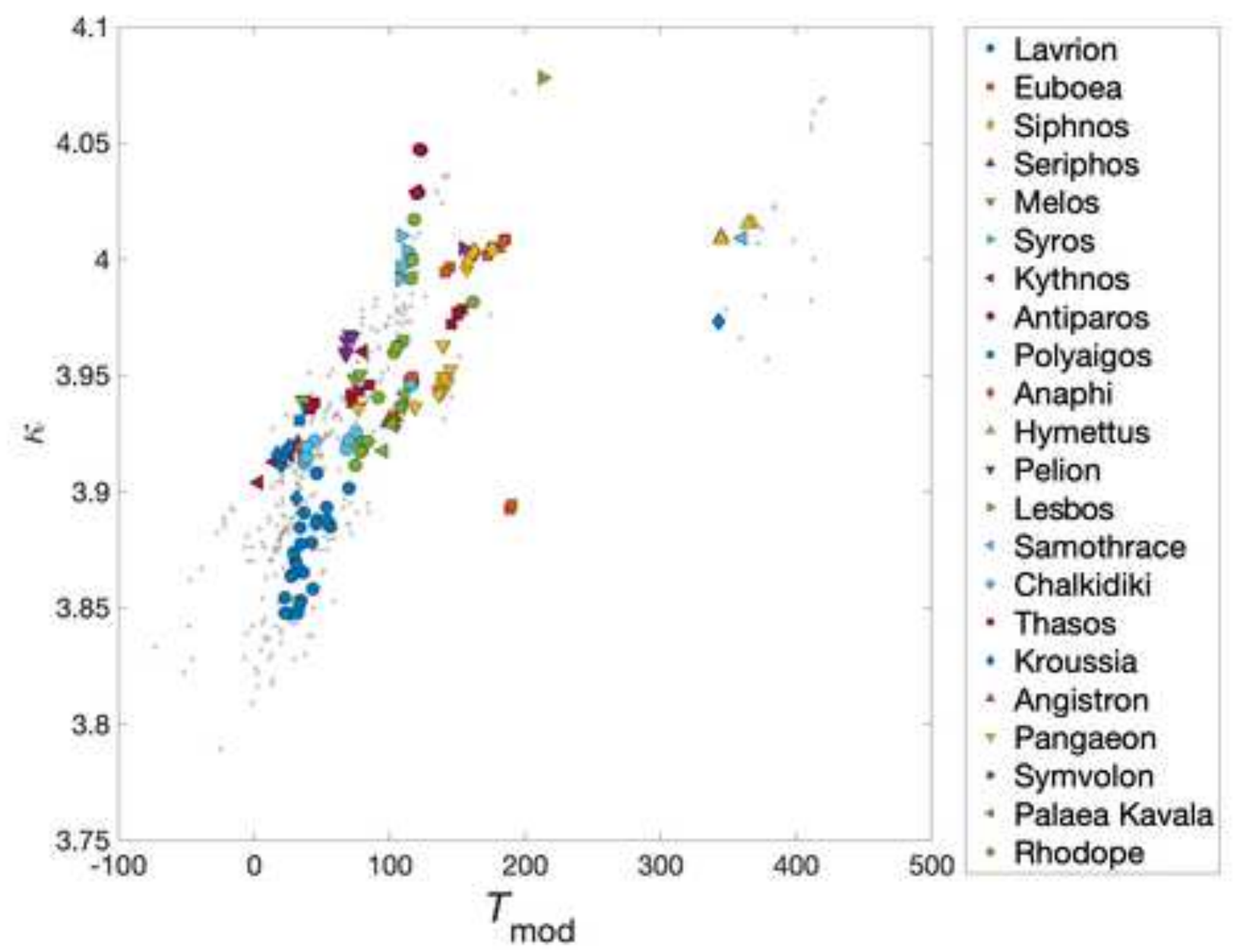



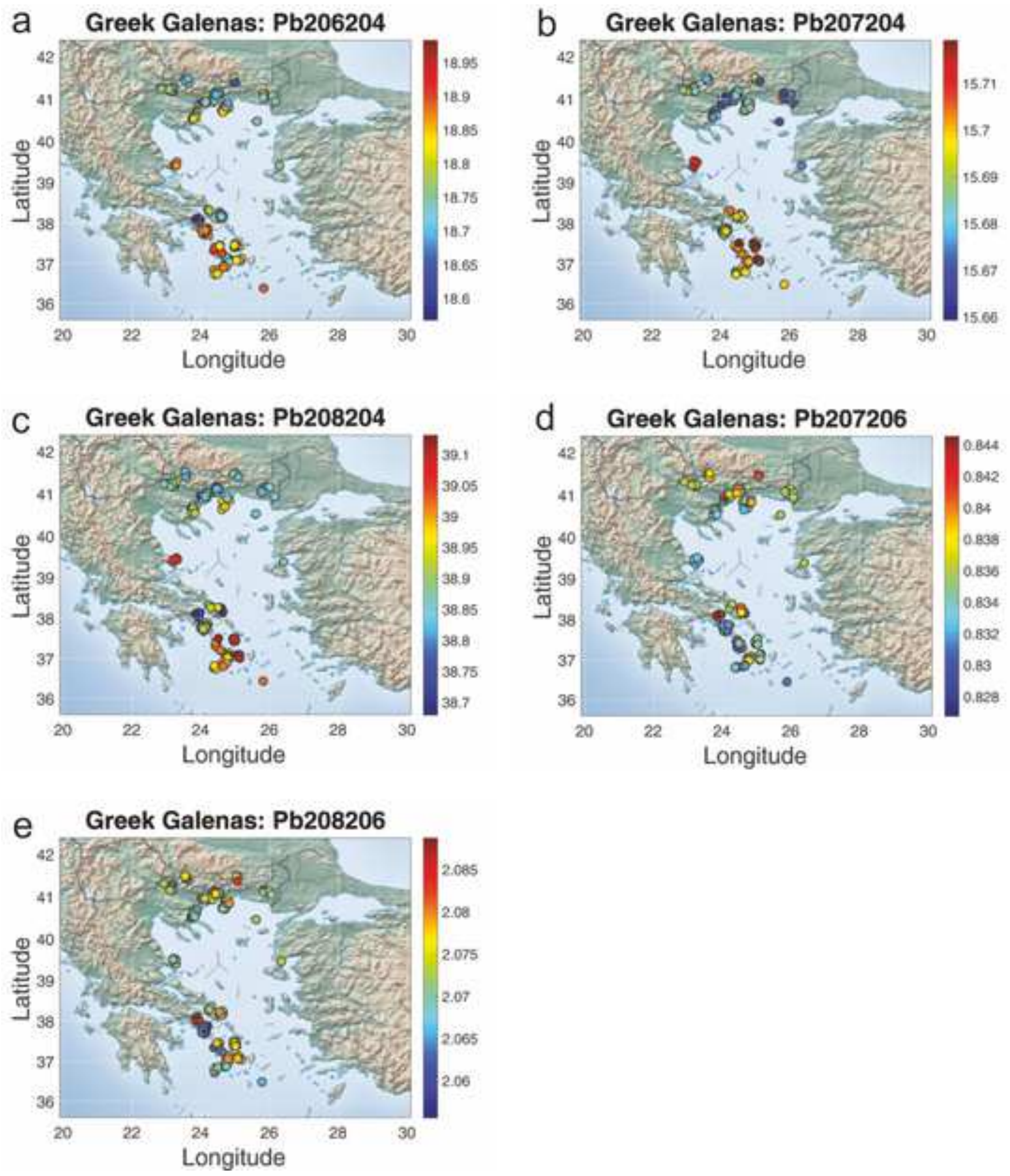

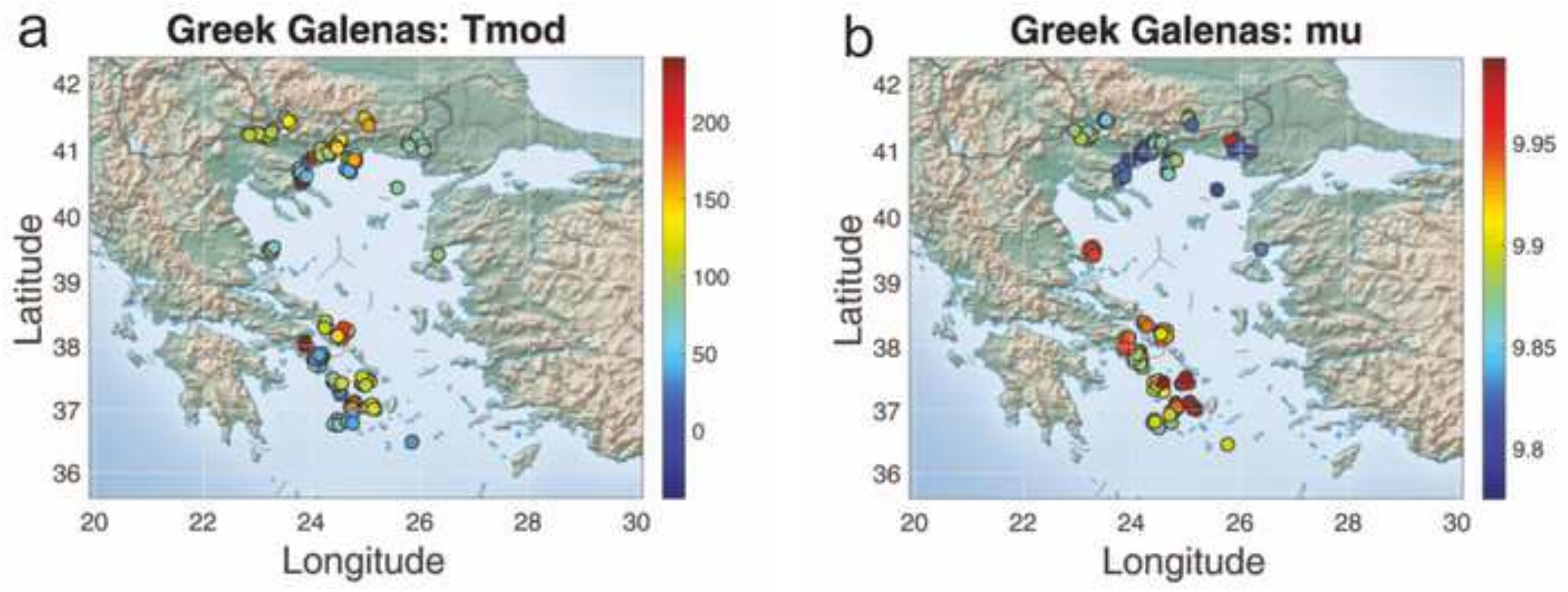

C Greek Galenas: kappa

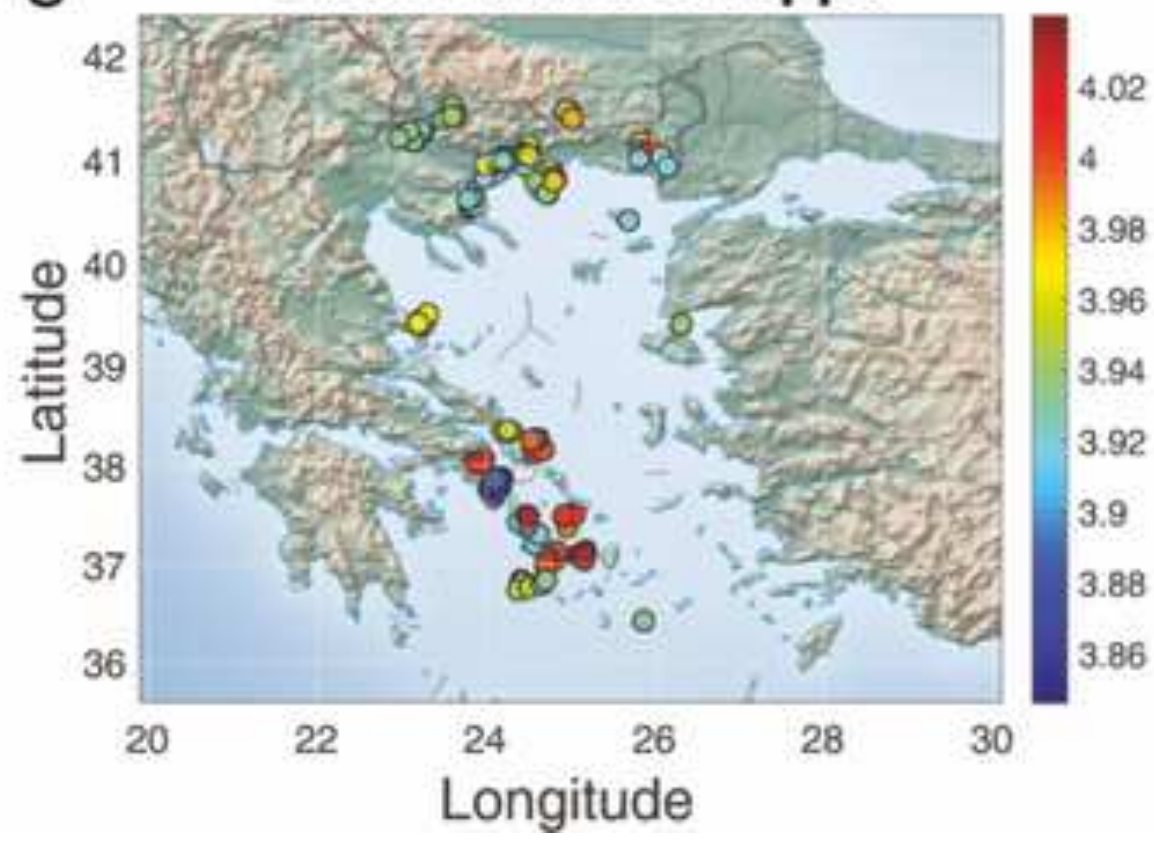




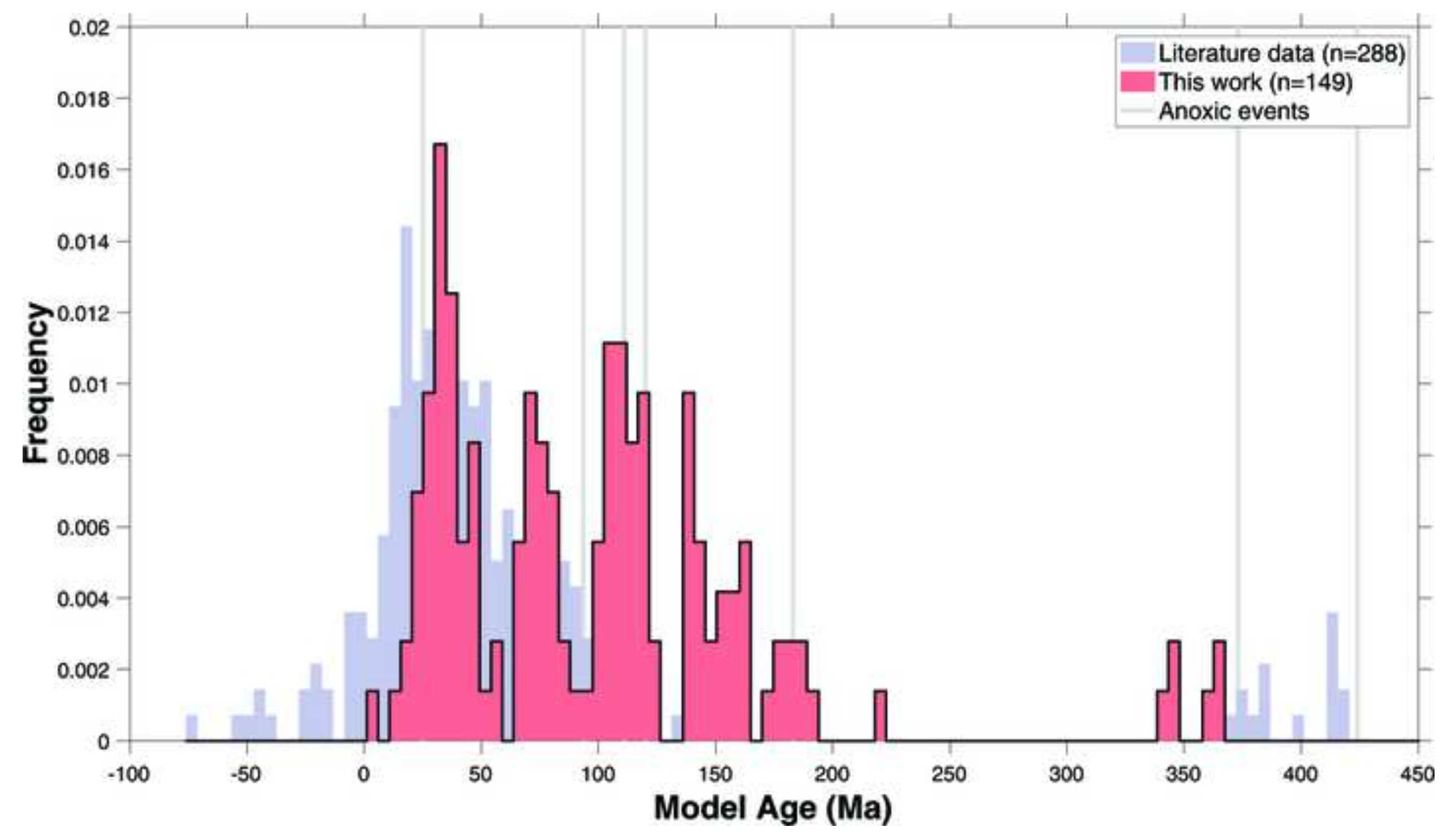

